Prepared for the U.S. Department of Energy under Contract DE-AC05-76RL01830

\title{
Renewable Energy Opportunities at Fort Polk, Louisiana
}
AE Solana
WJ Gorrissen
AC Orrell
JR Hand
BK Boyd
MR Weimar
BJ Russo
JA Horner
JL Williamson

RJ Nesse, Project Manager

December 2010

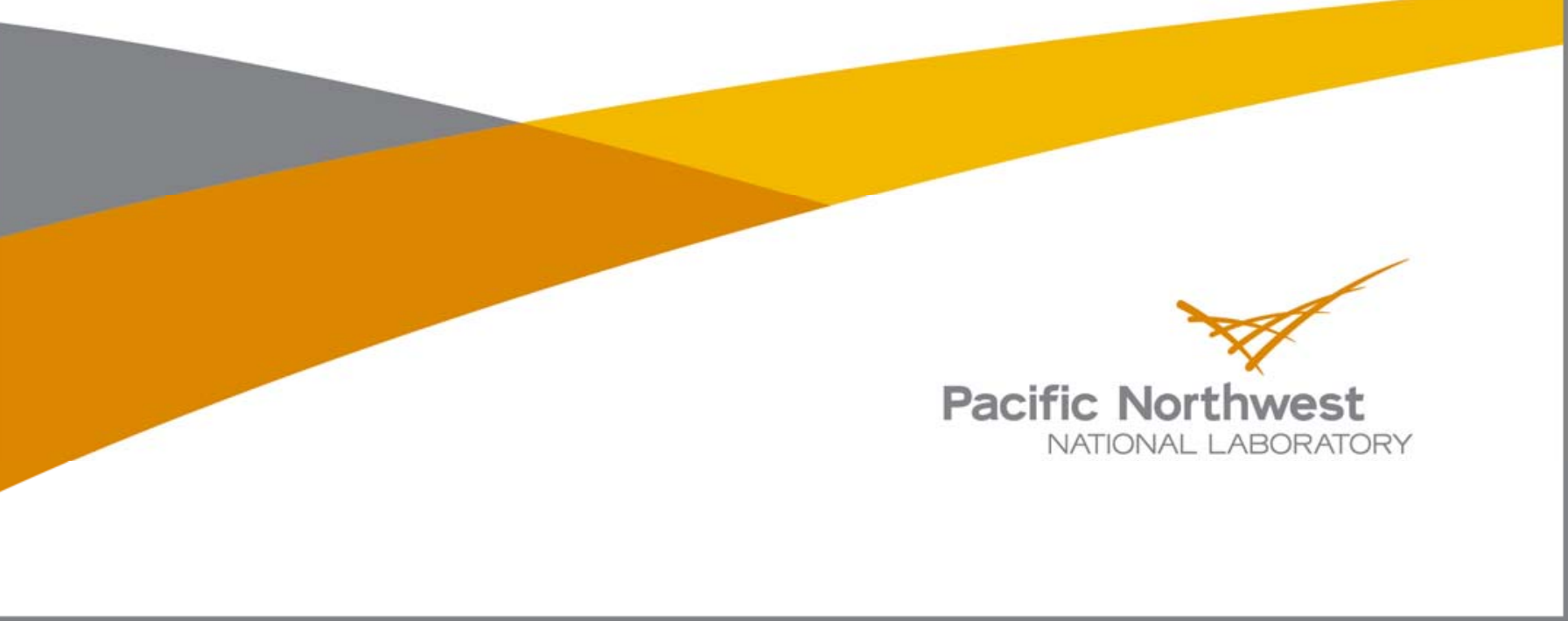




\title{
DISCLAIMER
}

This report was prepared as an account of work sponsored by an agency of the United States Government. Neither the United States Government nor any agency thereof, nor Battelle Memorial Institute, nor any of their employees, makes any warranty, express or implied, or assumes any legal liability or responsibility for the accuracy, completeness, or usefulness of any information, apparatus, product, or process disclosed, or represents that its use would not infringe privately owned rights. Reference herein to any specific commercial product, process, or service by trade name, trademark, manufacturer, or otherwise does not necessarily constitute or imply its endorsement, recommendation, or favoring by the United States Government or any agency thereof, or Battelle Memorial Institute. The views and opinions of authors expressed herein do not necessarily state or reflect those of the United States Government or any agency thereof.

\author{
PACIFIC NORTHWEST NATIONAL LABORATORY \\ operated by \\ BATTELLE \\ for the \\ UNITED STATES DEPARTMENT OF ENERGY \\ under Contract DE-AC05-76RL01830
}

Printed in the United States of America
Available to DOE and DOE contractors from the Office of Scientific and Technical Information,
P.O. Box 62, Oak Ridge, TN 37831-0062;
ph: (865) 576-8401
fax: $(865)$ 576-5728
email: reports@adonis.osti.gov

\begin{abstract}
Available to the public from the National Technical Information Service, U.S. Department of Commerce, 5285 Port Royal Rd., Springfield, VA 22161 ph: (800) 553-6847 fax: $(703) 605-6900$ email: orders@ntis.fedworld.gov online ordering: http://www.ntis.gov/ordering.htm
\end{abstract}

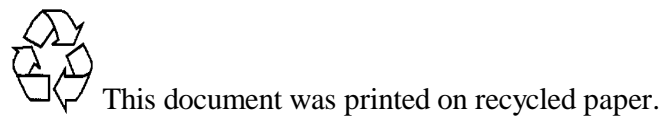




\section{Renewable Energy Opportunities at Fort Polk, Louisiana}

$\begin{array}{lll}\text { AE Solana } & \text { WJ Gorrissen } & \text { JR Hand } \\ \text { BK Boyd } & \text { AC Orrell } & \text { BJ Russo } \\ \text { JA Horner } & \text { MR Weimar } & \text { JL Williamson } \\ \text { RJ Nesse, Project Manager } & \end{array}$

December 2010

Prepared for

the U.S. Army Installation Management Command Headquarters under Contract DE-AC05-76RL01830

Related Services

Pacific Northwest National Laboratory

Richland, Washington 99352 


\section{Executive Summary}

This document provides an overview of renewable resource potential at Fort Polk, based primarily upon analysis of secondary data sources supplemented with limited onsite evaluations. This effort focuses on grid-connected generation of electricity from renewable energy sources and also on ground-source heat pumps for heating and cooling buildings. The effort was funded by the U.S. Army Installation Management Command (IMCOM) as follow-on to the 2005 Department of Defense (DoD) Renewables Assessment. The site visit to Fort Polk took place on February 16, 2010.

At this time, the only renewable technology that shows practical and economic potential at Fort Polk is a waste-to-energy plant consuming regional municipal solid waste. A biomass plant using wood waste shows marginal economics, but the feedstock is likely not available. There is also interest in developing geopressured-geothermal power from existing nearby gas wells. Project feasibility is based on installation-specific resource availability and energy costs as well as detailed economic analysis based on accepted life-cycle cost methods (Appendix A).

\section{Waste-to-Energy}

There is sufficient municipal solid waste in the area to build an economic waste-to-energy plant on Fort Polk. There are three landfills within 60 miles of Fort Polk that collect approximately 556,000 tons per year, which is expected to remain constant in the future. Some of this waste should be available for energy generation, with savings-to-investment ratios ranging from 1.1 to 1.8 and internal rates of return ranging from $8 \%$ to almost $15 \%$, depending on the size of the plant and technology used (combustion or gasification). Further details can be found in Appendix B.

\section{Geothermal Power}

There is interest in exploring geopressured-geothermal resources on Fort Polk. Analysis of geopressured-geothermal resources falls out of the scope of this assessment, but it could provide a path to economic geothermal power production. It is recommended that Fort Polk work with the U.S. Department of Energy (DOE) and DoD to further investigate the potential for geopressured-geothermal energy generation on and near the installation. See Appendix C for more details.

\section{Other Renewable Resources}

Other renewable technologies did not prove to be cost-effective under current conditions and assumptions. Other biomass resources (including crop residues, animal waste, dedicated crops, regional wood waste, mill residue, landfill gas, and wastewater treatment plant sludge) were found to be too scarce in the Fort Polk area or too expensive to transport to consider a generation project (Appendix B). Geothermal power generation requiring new wells to be drilled was found to be a poor economic option (Appendix C). Ground-source heat pump projects were also uneconomic (Appendix D). Solar projects are not likely to be cost-effective in the near future either, requiring an electricity cost of about $33 \phi / \mathrm{kWh}$ to generate a $10 \%$ internal rate of return (IRR) (Appendix E). The wind resource at Fort Polk is not sufficient for an economic wind 
project (Appendix F). With the average wind speed of $4.1 \mathrm{~m} / \mathrm{s}$, electricity would cost $57 \notin / \mathrm{kWh}$ with a $10 \%$ IRR.

Renewable resources with at least some potential for being economic are summarized in Table 1. If Fort Polk were to develop a waste-to-energy project with all area waste, it could provide about 305 GWh of electricity, or 158\% of the FY 2009 electrical consumption at Fort Polk. Increasing the use of renewable energy makes sense for the Army. The goal of this report is to help Army personnel make sense of renewable energy at Fort Polk.

Table 1: Summary of Promising Renewable Energy Projects at Fort Polk

\begin{tabular}{|c|c|c|c|c|c|c|c|c|}
\hline & $\begin{array}{l}\text { Renewable } \\
\text { Resource and } \\
\text { Technology }\end{array}$ & $\begin{array}{l}\text { Resource } \\
\text { Estimate }\end{array}$ & $\begin{array}{l}\text { Earliest } \\
\text { Output }\end{array}$ & Figures of Merit & $\begin{array}{c}\text { Financing } \\
\text { Mechanisms } \\
\text { Evaluated }\end{array}$ & $\begin{array}{l}\text { Location-- } \\
\text { Requirements }\end{array}$ & Key Assumptions & $\begin{array}{l}\text { Next Steps } \\
\text { Comments }\end{array}$ \\
\hline 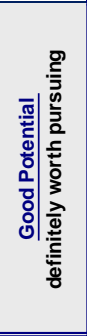 & \begin{tabular}{||c} 
Municipal Waste- \\
to-Energy Plant \\
using Combustion \\
or Gasification \\
Technologies
\end{tabular} & $\begin{array}{c}10-41 \mathrm{MW} \\
\text { (using Polk, } \\
\text { Timberlane, } \\
\text { Sabine Parish, } \\
\text { or Jefferson } \\
\text { Davis Parish LF } \\
\text { MSW) }\end{array}$ & 2012 & $\begin{array}{c}\text { ECIP scenario: 0.9- } \\
1.5 \text { SIR, 9.6-15.8 } \\
\text { year payback at } \\
6.74 \Phi / k W h \\
\\
\text { IPP scenario: } 6.7- \\
12.7 \% \text { IRR at } \\
6.74 \mathbb{\$} / \mathrm{kWh} \\
\\
\text { (function of } \\
\text { technology and } \\
\text { plant size) } \\
\end{array}$ & $\begin{array}{c}\text { ECIP } \\
\text { IPP }\end{array}$ & $\begin{array}{l}\text { A 5-acre site near } \\
\text { major roads, a utility } \\
\text { substation, water, } \\
\text { sewage, and an } \\
\text { appropriate industrial } \\
\text { infrastructure, plus } \\
\text { feedstock storage } \\
\text { space. }\end{array}$ & $\begin{array}{c}\text { MSW available for WTE } \\
\text { plant, and can be brought } \\
\text { on site. } \\
\text { Plant location can be } \\
\text { secured on Fort Polk. } \\
\text { Tipping fees of } \$ 20- \\
\text { 30/ton available with } \\
\text { MSW delivery to plant. }\end{array}$ & $\begin{array}{l}\text { Confirm waste } \\
\text { availability and tipping } \\
\text { fees. Economics are } \\
\text { highly dependent upon } \\
\text { tipping fee available } \\
\text { from waste providers. }\end{array}$ \\
\hline 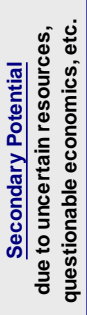 & $\begin{array}{l}\text { Geopressured- } \\
\text { Geothermal } \\
\text { Generation Plant }\end{array}$ & Unknown & Unknown & Unknown & $\begin{array}{l}\text { None (out of } \\
\text { assessment } \\
\text { scope) }\end{array}$ & $\begin{array}{c}\text { Near oil or gas wells, } \\
\text { and a utility } \\
\text { substation. }\end{array}$ & $\begin{array}{l}\text { Funding for exploration } \\
\text { available through DOE } \\
\text { and/or DoD. There is } \\
\text { significant developer } \\
\text { interest for development } \\
\text { on or near Fort Polk. }\end{array}$ & $\begin{array}{c}\text { There is likely potential } \\
\text { for energy generation, } \\
\text { but the resource must } \\
\text { be explored. } \\
\text { Consider } \\
\text { environmental impacts. } \\
\text { Confirm availability of } \\
\text { proposed DOE and } \\
\text { DoD funding. }\end{array}$ \\
\hline
\end{tabular}

SIR $=$ savings-to-investment ratio

ECIP $=$ Energy Conservation Investment Program

IPP $=$ independent power producer

UESC $=$ Utility Energy Services Contract

$\mathrm{ESPC}=$ Energy Savings Performance Contract

$\mathrm{MSW}=$ municipal solid waste

$\mathrm{WTE}=$ waste-to-energy 


\section{Table of Contents}

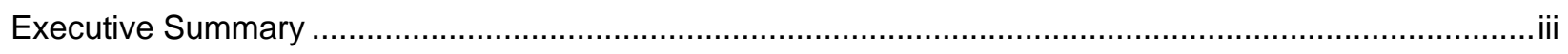

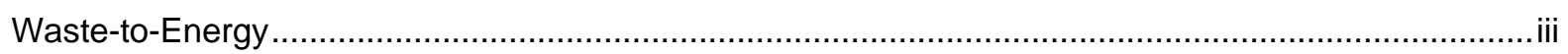

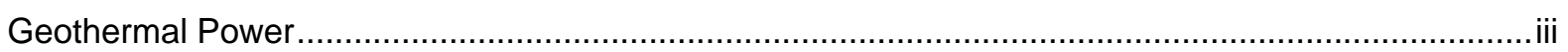

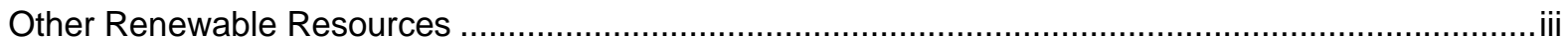

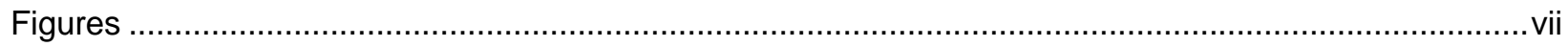

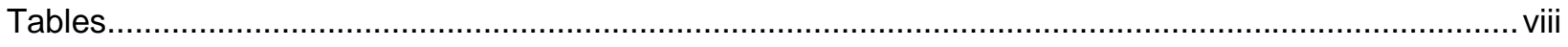

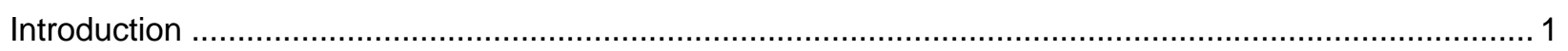

Overview of Federal and DoD Renewable Requirements ................................................................ 2

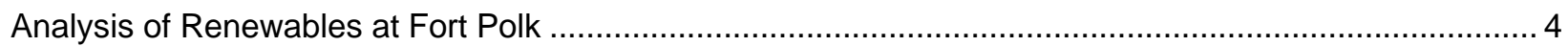

Approach for Identifying, Analyzing, and Implementing Renewable Energy Projects ....................... 4

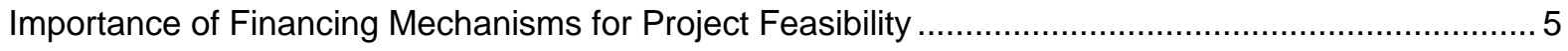

The Political and Economic Environment for Renewables at Fort Polk ........................................... 6

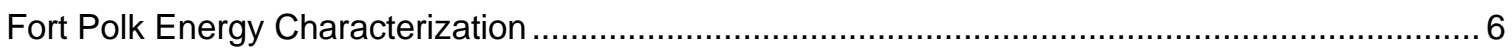

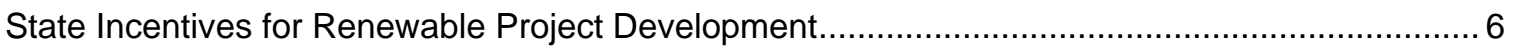

Federal Incentives for Renewable Project Development......................................................... 6

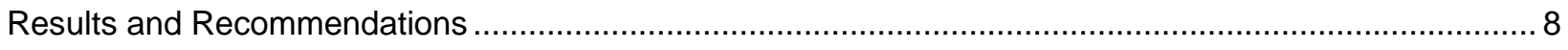

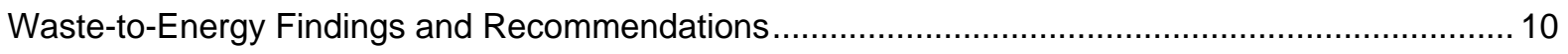

Geothermal Power Plant Findings and Recommendations ...................................................... 11

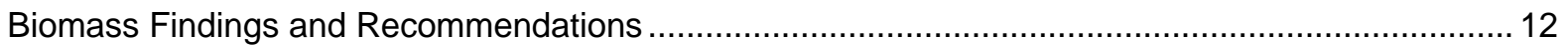

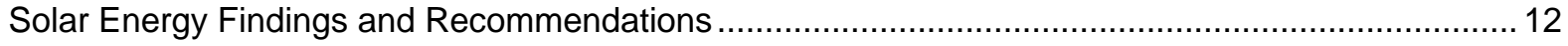

Ground Source Heat Pump Findings and Recommendations ................................................... 13

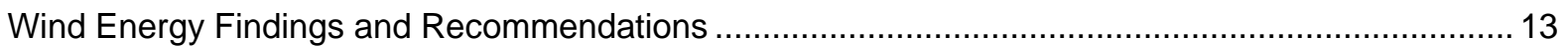

Business Case Analysis ApproachAppendix A: Business Case Analysis Approach............................. 14

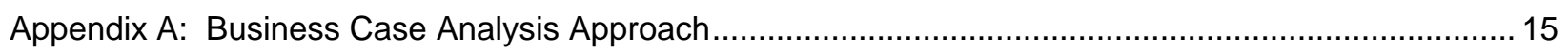

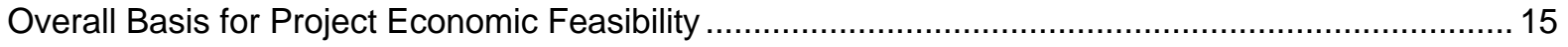

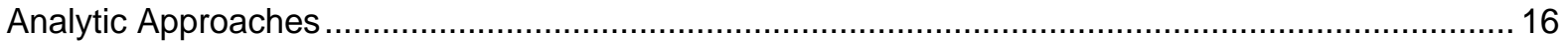

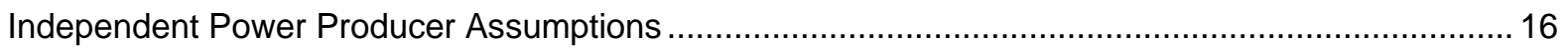

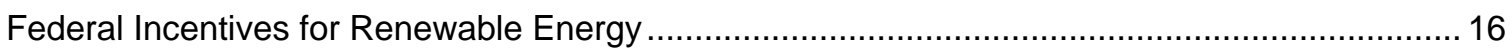

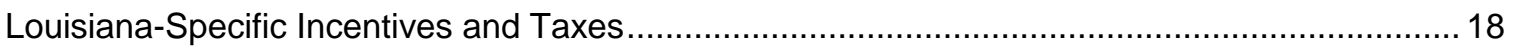

Other Independent Power Producer Assumptions …......................................................... 18

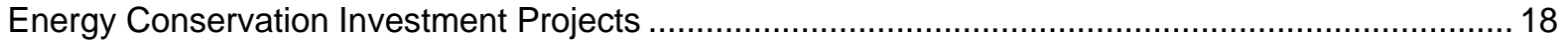

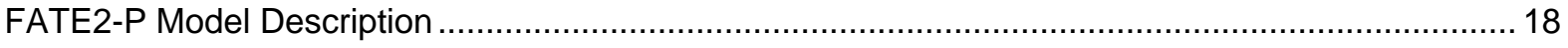

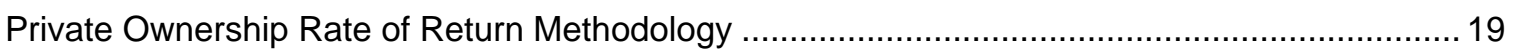


ECIP Module

The Facility Energy Decision System (FEDS) Model ............................................................... 21

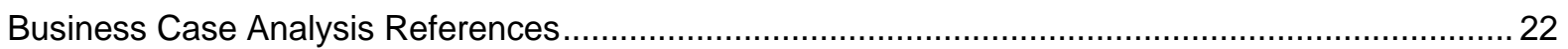

Appendix B: Analysis of Biomass and Waste-to-Energy Opportunities............................................ 25

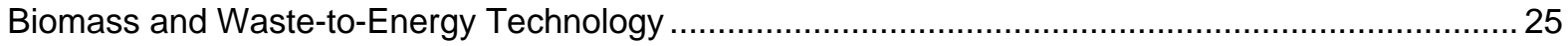

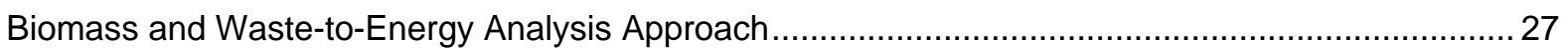

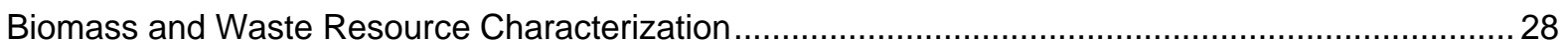

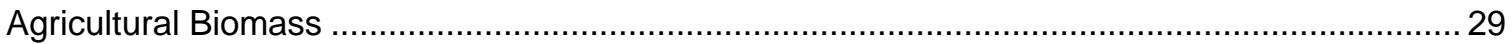

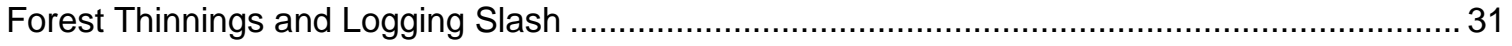

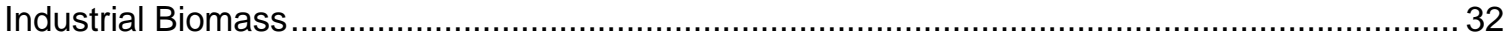

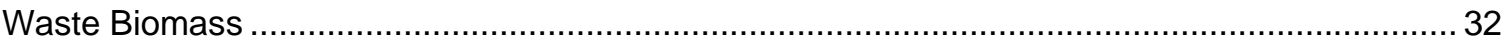

Biomass and Waste-to-Energy: Economic and Other Analysis Parameters .................................... 34

Findings: Biomass and Waste-to-Energy Opportunities.................................................................. 35

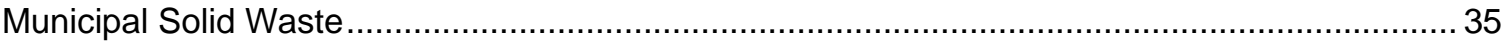

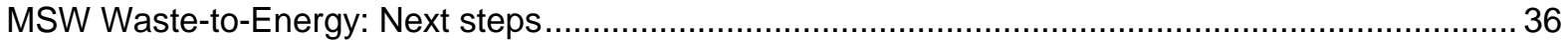

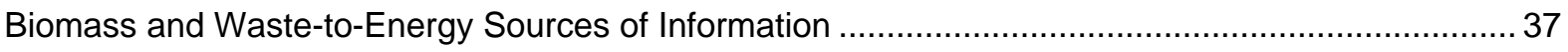

Appendix C: Analysis of Geothermal Power Plant Opportunities ....................................................... 40

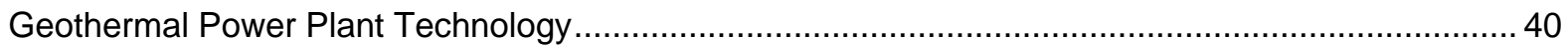

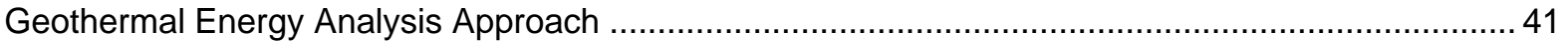

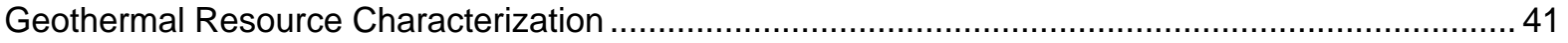

Geothermal Power Plants: Economic and Other Analysis Parameters …..................................... 43

Findings: Geothermal Power Plant Opportunities ................................................................ 43

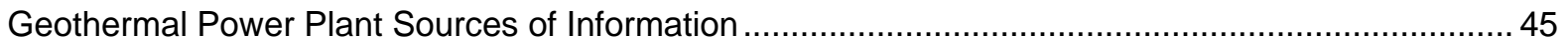

Appendix D: Analysis of Ground Source Heat Pump Opportunities ................................................ 48

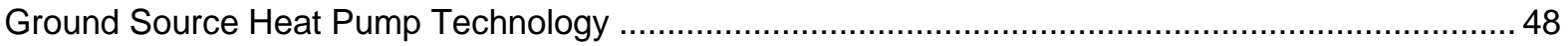

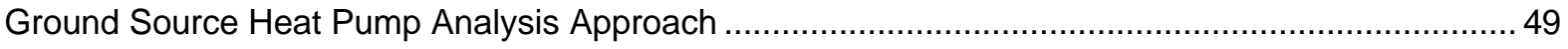

Ground Source Heat Pump Resource Characterization ................................................................ 51

Ground Source Heat Pumps: Economic and Other Analysis Parameters ........................................ 52

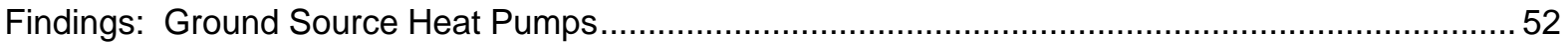

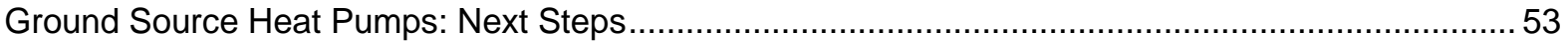

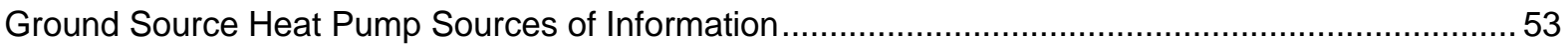

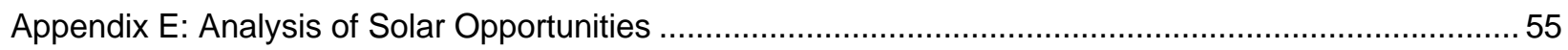

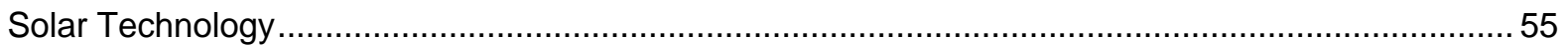

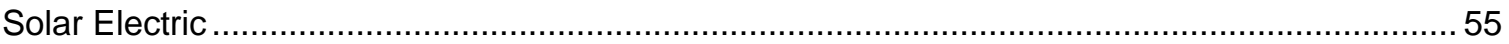

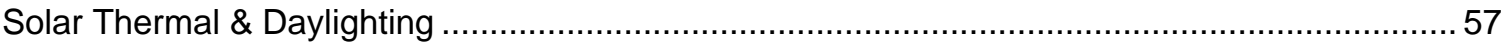

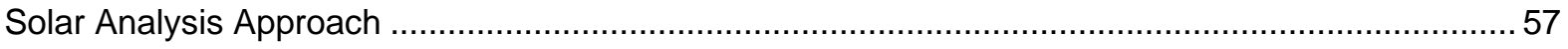

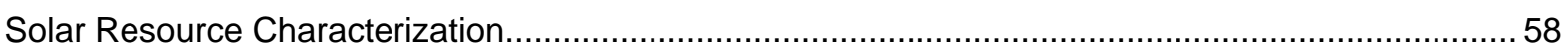




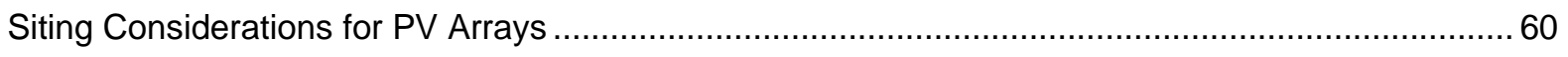

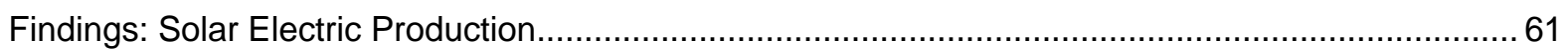

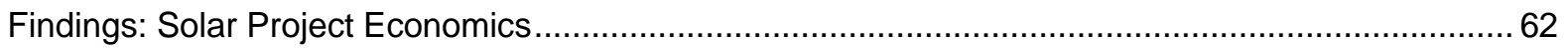

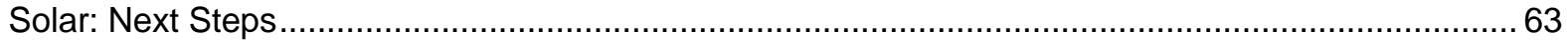

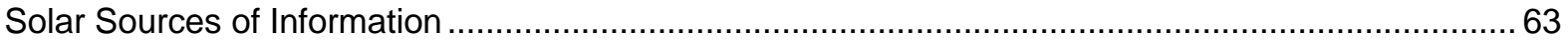

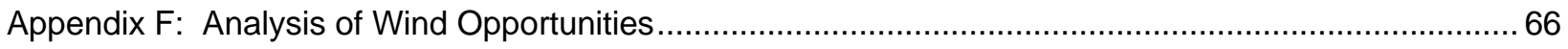

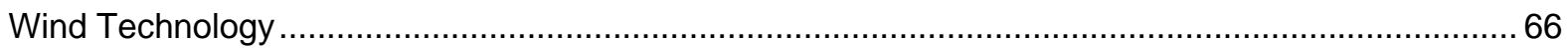

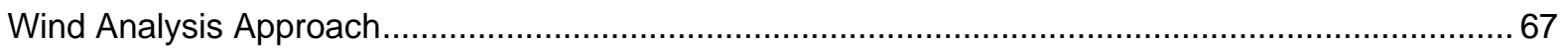

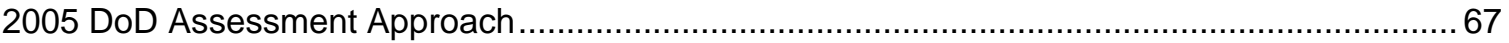

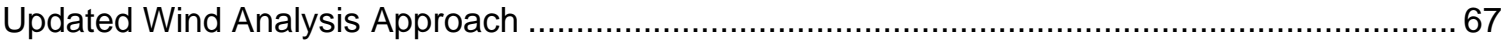

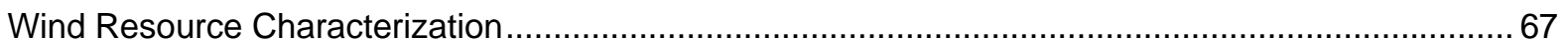

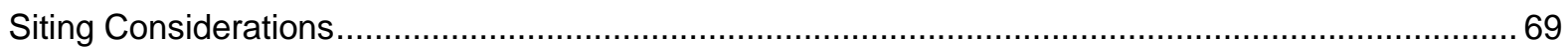

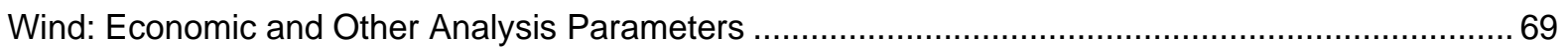

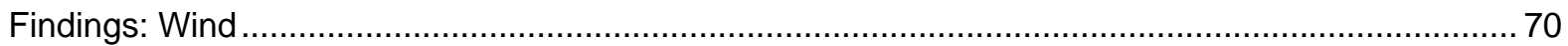

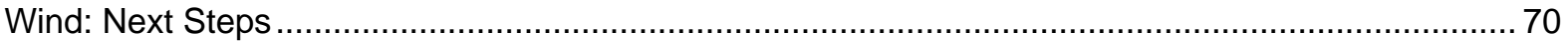

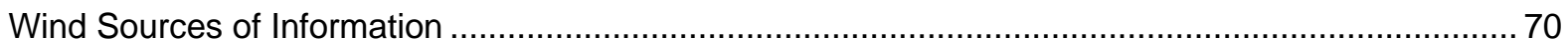

\section{Figures}

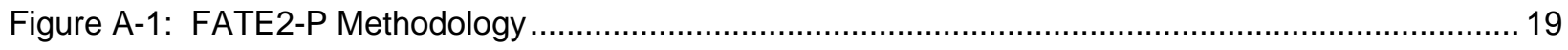

Figure C-1: Estimated temperature at 4 km depth for Eastern United States ..................................... 42

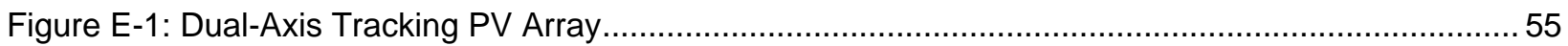

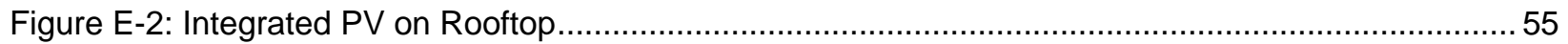

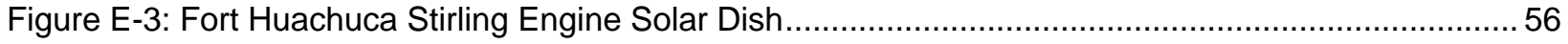

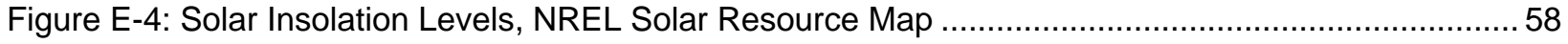

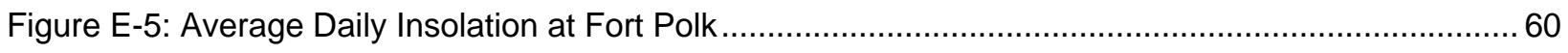

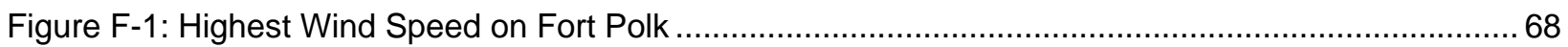




\section{Tables}

Table 1: Summary of Promising Renewable Energy Projects at Fort Polk ...........................................iv

Table 2: Legislated Renewable Energy Targets for DoD ...................................................................... 2

Table 3: Summary of Fort Polk Renewable Energy Opportunities ..................................................... 9

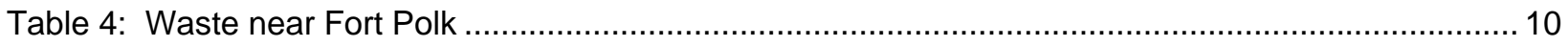

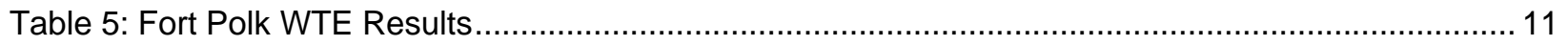

Table 6: Geothermal Performance, Cost, and Economic Characteristics .............................................. 11

Table 7: Economic Results for Solar Technologies at Fort Polk............................................................. 12

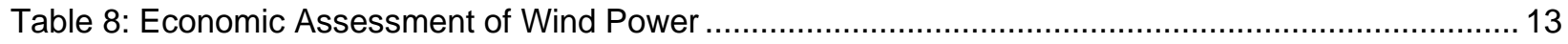

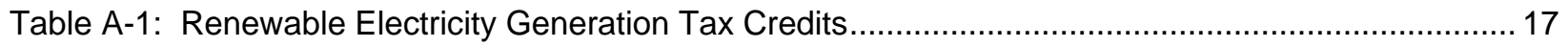

Table A-2: MACRS Depreciation Rates for Renewable Energy Projects .......................................... 17

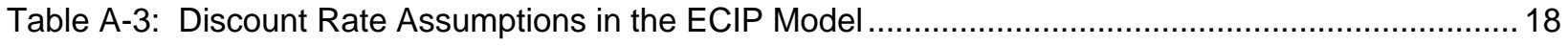

Table B-1: Crops and Biomass Production near Fort Polk ............................................................ 29

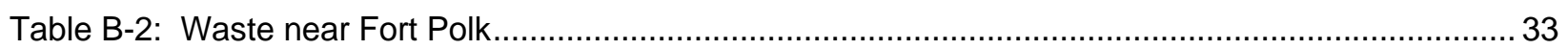

Table B-3: Economic Assumptions, constant \$2009 .................................................................... 35

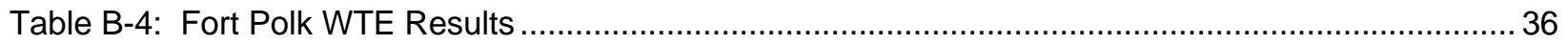

Table C-1: Geothermal Performance, Cost, and Economic Characteristics ..........................................43

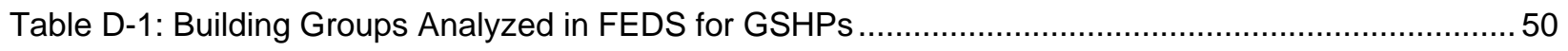

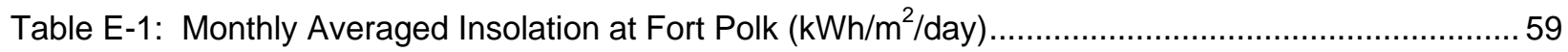

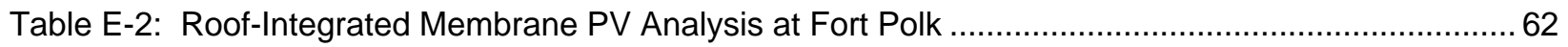

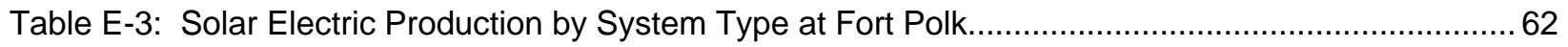

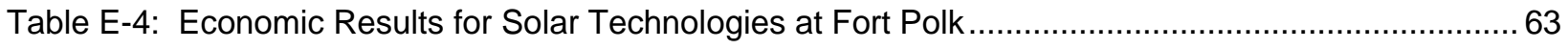

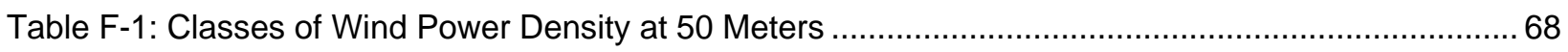

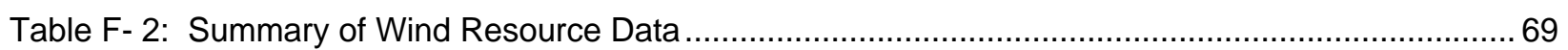

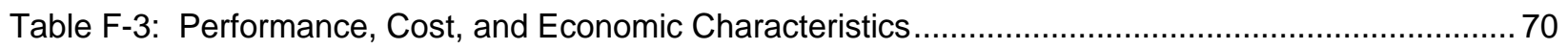

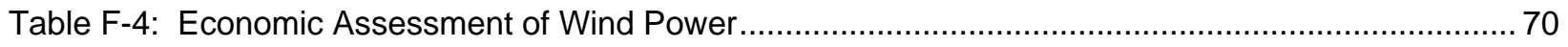




\section{Introduction}

Pacific Northwest National Laboratory (PNNL) has been directed by the U.S. Army Installation Management Command (IMCOM) to conduct detailed analyses of the potential for electricity generation at selected U.S. Army installations. The goal of the analyses is to identify economically feasible opportunities for generating electricity from renewable resourcesgeneration that is significant enough to warrant connection to the grid and/or to contribute in a meaningful way to the aggressive renewable energy goals of the Army and the Department of Defense (DoD).

In 2005, PNNL led a study to identify utility-scale electricity generation opportunities at DoD installations. That study focused on solar, wind, and geothermal. A limited number of attractive large-scale commercial opportunities were identified, and their implementation is now being pursued. The study also identified a number of potential smaller opportunities that needed to be investigated further before decisions could be made to implement projects.

This analysis of opportunities at Fort Polk is one of the suite of analyses being conducted at Army installations as follow-on to the 2005 study. The goal is to revisit potential renewable opportunities, updating the analysis for changes in economics, incentives, knowledge about the available renewable resource, and other factors. It is focused on any size project greater than $1 \mathrm{MW}$. In addition, IMCOM has directed PNNL to evaluate the potential for biomass, waste-toenergy, and retrofitting heating and cooling systems in existing buildings with ground source heat pumps (GSHPs). Retrofitting with GSHPs is obviously not an electricity generation opportunity, but it is an opportunity for significant energy savings and replacement of fossil fuels across DoD, and can contribute toward some renewable goals. As part of the analysis, IMCOM has directed PNNL to lay out the steps necessary to implement the project opportunities that are identified.

The overall findings of this analysis are summarized in the main body of the report. The business case approach that underlies the analysis of each renewable technology is documented in Appendix A. Appendix B describes the analysis conducted on biomass and waste-to-energy technologies. Appendix C describes the geothermal analysis; Appendix D, the ground source heat pump (GSHP) analysis; Appendix E, the solar analysis; and Appendix F, the wind energy analysis. 


\section{Overview of Federal and DoD Renewable Requirements}

The Army needs to satisfy multiple goals and constraints while securing its energy suppliesfocusing on procurement of the lowest-cost energy that meets high reliability standards and minimum vulnerability to interruption from natural or intentional causes. Overlaid on this challenge is the need to comply with a series of somewhat contradictory statutes and policies, as laid out in Table 2. These include:

Energy Policy Act (EPAct) Section 203. This law mandates the minimum contribution of renewable electricity to an installation's total electricity consumption. The target fractions are 3\% for FY 2007 through FY 2009, 5\% through FY 2012, and not less than $7.5 \%$ beginning in FY 2013.

Executive Order (EO) 13423. The Executive Order reiterates the EPAct goals; however, it uses a different basis than EPAct for measuring and crediting progress. For example, renewable thermal energy counts toward the renewable goal.

National Defense Authorization Act (NDAA). The NDAA codifies DoD's voluntary goal of $25 \%$ by 2025 , but does not include any interim targets. Renewable thermal energy counts toward the renewable goal.

Energy Independence and Security Act (EISA). EISA established two additional renewable goals for new buildings and retrofits. One requires $30 \%$ of domestic hot water to be supplied from solar energy, and the other requires all fossil fuels used in buildings to be displaced by 2030. This is not a power generation goal like the others, but is important to note.

Table 2: Legislated Renewable Energy Targets for DoD

\begin{tabular}{|l|c|c|c|c||}
\hline & $\begin{array}{c}\text { EPAct Section } \\
\mathbf{2 0 3}\end{array}$ & $\begin{array}{c}\text { Executive Order } \\
\mathbf{1 3 4 2 3}\end{array}$ & $\begin{array}{c}\text { National Defense } \\
\text { Authorization } \\
\text { Act }\end{array}$ & $\begin{array}{c}\text { Energy } \\
\text { Independence } \\
\text { and Security Act }\end{array}$ \\
\hline Target / Goal & $\begin{array}{c}\text { Increasing targets } \\
\text { reaching 7.5\% of } \\
\text { electric energy } \\
\text { from renewables }\end{array}$ & $\begin{array}{c}7.5 \% \text { of electric energy } \\
\text { from renewables; 50\% } \\
\text { from new (post-1998) } \\
\text { sources }\end{array}$ & $\begin{array}{c}\text { Equivalent of 25\% } \\
\text { of electric energy } \\
\text { from renewables }\end{array}$ & $\begin{array}{c}30 \% \text { of hot water } \\
\text { demand from solar }\end{array}$ \\
\hline Target Dates & 2013 & 2013 & 2025 & $\begin{array}{c}\text { All new } \\
\text { construction / } \\
\text { major renovations }\end{array}$ \\
\hline Mandatory? & Yes & Yes & No & Yes \\
\hline $\begin{array}{l}\text { Considers thermal } \\
\text { energy "renewable"? }\end{array}$ & No & Yes & Yes & N/A \\
\hline \hline
\end{tabular}

This assessment is primarily for renewable energy provision and retrofit applications in existing buildings. Accordingly, potential in new building construction is mentioned only in passing. The U.S. Department of Energy (DOE) is responsible for developing guidance for EPAct and EO 13423. DOE's guidelines for EO compliance, unlike EPAct, allow credit for renewable energy that reduces electricity use from thermal sources; however, it adds a requirement that at 
least $50 \%$ of renewable energy must come from "new" resources: those put into service after January 1, 1999.

Congress did not provide a definition of "renewable" in the NDAA language, and DOE is not responsible for establishing DoD or Army policies to achieve the goals in the NDAA. The current Army energy strategy and associated draft renewable policy takes an expansive view of renewables that encompasses thermal energy from renewable sources. As a result, the Army needs to proceed in a way that makes sense for the Army in a good faith effort to satisfy Congressional, Administration, and Pentagon mandates and directives. The expectation is that the Army will meet the stricter definitions of EPAct on its way to meeting the much higher renewable goals of the NDAA. 


\section{Analysis of Renewables at Fort Polk}

PNNL's renewable energy analysis includes a preliminary assessment based on readily available resources, a site visit to present the preliminary findings and gather additional information, and a concluding assessment, which is documented in this report.

The site visit to Fort Polk took place on February 16, 2010, with Amy Solana and Brian Boyd attending for PNNL. Fort Polk personnel at the briefing included Ellis Smith (Director of Public Works), Devan O'Dell (Engineering Intern), John Joiner (Lead Engineer), Jim Murgas (contracted Global Information System [GIS] Manager), Brett Pennington (Department of Public Works [DPW]), Frederick Toni Polk (DPW), and Jason Spell (DPW). Separate discussions were held with Dr. Charles Stagg (Environmental Director), Bruce Martin (Post Forester), Steve Gibson (Solid Waste Management), and Tim Fitzgerald (Solid Waste Management) during the site visit.

\section{Approach for Identifying, Analyzing, and Implementing Renewable Energy Projects}

Renewable energy resources are unlike conventional resources because the "fuel" is essentially free. However, harnessing this free resource requires substantial investment in resource exploration, characterization, and collection; project development; and ongoing maintenance and operation. A renewable resource is like purchasing a new car with a lifetime of fuel as part of the purchase agreement. First costs are much higher, but total cost may be (should be) lower over the long run.

Economic development of renewable energy depends upon:

- Access to a renewable resource,

- Development costs, and

- Financing that is economically attractive and allowed by federal and DoD regulations.

Each of these is critically important.

Obviously, a renewable resource has to be available and accessible to be developed. The best resources are those with the greatest potential for displacing conventional fuels or power supplies. Development cost, however, is the great equalizer, and a project based upon an excellent resource that is located many miles away may be inferior to a project based upon a lesser resource nearby. For example, an excellent wind resource far from an adequate transmission line may be less attractive than an inferior resource adjacent to a transmission line. Similarly, waste resources that could be used in a central plant may not be economic, even if they are "free," if the transportation, handling, and storage costs are greater than the cost of continued use of conventional heating fuels.

Development costs are relatively comparable for similar size projects, irrespective of resource quality. This is why the quality of the resource is so important-namely, for the same investment, you obtain more from a high-quality resource than a low-quality one. But, development costs also include access to transmission capacity for shipping power to users, or 
alternatively, access to a retail customer. This is a critical difference because power shipped over transmission lines has to compete against the prevailing wholesale price for power from conventional resources. Typically, renewables are not competitive in these markets, unless a buyer specifically demands renewable power. On the other hand, if the power can be used onsite to displace power purchased from the local utility, it competes against that customer's retail power price or utility rate. Because retail power prices include costs for transmission, distribution, and administrative costs, they are higher than wholesale power prices and make competing renewable projects more attractive economically.

It is important that economic analyses of renewable energy opportunities use realistic data on avoided energy costs, project costs, and available incentive funds, if any. A common analytic mistake is the use of average cost per $\mathrm{kWh}$ - the so-called "blended" rate. Using the blended rate will lead to inaccurate results when the renewable resource is intermittent (like wind and solar) because intermittent resources cannot be guaranteed to reduce peak demand. Even nonintermittent resources may not result in reduced peak demand because of periodic maintenance shutdowns and unscheduled outages. The economic analyses in this report use only the energy component of the power bill to evaluate intermittent resources, which is admittedly conservative. The blended rate is used for economic analysis of base-load resources.

Additionally, the installation's utility may impose a standby or other fee in the face of a major onsite generation project that needs to be reflected in the project's cost calculation. The analyses conducted here make no assumptions regarding standby charges because those are typically assessed on a project-by-project basis.

The economic analyses in this report used two perspectives: Energy Conservation Investment Program (ECIP) funding and third-party financing. Under the latter arrangement, power is sold from large generation projects through a contract that is commonly called a power purchase agreement (PPA). This analysis assumes that an internal rate of return (IRR) of $10 \%$ is the minimum required to attract a developer. GSHPs can be third-party financed through Utility Energy Services Contracts (UESCs) or Energy Savings Performance Contracts (ESPCs). These are implemented by a third party but result in government ownership. The ECIP analyses assume that projects are not cost-effective if the savings-to-investment ratio (SIR) is less than 1.0. These two options are the lowest-cost among all the options typically available to Army customers.

\section{Importance of Financing Mechanisms for Project Feasibility}

Financing is a critical determinant of development costs because the high first costs are sensitive to financial factors such as incentive payments, tax breaks, and interest rates. Incentive payments and tax breaks reduce first costs, lowering both the overall project cost and interest costs. Because financing is so critical, project economics (payback rates, life-cycle costs, etc.) constitute the best initial screen for project potential. That screen needs to reflect various financing alternatives, which in turn, helps energy managers decide on the best project development approach.

This study focuses on "utility-scale" projects on the premise that if a good renewable resource exists at a site, it should be developed to its maximum potential. Projects smaller than $1 \mathrm{MW}$ are 
not analyzed because of their small contribution to renewable goals and their poor economics compared to larger projects. These large projects typically exceed any realistic expectation for appropriated funding, and so the assessments focus on commercial (third-party) development of projects. Besides funding limitations, there are other reasons that these large projects should be implemented by third-party investors - under current DoD philosophy, resource development is not a core DoD mission and should be left to the private sector. In addition, private developers can take advantage of tax credits, and they value renewable energy credits (RECs) more highly than the Army does. As a result, letting the developers claim tax credits and retain RECs, if available, will reduce the cost of energy to the installation if the developer is selling power from the project to the site.

\section{The Political and Economic Environment for Renewables at Fort Polk}

\section{Fort Polk Energy Characterization}

Fort Polk is provided electricity by Entergy Louisiana through two separate billing meters. The site consumed a combined total of 193,112 MWh in FY 2009; the north meter supplied 32,838 MWh and the south meter supplied 160,273 MWh. Demand in FY 2009 was 5.7 $\mathrm{MW}_{\text {average }}$ and 7.1 $\mathrm{MW}_{\text {peak }}$ (in October) on the north meter, and $24.2 \mathrm{MW}_{\text {average }}$ and 31.4 $\mathrm{MW}_{\text {peak }}$ in July for the south meter. The combined total electricity bill in FY 2009 was $\$ 12.8$ million.

Entergy Louisiana charges both the North Fort and South Fort for electricity through the same block structured schedule. FY 2009 electric costs averaged about $6.87 \phi / \mathrm{kWh}$ for the north meter and $6.74 \phi / \mathrm{kWh}$ for the south meter. Because of the block structure billing rate, the blended and kWh-only rates are identical. For this assessment, the higher rate associated with the north meter is used for the intermittent resources, wind and solar. The higher rate was selected because the consumption on the North Fort is sufficient to justify a wind or solar project, but it is not large enough to justify the base-load generation from biomass, waste-to-energy, or geothermal resources. Alternately, the lower rate associated with the South Fort was applied to the biomass, waste-to-energy, and geothermal resources because of the larger energy demand. The GSHP analysis used both because buildings across the Fort could benefit from efficient heating and cooling equipment.

\section{State Incentives for Renewable Project Development}

State incentives for renewable energy in Louisiana include a corporate tax credit and net metering. The tax credit is $50 \%$ of the installed cost up to $\$ 25,000$, or $\$ 12,500$ per system, and applies to photovoltaics (PV), wind, and solar thermal. The credit is insignificant in comparison to the costs of the systems evaluated; consequently, they were not included in our analysis. Louisiana's net metering law allows commercial customer generators to net meter up to $300 \mathrm{~kW}$ (DSIRE 2010), which is also relatively small compared to the project sizes being evaluated here.

\section{Federal Incentives for Renewable Project Development}

Federal incentives for renewable energy include investment tax credits for corporations, significantly accelerated depreciation of equipment, and production tax credits. A $30 \%$ tax credit is available for PV projects, and 10\% is available for geothermal and biomass electricity projects, with no incentive limits. The credits may be taken on equipment placed in service before 
January 1, 2017. Wind is not eligible for the business energy tax credit. The tax basis for depreciation must be reduced by the amount of any federal subsidy used in the financing of the eligible equipment.

Depreciation for most renewable energy equipment qualifies for significantly accelerated depreciation. For solar, wind, and geothermal, the modified accelerated cost recovery system (MACRS) provides for 5-year recovery of the cost of equipment. The 5-year recovery period does not apply to biomass or waste-to-energy (WTE) equipment.

The renewable energy production tax credit (PTC), originally established in 1992, provides a tax credit for each kilowatt-hour of electricity produced. The PTC is $2.1 \phi / \mathrm{kWh}$ for wind, geothermal, and closed-loop biomass (biomass that is grown with the sole purpose of being used to generate energy), and can be taken for 10 years. The PTC is $1.1 \phi / \mathrm{kWh}$ for electricity produced from open-loop biomass and municipal solid waste resources and can be taken for 5 years. Solar electricity generation has been excluded for equipment placed in service after December 2005. The PTC has been allowed to lapse and has then been renewed several times.

Available tax incentives reduce the first-year costs of qualified renewable projects. The lower first cost also reduces the amount of money that must be borrowed to develop a project and thus, the associated interest and carrying costs. The combination reduces the delivered cost of power if developed by a private party with a tax obligation. Government-owned projects do not benefit from tax-based incentives. All of the PPA analyses conducted in this report assume that the PTC and other tax credits will be available when the equipment is placed in service. 


\section{Results and Recommendations}

A summary of analysis results is presented in Table 3, broken down into economic (green), marginal (yellow), or uneconomic (red) projects. The underlying analyses and recommendations for each of these technologies and potential projects are provided in the following subsections. 
Table 3: Summary of Fort Polk Renewable Energy Opportunities

\begin{tabular}{|c|c|c|c|c|c|c|c|c|}
\hline & $\begin{array}{l}\text { Renewable } \\
\text { Resource and } \\
\text { Technology } \\
\end{array}$ & $\begin{array}{l}\text { Resource } \\
\text { Estimate }\end{array}$ & $\begin{array}{l}\text { Earliest } \\
\text { Output }\end{array}$ & Figures of Merit & $\begin{array}{l}\text { Financing } \\
\text { Mechanisms } \\
\text { Evaluated }\end{array}$ & $\begin{array}{l}\text { Location-- } \\
\text { Requirements }\end{array}$ & Key Assumptions & $\begin{array}{l}\text { Next Steps } \\
\text { Comments }\end{array}$ \\
\hline 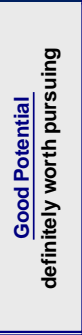 & $\begin{array}{l}\text { Municipal Waste- } \\
\text { to-Energy Plant } \\
\text { using Combustion } \\
\text { or Gasification } \\
\text { Technologies }\end{array}$ & $\begin{array}{c}10 \text { - } 41 \mathrm{MW} \\
\text { (using Polk, } \\
\text { Timberlane, } \\
\text { Sabine Parish, } \\
\text { or Jefferson } \\
\text { Davis Parish LF } \\
\text { MSW) }\end{array}$ & 2012 & $\begin{array}{c}\text { ECIP scenario: 0.9- } \\
1.5 \text { SIR, } 9.6-15.8 \\
\text { year payback at } \\
6.74 \$ / k W h \\
\\
\text { IPP scenario: } 6.7- \\
12.7 \% \text { IRR at } \\
6.74 \llbracket / k W h \\
\\
\text { (function of } \\
\text { technology and } \\
\text { plant size) } \\
\end{array}$ & $\begin{array}{l}\text { ECIP } \\
\text { IPP }\end{array}$ & $\begin{array}{c}\text { A5-acre site near } \\
\text { major roads, a utility } \\
\text { substation, water, } \\
\text { sewage, and an } \\
\text { appropriate industrial } \\
\text { infrastructure, plus } \\
\text { feedstock storage } \\
\text { space. }\end{array}$ & $\begin{array}{c}\text { MSW available for WTE } \\
\text { plant, and can be brought } \\
\text { on site. } \\
\text { Plant location can be } \\
\text { secured on Fort Polk. } \\
\text { Tipping fees of } \$ 20- \\
\text { 30/ton available with } \\
\text { MSW delivery to plant. }\end{array}$ & $\begin{array}{l}\text { Confirm waste } \\
\text { availability and tipping } \\
\text { fees. Economics are } \\
\text { highly dependent upon } \\
\text { tipping fee available } \\
\text { from waste providers. }\end{array}$ \\
\hline 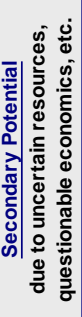 & $\begin{array}{l}\text { Geopressured- } \\
\text { Geothermal } \\
\text { Generation Plant }\end{array}$ & Unknown & Unknown & Unknown & $\begin{array}{l}\text { None (out of } \\
\text { assessment } \\
\text { scope) }\end{array}$ & $\begin{array}{c}\text { Near oil or gas wells, } \\
\text { and a utility } \\
\text { substation. }\end{array}$ & $\begin{array}{l}\text { Funding for exploration } \\
\text { available through DOE } \\
\text { and/or DoD. There is } \\
\text { significant developer } \\
\text { interest for development } \\
\text { on or near Fort Polk. }\end{array}$ & $\begin{array}{l}\text { There is likely potential } \\
\text { for energy generation, } \\
\text { but the resource must } \\
\text { be explored. } \\
\text { Consider } \\
\text { environmental impacts. } \\
\text { Confirm availability of } \\
\text { proposed DOE and } \\
\text { DoD funding. }\end{array}$ \\
\hline \multirow{5}{*}{ 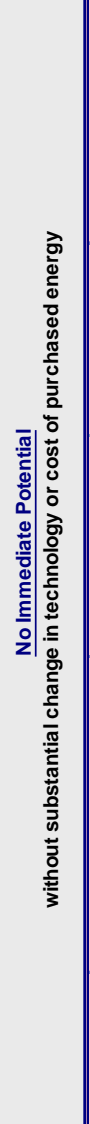 } & $\begin{array}{c}\text { Cellulosic } \\
\text { Biomass Energy } \\
\text { Plant }\end{array}$ & $57 \mathrm{MW}$ & 2013 & $\begin{array}{l}7.69 \$ / \mathrm{kWh} \\
\text { projected electric } \\
\text { generation rate }\end{array}$ & IPP & $\begin{array}{c}\text { A5-acre site near } \\
\text { major roads, a utility } \\
\text { substation, water, } \\
\text { sewage, and an } \\
\text { appropriate industrial } \\
\text { infrastructure, plus } \\
\text { feedstock storage } \\
\text { space. }\end{array}$ & $\begin{array}{l}\text { Regional wood waste is } \\
\text { unavailable at present. }\end{array}$ & $\begin{array}{l}\text { If feedstock resources } \\
\text { become available, } \\
\text { explore cogeneration } \\
\text { plant feasibility. }\end{array}$ \\
\hline & $\begin{array}{l}\text { High Temperature } \\
\text { Geothermal } \\
\text { Generation Plant }\end{array}$ & $5 \mathrm{MW}$ & 2012 & $\begin{array}{c}\text { ECIP scenario: } 0.4 \\
\text { SIR, 32.8-year } \\
\text { payback at } \\
6.74 \$ / \mathrm{kWh} \\
\\
\text { IPP scenario: } 10 \% \\
\text { IRR at } 17.6 \$ / \mathrm{kWh}\end{array}$ & $\begin{array}{l}\text { ECIP } \\
\text { IPP }\end{array}$ & $\begin{array}{c}\text { Near transmission } \\
\text { lines. }\end{array}$ & $\begin{array}{l}\text { Only geothermal power } \\
\text { will be generated from } \\
\text { new wells; gas and oil } \\
\text { will not be harvested. }\end{array}$ & $\begin{array}{l}\text { Nothing unless } \\
\text { available geothermal } \\
\text { resource is discovered. }\end{array}$ \\
\hline & $\begin{array}{l}\text { Utility Grade Wind } \\
\text { Farm }\end{array}$ & $\begin{array}{c}1.5 \mathrm{MW} \\
\text { installed } \\
\text { capacity at } 7.4 \% \\
\text { capacity factor }\end{array}$ & NA & $\begin{array}{c}\text { ECIP scenario: } \\
\text { negative SIR, 155- } \\
\text { year payback at } \\
6.87 \$ / \mathrm{kWh} \\
\text { IPP scenario: } 10 \% \\
\text { IRR at } 57 \$ / \mathrm{kWh}\end{array}$ & $\begin{array}{l}\text { ECIP } \\
\text { IPP }\end{array}$ & $\begin{array}{l}\text { Within } 1 \text { mile of } \\
\text { transmission line. } \\
\text { Avoid airport } \\
\text { interference. }\end{array}$ & $\begin{array}{l}\text { Project would be located } \\
\text { far enough away from the } \\
\text { on-site airport and close } \\
\text { enough to transmission } \\
\text { for interconnection. }\end{array}$ & $\begin{array}{l}\text { Consider small-scale } \\
\text { demonstration turbine. } \\
\text { If incentives become } \\
\text { available or there is a } \\
\text { rate increase, the } \\
\text { viability of a large-scale } \\
\text { wind project should be } \\
\text { reevaluated. }\end{array}$ \\
\hline & $\begin{array}{c}\text { Utility-Grade Solar } \\
\text { Electric Power } \\
\text { Plant }\end{array}$ & $\begin{array}{c}1.0 \mathrm{MW} \text { of roof- } \\
\text { integrated PV } \\
\text { generating } 575 \\
\text { MWh annually, } \\
\text { potentially more } \\
\text { generation from } \\
\text { ground- } \\
\text { mounted PV }\end{array}$ & NA & $\begin{array}{l}\text { ECIP scenario: } 0.4 \\
\text { SIR, } 40-50 \text { year } \\
\text { payback at } \\
6.87 \$ / \mathrm{kWh} \\
\\
\text { IPP scenario: } 10 \% \\
\text { IRR at } 28.7- \\
36.9 \$ / \mathrm{kWh} \\
\text { (depending on } \\
\text { technology) }\end{array}$ & $\begin{array}{l}\text { ECIP } \\
\text { IPP }\end{array}$ & $\begin{array}{l}\text { Rooftops, especially } \\
\text { where replacing } \\
\text { roofs. Also open } \\
\text { ground area near } \\
\text { high-voltage power } \\
\text { lines, away from } \\
\text { obstruction by } \\
\text { shadows or danger of } \\
\text { vandalism. }\end{array}$ & $\begin{array}{l}\text { Capital cost are too high } \\
\text { for economic project. }\end{array}$ & $\begin{array}{c}\text { If large incentives } \\
\text { become available or } \\
\text { there is a rate increase, } \\
\text { the feasibility of a solar } \\
\text { project should be } \\
\text { reevaluated. }\end{array}$ \\
\hline & $\begin{array}{c}\text { Ground Source } \\
\text { Heat Pump } \\
\text { (Thermal Energy) }\end{array}$ & NA & NA & NA & NA & $\begin{array}{l}\text { Space near building } \\
\text { for heat exchange } \\
\text { wells or loop. }\end{array}$ & $\begin{array}{l}\text { Heating load and fossil } \\
\text { fuel costs are too low for } \\
\text { economic retrofits. }\end{array}$ & $\begin{array}{l}\text { New construction } \\
\text { should be considered. } \\
\text { No immediate next } \\
\text { steps are } \\
\text { recommended. }\end{array}$ \\
\hline
\end{tabular}

WTE $=$ Waste-to-energy

$\mathrm{CSP}=$ Concentrating solar power 


\section{Waste-to-Energy Findings and Recommendations}

MSW was found to be the most economic option for generating a significant amount of renewable electricity at Fort Polk. Waste disposed of within 60 miles of Fort Polk totals 556,243 tons per year and is expected to remain constant in the future. The regional landfills are summarized, with their respective tipping fees, in Table 4.

Table 4: Waste near Fort Polk

\begin{tabular}{|c|c|c|c|c|c|c|}
\hline Site & $\begin{array}{l}\text { Collection } \\
\text { Location }\end{array}$ & $\begin{array}{c}\text { Miles } \\
\text { from } \\
\text { Fort Polk }\end{array}$ & $\begin{array}{l}\text { Tipping } \\
\text { Fee (\$) }\end{array}$ & $\begin{array}{l}\text { Assumed } \\
\text { Cost Savings } \\
\text { (\$) }\end{array}$ & $\begin{array}{l}\text { Available MSW } \\
\text { (tons/year) }\end{array}$ & $\begin{array}{c}\text { Potential } \\
\text { Electricity } \\
\text { Generation (MW) }\end{array}$ \\
\hline Fort Polk & Fort Polk, LA & 0 & $\$ 21.00$ & $\$ 21.00$ & $8,069 *$ & 0.9 \\
\hline $\begin{array}{l}\text { Timberlane } \\
\text { Landfill }\end{array}$ & Oakdale, LA & 37 & $\$ 27.69$ & $\$ 13.84$ & 112,863 & 12.4 \\
\hline $\begin{array}{l}\text { Sabine Parish } \\
\text { Landfill }\end{array}$ & Many, LA & 39 & $\$ 27.69$ & $\$ 13.84$ & 81,715 & 9.0 \\
\hline $\begin{array}{l}\text { Jefferson Davis } \\
\text { Parish Landfill }\end{array}$ & Welsh, LA & 58 & $\$ 20.10$ & $\$ 10.05$ & 361,665 & 39.6 \\
\hline & & & & TOTAL & 564,312 & 61.9 \\
\hline
\end{tabular}

* This value combines the site cantonment generation of 6,959 tons/year and the conservative assumption of 1,110 tons/year generated at the Solid Waste Sorting Facility.

Fort Polk's waste, combined with waste from Timberlane Landfill, Sabine Parish Landfill, and Jefferson Davis Parish Landfill, was evaluated for economic feasibility as feedstock for either a combustion or a gasification WTE project. Project economics will depend on the availability and price of waste as well as the actual plant size, capital costs, and operating costs. The most cost-effective analyzed scenarios are presented in Table 5. They have SIRs ranging from 1.1 to 1.8 and IRRs ranging from $8 \%$ to almost $15 \%$.

It is recommended to pursue a WTE project at Fort Polk. To do this, Fort Polk must determine the amount of regional MSW that is actually available for a WTE plant and verify the associated tipping fees. The economics depend greatly on capturing a portion of the tipping fee. Detailed results are provided in Appendix B. 
Table 5: Fort Polk WTE Results

\begin{tabular}{|c|c|c|c|c|c|c|}
\hline Waste Source & $\begin{array}{c}\text { Fort Polk } \\
\text { and } \\
\text { Timberlane } \\
\text { Landfill }\end{array}$ & $\begin{array}{c}\text { Fort Polk and } \\
\text { Timberlane } \\
\text { Landfill }\end{array}$ & $\begin{array}{c}\text { Fort Polk } \\
\text { and Sabine } \\
\text { Parish } \\
\text { Landfill }\end{array}$ & $\begin{array}{c}\text { Fort Polk } \\
\text { and Sabine } \\
\text { Parish } \\
\text { Landfill }\end{array}$ & $\begin{array}{c}\text { Fort Polk } \\
\text { and } \\
\text { Jefferson } \\
\text { Davis } \\
\text { Parish } \\
\text { Landfill } \\
\end{array}$ & 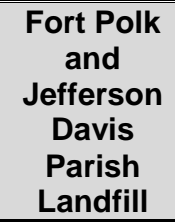 \\
\hline Technology & Combustion & Gasification & Combustion & Gasification & Combustion & Gasification \\
\hline Plant Size & 13.3 MW & 17.6 MW & $9.9 \mathrm{MW}$ & $13.1 \mathrm{MW}$ & $40.7 \mathrm{MW}$ & $53.8 \mathrm{MW}$ \\
\hline Feedstock Amount & $\begin{array}{c}120,932 \\
\text { tons/yr }\end{array}$ & $\begin{array}{c}120,932 \\
\text { tons/yr }\end{array}$ & 89,784 tons/yr & $\begin{array}{l}89,784 \\
\text { tons/yr }\end{array}$ & $\begin{array}{c}369,734 \\
\text { tons/yr }\end{array}$ & $\begin{array}{c}369,734 \\
\text { tons/yr }\end{array}$ \\
\hline Total Plant Cost & $\$ 3,455 / \mathrm{kW}$ & $\$ 4,092 / \mathrm{kW}$ & $\$ 3,667 / \mathrm{kW}$ & $\$ 4,343 / \mathrm{kW}$ & $\$ 2,763 / \mathrm{kW}$ & $\$ 3,272 / \mathrm{kW}$ \\
\hline Capital Cost & $\$ 3,322 / \mathrm{kW}$ & $\$ 3,934 / \mathrm{kW}$ & $\$ 3,526 / \mathrm{kW}$ & $\$ 4,176 / \mathrm{kW}$ & $\$ 2,656 / \mathrm{kW}$ & $\$ 3,146 / \mathrm{kW}$ \\
\hline Sales Tax & $\$ 132 / \mathrm{kW}$ & $\$ 157 / \mathrm{kW}$ & $\$ 141 / \mathrm{kW}$ & $\$ 167 / \mathrm{kW}$ & $\$ 106 / \mathrm{kW}$ & $\$ 126 / k W$ \\
\hline Fixed O\&M* Cost & $\$ 108 / \mathrm{kW}$ & $\$ 122 / \mathrm{kW}$ & $\$ 119 / \mathrm{kW}$ & $\$ 152 / k W$ & $\$ 86 / \mathrm{kW}$ & $\$ 57 / \mathrm{kW}$ \\
\hline Variable O\&M Cost & $-0.5 \$ / k W h$ & $-0.7 \$ / k W h$ & $-0.5 \Phi / \mathrm{kWh}$ & $-0.7 \Phi / k W h$ & $-0.0 \$ / \mathrm{kWh}$ & $-0.3 \$ / k W h$ \\
\hline Feedstock Cost & $-\$ 14.32 /$ ton & $-\$ 14.32 /$ ton & $-\$ 14.48 /$ ton & $-\$ 14.48 /$ ton & $-\$ 10.29 /$ ton & $-\$ 10.29 /$ ton \\
\hline SIR & 1.5 & 1.3 & 1.4 & 1.1 & 1.8 & 1.8 \\
\hline Simple Payback & 9.3 years & 11.1 years & 10.1 years & 12.6 years & 7.7 years & 8.1 years \\
\hline IRR, No Financing & $11.63 \%$ & $9.42 \%$ & $10.58 \%$ & $8.03 \%$ & $14.48 \%$ & $13.38 \%$ \\
\hline
\end{tabular}

*Operation and Maintenance

\section{Geothermal Power Plant Findings and Recommendations}

According to existing data, naturally occurring hot water/steam fields and elevated temperatures at economic depths (less than 3,000 m) near Fort Polk show poor potential for economic electricity generation, based on drilling new wells for the sole purpose of geothermal power production. However, DOE, DoD, and developers are interested in exploring geopressuredgeothermal resources, which allows both geothermal and fossil energy to be harvested from the same well. This results in a highly attractive and economic project.

The analysis of power generation with new wells assumed that electric transmission lines located on or near a potential geothermal development area would be available to transmit power without substantial additional investment. The economic results of this scenario are shown in Table 6. The use of geopressured-geothermal resources was not analyzed for economic potential because data are not readily available, and it is beyond the scope of this assessment.

Table 6: Geothermal Performance, Cost, and Economic Characteristics

\begin{tabular}{|c|c|c|c|c|c|c|}
\hline $\begin{array}{c}\text { Assumed } \\
\text { Temperature at } \\
\mathbf{3 0 0 0} \text { meters }\end{array}$ & $\begin{array}{c}\text { Capacity } \\
\text { Factor }\end{array}$ & $\begin{array}{c}\text { Technology } \\
\text { Type }\end{array}$ & $\begin{array}{c}\text { Project } \\
\text { Size }\end{array}$ & $\begin{array}{c}\text { Estimated } \\
\text { Annual } \\
\text { Production }\end{array}$ & $\begin{array}{c}\text { Average } \\
\text { Cost of } \\
\text { Energy }\end{array}$ & $\begin{array}{c}\text { Total Capital } \\
\text { Cost }\end{array}$ \\
\hline $212^{\circ} \mathrm{F}\left(100^{\circ} \mathrm{C}\right)$ & $96 \%$ & Binary & $5 \mathrm{MW}$ & $43,800 \mathrm{MWh}$ & $17.57 \mathrm{kWWh}$ & $\$ 11,023 / \mathrm{kW}$ \\
\hline
\end{tabular}


It is recommended that Fort Polk work with DOE and DoD to investigate the potential for geopressured-geothermal development. Geothermal power using high-temperature resources from new wells should not be further explored at this time. Detailed results are provided in Appendix C.

\section{Biomass Findings and Recommendations}

The availability of animal waste, industrial waste, landfill gas, and wastewater treatment plant (WWTP) sludge is inadequate to consider a large biomass generation project. Other potentially available biomass fuels, including crop residue, dedicated biomass crops, and logging slash do not support economic electricity generation at this time, although logging slash (wood waste) may have project potential in the future.

Using only offsite slash for a renewable biomass plant, there are sufficient resources for a 57MW plant that could produce electricity at $7.69 \phi / \mathrm{kWh}$, which is close to Fort Polk's current rate. The economics are marginal, but the likelihood of any of these resources becoming available depends on the region's wood product industries. Additionally, the generation far exceeds Fort Polk's electricity consumption; therefore, a smaller plant is more likely to be approved should feedstock resources become available. A smaller plant will be less attractive based on economies of scale and may only be feasible if cogeneration is a possibility. See Appendix B for more details.

\section{Solar Energy Findings and Recommendations}

With current electricity prices and the available solar resource, PV systems did not prove to be economic. Fort Polk's solar resource was found to be $4.95 \mathrm{kWh}_{\text {solar }} / \mathrm{m}^{2} /$ day on a south-facing, latitude-tilted surface. Ground-mounted fixed-angle PV, axis-tracking PV, and buildingintegrated roof-mounted PV were all far too expensive for the amount of energy that could be produced. Table 7 shows the detailed economic results for the ECIP funding and third-party financing analyses for these three PV technologies. Even with carbon taxes and REC sales, these projects would be difficult to justify. See Appendix E for analysis details.

Table 7: Economic Results for Solar Technologies at Fort Polk

\begin{tabular}{||l|c|c|c||}
\hline & $\begin{array}{c}\text { Ground-Mounted } \\
\text { Fixed-Tilt PV }\end{array}$ & $\begin{array}{c}\text { Ground-Mounted } \\
\text { Axis-Tracking PV }\end{array}$ & $\begin{array}{c}\text { Building-Integrated } \\
\text { Roof-Mounted PV }\end{array}$ \\
\hline $\begin{array}{l}\text { Equipment Cost } \\
\text { Assumptions (\$/kW) }\end{array}$ & $\$ 4,500$ & $\$ 6,500$ & $\$ 3,750$ \\
\hline SIR & 0.32 & 0.29 & 0.37 \\
\hline $\begin{array}{l}\text { Simple Payback } \\
\text { (years) }\end{array}$ & 46.1 & 49.8 & 39.5 \\
\hline $\begin{array}{l}\text { Cost of Electricity at } \\
\text { 10\% IRR (\$/kWh) }\end{array}$ & 33.4 & 36.9 & 28.7 \\
\hline $\begin{array}{l}\text { Variable O\&M } \\
\text { (\$/kWh) }\end{array}$ & 0.0 & 0.0 & 0.0 \\
\hline Fixed O\&M (\$/net kW) & $\$ 12$ & $\$ 12$ & $\$ 12$ \\
\hline
\end{tabular}


Fort Polk should continue to monitor the market conditions affecting solar energy, especially the price of solar RECs. Advances in PV technology are expected to produce less expensive solar cells, although rising demand may negate some of these advances. Rising energy rates may do the most to tip the scales in favor of solar electric.

\section{Ground Source Heat Pump Findings and Recommendations}

The cost-effectiveness of retrofitting existing heating, ventilating, and air conditioning (HVAC) systems with GSHPs on Fort Polk was evaluated using the Facility Energy Decision System (FEDS) building energy modeling program. FEDS analyzed open-loop, horizontal closed-loop, and vertical closed-loop GSHPs for representative buildings on Fort Polk.

At this time, no retrofit GSHP projects were found to be cost-effective for Fort Polk. These findings are driven primarily by the cooling-dominated climate and the low cost of fossil fuel. Most of the savings from a GSHP retrofit are on the heating side, where equipment efficiency increases by a factor of 4 or more. Furthermore, Fort Polk's natural gas prices are low by both historical and regional standards, and GSHPs would mostly be replacing natural gas furnaces for heating. Because the cost of heating is low and the heating season is mild, the overall savings in the heating mode are low. On the cooling side, savings are also low. The widespread use of central chilled water generated by large, high-efficiency chillers at Fort Polk makes GSHP projects even less economic because GSHP cooling efficiency cannot compete.

No near-term retrofits look feasible, but as new construction is planned and designed, GSHPs should be evaluated for life-cycle cost-effectiveness. Detailed results are provided in Appendix D.

\section{Wind Energy Findings and Recommendations}

The wind resource at Fort Polk is not sufficient for an economically feasible wind project. With a wind speed of $4.1 \mathrm{~m} / \mathrm{s}$, a commercial energy cost of $57 \phi / \mathrm{kWh}$ would be required to provide a $10 \%$ IRR, which is an unrealistic rate for Fort Polk to pay or to expect from the sale of renewable energy credits (RECs). Using ECIP funding, the SIR is negative, and the payback is over 150 years (see Table 8). If incentives become available or electricity rates increase, large-scale wind should be re-evaluated. This analysis is detailed in Appendix F.

Table 8: Economic Assessment of Wind Power

\begin{tabular}{|c|c|c|c|c||}
\hline $\begin{array}{c}\text { Financing } \\
\text { Scenario }\end{array}$ & $\begin{array}{c}\text { Energy } \\
\text { Cost } \\
(\mathbf{\$ / k W h})\end{array}$ & IRR & ECIP SIR & $\begin{array}{c}\text { Simple Payback } \\
\text { (years) }\end{array}$ \\
\hline ECIP & 6.87 & $\mathrm{n} / \mathrm{a}$ & negative & 155 \\
\hline IPP & 56.98 & $10 \%$ & $\mathrm{n} / \mathrm{a}$ & $\mathrm{n} / \mathrm{a}$ \\
\hline
\end{tabular}




\section{APPENDIX A}

\section{Business Case Analysis Approach}




\section{Appendix A: Business Case Analysis Approach}

\section{Overall Basis for Project Economic Feasibility}

The renewable projects considered in this analysis need to compare favorably against the future commercial price of electricity purchased by Fort Polk to be economically feasible.

Fort Polk is divided into two primary areas, North Fort and South Fort, and both are served by Entergy Louisiana LLC on the same block-structured schedule. Peak demand is only metered for the purposes of determining the magnitude, in kilowatt-hours, of the first block. Peak demand is the maximum $\mathrm{kW}$ measured over a 15-minute interval and is recorded monthly. The block structure is composed of three different blocks. The energy rate for the first block is $8.258 \phi / \mathrm{kWh}$ per $35 \mathrm{~kW}$ of demand. The energy rate for the second block is $3.867 \phi / \mathrm{kWh}$ for the next $24,500 \mathrm{kWh}$. The energy rate for the third block is $2.005 \mathrm{c} / \mathrm{kWh}$ (November through April) or $2.459 \notin / \mathrm{kWh}$ (May through September) for all remaining kilowatt-hours. The overwhelming majority of Fort Polk's electricity consumption is charged at the third block rate. A fuel surcharge ranging from $2.67 \phi / \mathrm{kWh}$ to $4.57 \phi / \mathrm{kWh}$ and an environmental adjustment charge ranging from $0.01 \notin / \mathrm{kWh}$ to $0.06 \notin / \mathrm{kWh}$ is applied to all kilowatt-hours supplied. Two separate hurricane charges relating to bond repayment for damages caused by Hurricane Katrina apply a percentage-based fee to the bill. The LURC Hurricane Charge was an average of $11.8 \%$, while the Hurricane Offset Charge was an average of $-5.5 \%$. The Hurricane Offset Charge is negative because it reflects Congressional tax credits for electric companies impacted by Hurricane Katrina.

Entergy Louisiana supplied a combined 193,112 MWh between Fort Polk's north and south meters in FY 2009. The south meter supplied 160,273 MWh, and the north meter supplied $32,838 \mathrm{MWh}$. The maximum monthly peak demand for the south meter was $31.4 \mathrm{MW}$ in July while the peak demand for the north meter was 7.1 MW in October. The average demand was 24.2 MW and 5.7 MW for the south and north meters, respectively. The total FY 2009 bill was \$10.5 million and \$2.3 million for the south and north meters, respectively, which totals to $\$ 12.8$ million between the two primary meters.

Typically, solar and wind renewable energy resources displace the direct energy $(\mathrm{kWh})$ charge, while geothermal, biomass, and waste-to-energy need to compare favorably against the average avoided cost (which includes demand charges). However, the rate structure for the north and south meters do not have any demand-related charges. Consequently, the direct energy charge is equal to the average avoided cost. The energy rate used for all energy resources except ground source heat pumps (GSHPs) is $6.87 \phi / \mathrm{kWh}$ for the north meter and $6.74 \phi / \mathrm{kWh}$ for the south meter. The approximately $0.1 \notin / \mathrm{kWh}$ difference originates from differences in consumption patterns and fuel surcharges between the two meters. The GSHP analysis used the detailed timeof-use rate schedule to calculate operational cost savings.

All but one of the analyses was conducted using the Financial Analysis Tool for Electric Energy Projects financial analysis model (FATE2-P), described later in this appendix. The analysis for GSHPs was conducted using the Facility Energy Decision System (FEDS) model, also described in this appendix. 


\section{Analytic Approaches}

In assessing the economic feasibility of renewable energy projects at Fort Polk, PNNL generally evaluated two business case alternatives, (1) investment by an independent power producer (IPP), and (2) Energy Conservation Investment Program (ECIP) funding. These two funding sources have the best returns on Federal investments among the available alternatives. Two other alternatives were examined when conditions were also favorable, (3) the Utility Energy Services Contract (UESC), and (4) the Energy Savings Performance Contract (ESPC).

Under an IPP scenario, an independent power producer will generally fund, construct, and operate a renewable energy facility, selling power into the competitive marketplace and/or directly to the site that hosts the energy project. This scenario is generally economic when the third-party investor can take advantage of substantial Federal and state incentives. The incentives depend on the type of renewable energy generated and may include production tax credits, investment tax credits, substantially accelerated tax depreciation of assets, reductions in sales taxes, and exemption from property tax.

ECIP is one standard DoD approach for making energy efficiency and renewable energy investments using Federally appropriated funding. ECIP investment awards are made based upon savings to investment ratio (SIR) and simple payback criteria. ECIP funding is limited and is awarded on a competitive basis within the Army - only the most economic projects can be assured funding. The approach used in the analyses follows the Federal life cycle cost (LCC) methodology and procedures in 10 CFR, Part 436, Subpart A. The LCC calculations are based on the Federal Energy Management Program (FEMP) discount rates and energy price escalation rates updated on April 1, 2009.

The UESC and ESPC are very similar approaches, where a third party invests in an energy project on the Federal facility in return for a share of the energy savings that result. The major difference is that under an UESC, the third party is a utility - generally the utility providing energy to the Federal facility. Under ESPC, the investment party is a non-utility, generally an engineering firm that specializes in energy projects. Under UESC and ESPC, the third party must be repaid out of each year's operational dollars, and the investment must be repaid within the lifetime of the asset. Generally, UESC is more feasible than ESPC because utilities can obtain capital less expensively than can the ESPC contractor. But not all utilities fund UESC projects, and the types of projects funded may be limited, opening the door for ESPC. UESCs and ESPCs cannot generally capture depreciation or tax incentives that would be afforded an IPP.

\section{Independent Power Producer Assumptions}

In addition to capital and operating costs, project feasibility for the IPP is dependent on federal and state tax incentives, interest rates, inflation rates, and required rates of return discussed in the following sections.

Federal Incentives for Renewable Energy

Federal incentives for renewable energy include investment tax credits for corporations, production tax credits, and significantly accelerated depreciation of equipment. Combining the 
incentives with attractive market prices can, in certain cases, lead to feasible renewable energy projects.

\section{Tax Credits}

Table A-1 shows which tax credits (investment or production) are applicable to which resources, as of the writing of this report. Investment, or business, tax credits provide credits against income tax for qualifying assets. Financial crisis emergency legislation lengthened the investment tax credit period by 8 years to January 1, 2017 (H.R. 1424 2008). The renewable energy production tax credit (PTC) provides a per-kWh-produced tax credit for electricity generated. The PTC has been allowed to lapse and then been renewed several times. All of the analyses assume it will be available when the equipment is placed in service.

Table A-1: Renewable Electricity Generation Tax Credits

\begin{tabular}{|c|c|c|c|c|c|}
\hline & Solar PV & Wind & Geothermal & Biomass & $\begin{array}{l}\text { Municipal } \\
\text { Solid Waste }\end{array}$ \\
\hline $\begin{array}{l}\text { Investment } \\
\text { Tax Credit }\end{array}$ & $30 \%^{1}$ & $\begin{array}{l}30 \%, \text { small- } \\
\text { scale only }\end{array}$ & $10 \%^{3}$ & $10 \%^{3}$ & $10 \%^{3}$ \\
\hline $\begin{array}{l}\text { Production } \\
\text { Tax Credit }\end{array}$ & $\begin{array}{l}\text { Excluded for } \\
\text { equipment placed } \\
\text { in service after } \\
\text { December } 2005^{2}\end{array}$ & $\begin{array}{l}2.1 థ / k^{2} \text { for } \\
10 \mathrm{yrs}^{2}\end{array}$ & $\begin{array}{l}2.1 \$ / \mathrm{kWh}^{2} \text { for } \\
10 \mathrm{yrs}^{2}\end{array}$ & $\begin{array}{l}2.1 \$ / \mathrm{kWh} \text { for } 10 \text { yrs (closed- } \\
\text { loop) }{ }^{2}, 1.1 \$ / \mathrm{kWh} \text { for } 5 \text { yrs } \\
(\text { open-loop) })^{2}\end{array}$ & $\begin{array}{l}1.1 థ / \mathrm{kWh} \text { for } \\
5 \mathrm{yrs}^{2}\end{array}$ \\
\hline Notes & No incentive limits. & & $\begin{array}{l}\text { Both credits } \\
\text { cannot be } \\
\text { taken at the } \\
\text { same time. } \\
\text { No other } \\
\text { incentive } \\
\text { limits. }\end{array}$ & $\begin{array}{l}\text { Both credits cannot be taken } \\
\text { at the same time. Closed- } \\
\text { loop biomass is grown with } \\
\text { the sole purpose of being } \\
\text { used to generate energy; } \\
\text { open-loop is waste } \\
\text { materials. }\end{array}$ & \\
\hline
\end{tabular}

${ }^{1}$ (DSIRE 2009a)

2 (H.R. 6111 2006)

3 (JCT 2007)

Any Federal subsidy used in the financing of the eligible equipment, including tax credits, reduces the tax basis for depreciation (26 USC $\S 48$ ). The basis of the facility is eligible for $50 \%$ of the total energy tax credit taken (JCT 2007).

\section{Depreciation}

Most renewable energy equipment qualifies for significantly accelerated depreciation using the modified accelerated cost recovery system (MACRS). According to 168(e)(3)(B)(vi), most renewable energy production facilities would qualify for 5-year accelerated depreciation (US Treasury 2009).

Table A-2 provides the depreciation rates used in the model for 5-year property. The rates reflect the use of the 3/4-year convention. The basis is reduced by $50 \%$ of any energy investment tax taken (JCT 2007).

Table A-2: MACRS Depreciation Rates for Renewable Energy Projects

\begin{tabular}{|c|c|c|c|c|c||}
\hline Year 1 & Year 2 & Year 3 & Year 4 & Year 5 & Year 6 \\
\hline $35 \%$ & $26 \%$ & $15.6 \%$ & $11.01 \%$ & $11.01 \%$ & $1.38 \%$ \\
\hline
\end{tabular}




\section{Louisiana-Specific Incentives and Taxes}

State incentives for renewable energy in Louisiana include a corporate tax credit and net metering. The tax credit is $50 \%$ of the installed cost up to $\$ 25,000$, or $\$ 12,500$ per system, and applies to PV, wind, and solar thermal. The credit is insignificant in comparison to the costs of the systems evaluated; consequently, they were not included in our analysis. Louisiana's net metering law allows commercial customer generators to net meter up to $300 \mathrm{~kW}$ (DSIRE 2010), which is also relatively small compared to the project sizes being evaluated here.

A sales tax of 4\% (LDR 2010b) was applied where appropriate in this analysis. State corporate income taxes of $8 \%$ were applied to renewable project types that required state income taxes to be applied. Louisiana also has a corporate franchise tax that is applied at the rate of $\$ 1.50$ per $\$ 1,000$ of capital employed for the first $\$ 300,000$ and $\$ 1.00$ per $\$ 1,000$ for amounts above $\$ 300,000$ (LDR 2010a). A property tax rate of $1.4 \%$ was assumed. Vernon Parish's property tax rates were $\$ 108.70$ per $\$ 1,000$ assessed value in 2007 . Beauregard parish property tax rates were similar at \$107.10 per \$1,000 (Synergos Technologies 2009a, b). Commercial property is assessed at $15 \%$ of fair market value. The value is dependent upon the property type, and a schedule indicates the value for each year of life. The average of the franchise tax and property tax is approximately $1 \%$ (Louisiana Code 2009).

\section{Other Independent Power Producer Assumptions}

The minimum after-tax internal rate of return (IRR) used in the analysis of IPP opportunities was $10 \%$. The typical after-tax rate of return for most third-party developers is closer to $15 \%$, but there appears to be a suite of renewable energy developers willing to accept a lower return. Both costs and prices were assumed to escalate with an inflation rate of $1.8 \%$.

\section{Energy Conservation Investment Projects}

The assumptions for ECIP are driven by FEMP. Table A-3 lays out the discount rates underlying the model as of April 2008. The real and nominal rates for DOE/FEMP imply a 1.8\% inflation rate. New discount rates were obtained from Rushing and Lippiatt (2009).

Table A-3: Discount Rate Assumptions in the ECIP Model

\begin{tabular}{|r|c|c|c|c|c|c||}
\hline Discount Rate & DOE FEMP & OMB 3-year & OMB 5-year & OMB 7-year & $\begin{array}{c}\text { OMB 10- } \\
\text { year }\end{array}$ & $\begin{array}{c}\text { OMB 30- } \\
\text { year }\end{array}$ \\
\hline real & $3.0 \%$ & $2.1 \%$ & $2.3 \%$ & $2.4 \%$ & $2.6 \%$ & $2.8 \%$ \\
\hline nominal & $4.8 \%$ & $3.9 \%$ & $4.1 \%$ & $4.2 \%$ & $4.4 \%$ & $4.6 \%$ \\
\hline
\end{tabular}

\section{FATE2-P Model Description}

The FATE2-P (Financial Analysis Tool for Electric Energy Projects) financial analysis model was used to evaluate the feasibility of renewable energy projects at Fort Polk. The spreadsheet model was developed by Princeton Economic Research, Inc. and the National Renewable Energy Laboratory for the U.S. Department of Energy. FATE2-P can be used to develop pro forma financial statements for a utility using a revenue requirements approach or an IPP using the discounted rate of return approach. Both approaches are diagrammed in Figure A-1. Other models produce very similar results given the same inputs. The revenue requirements approach follows a cost-based utility revenue requirements analysis, and the IPP approach uses a marketbased, discounted, cash flow return. The FATE2-P model has been updated by PNNL to include 
the Military Construction (MILCON) ECIP Module in addition to the rate of return methodology. The model has been used to model improved technology designs, resource variability, and favorable tax treatment on renewable energy products. The advantage this model has over other models is that it is already suited for handling all of the renewable energy technologies in this study through one model, thus providing results on a comparable basis across all technologies.
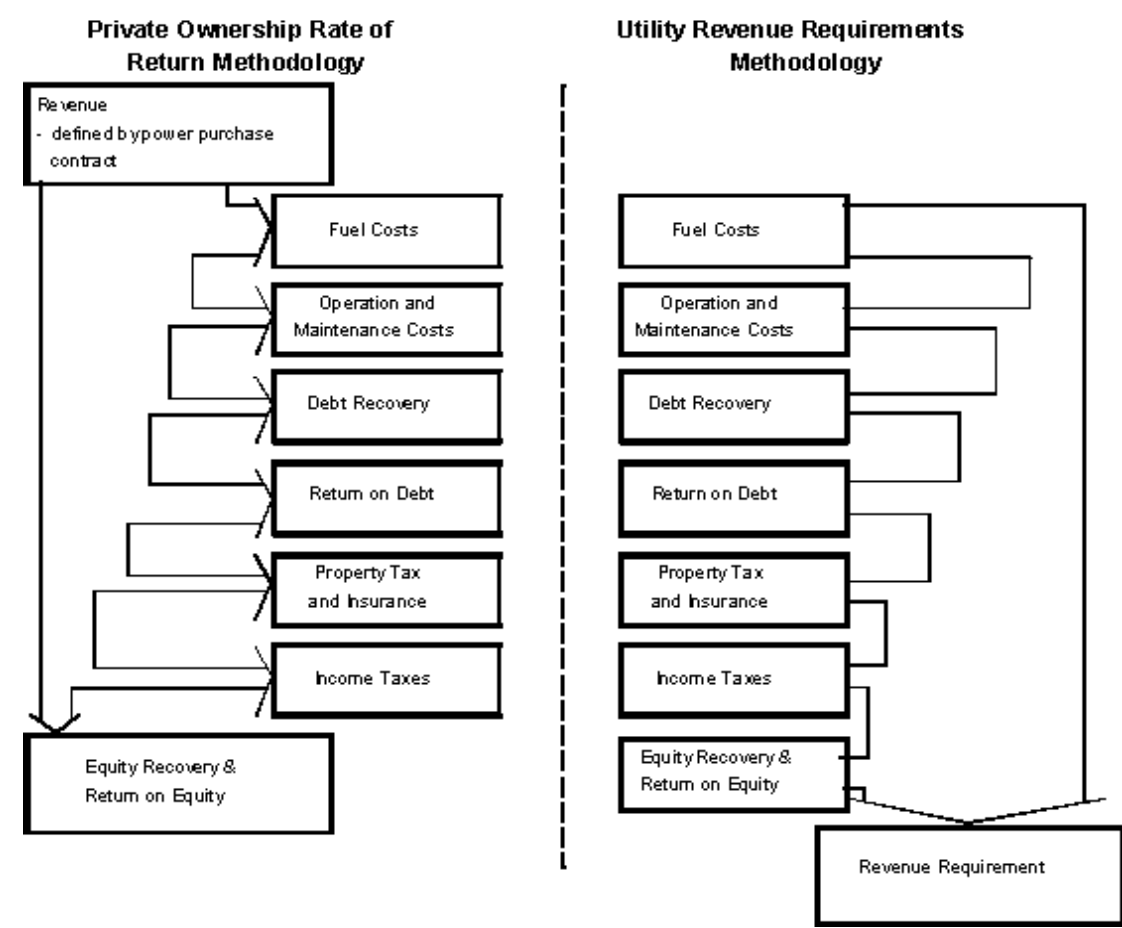

Figure A-1: FATE2-P Methodology

\section{Private Ownership Rate of Return Methodology}

The Private Ownership Rate of Return Module (IPP) develops an annual after-tax cash flow based on the revenues defined in the power purchase contract and costs associated with constructing and operating the generation facility. The goal of this approach is to capture the relevant investment costs after-tax and compare them with the net cash flow from the after-tax investment over time. The model contains sections to capture the relevant costs of construction, including the debt and equity capital accumulation to purchase the investment and the associated payback of debt and equity capital. In addition, the model has sections associated with revenue generation, cash flow, an income statement, and associated statements to calculate tax liabilities to capture after-tax cash flow. The financing section includes several pertinent sections, including sources and uses, construction and debt accumulation, reserve funds requirements, debt schedule, amortization of debt fees, and debt service coverage ratios.

$\checkmark$ The Sources and Uses of Funds section shows the allocation of construction funds between components and sources of those funds. Uses of funds include construction cost, AFUDC (allowances for funds used during construction), and underwriters' fees for both debt and equity. 
$\checkmark$ The construction and debt accumulation statement is capable of handling a 6-year construction period starting at any date. Any construction draw schedule can be used for 1 to 6 years. An equal percentage draw schedule for each year of any given construction length is the default.

$\checkmark$ The model contains major maintenance and debt-service reserve funds. Both types of accounts generate interest income that becomes a part of the income statement through a drawn-off interest calculation. The model does not currently calculate a working capital reserve account. Such an account would add interest costs to the cost statement in addition to the interest costs on the capital investment.

$\checkmark$ The debt schedule allows three types of financing: level payment, bullet, and customized. Level payment financing is customary for projects that have adequate cash flow to satisfy debt coverage payments and are of short duration. Customized financing is required when certain years fall below the minimums set by the investment banking industry.

$\checkmark$ Cash flow statements can be constructed for up to 30 years of revenue generation plus the 6-year construction time frame.

$\checkmark$ The Revenue Module contains a variable capacity factor that must be filled in by the analyst to capture depletion of the geothermal fields or the capacity of wind or the other renewable energy resources. This section also allows for secondary energy byproduct credits (such as for steam if it has value) and up to six different types of subsidy payments, if available. The model also accepts after-tax production credits, if available, and includes interest on reserves.

$\checkmark$ Cash expense statements include standard operations and maintenance (O\&M) costs (both fixed and variable), general and administrative (G\&A), insurance, and land fees. There is a major maintenance expense along with a reserve fund dedicated to covering the major maintenance when it occurs. Up to two different fuel costs can be entered. There is also an entry for royalty fees associated with geothermal.

$\checkmark$ The earnings statement in this model calculates earnings and taxes based on a tax table. Operating income is calculated by subtracting cash and operating expenses from revenue, as described in the section above. Taxable income is determined by subtracting cash and non-cash expenses such as interest, depreciation, amortization of fees, interest during construction (IDC), and depletion allowances. Taxes paid and tax credits received are netted, and after-tax book income is calculated. The net taxes paid become a part of the cash flow.

$\checkmark$ The model includes straight-line and MACRS depreciation approaches with mid-quarter convention depreciation tables. Straight-line allows for the book basis value of assets and liabilities to be calculated while MACRS allows for the taxable basis of the investment.

$\checkmark$ The model amortizes debt-related fees over 15 years and equity organizational fees over 5 years. Equity tax advice is expensed in the first year, and equity broker fees are excluded.

$\checkmark$ The model calculates depletion allowances on geothermal projects. The model also depletes certain AFUDCs when appropriate. 
$\checkmark$ Income tax and other tax statements are prepared for federal and state taxes paid as well as tax credits earned. Tax calculations include excise taxes as well as federal, state, and local taxes. Depreciation calculations used to capture after-tax cash flow can use either straight-line or MACRS. There is also a section to incorporate local property taxes and special tax assessments.

$\checkmark$ The assumptions section is fairly extensive and covers construction costs, debt acquisition, equity acquisition, capacity factors, fixed and variable O\&M inputs, financial factors such as interest rates, G\&A expenses, real escalation in O\&M charges, unfired fuel assumptions, byproduct credits, asset life, inflation rates, tax rates, property tax rates, insurance, investment tax credits, AFUDC, local gross receipts tax, and special property tax assessments.

$\checkmark$ Total plant cost (overnight) is divided into sales tax; rotor, gearbox, generator; tower and civil work; controls, transformer, interconnect; design/engineering; permitting/environmental, construction labor and supervision; contingency; home office overhead; real escalation in construction cost; miscellaneous depreciable cost (last year of construction); sales tax on miscellaneous depreciable cost; land cost; and startup cost.

\section{ECIP Module}

The FATE2-P model also includes a life-cycle cost module based on the Buildings Life-Cycle Cost (BLCC) model (produced by the National Institute of Standards and Technology) and a MILCON ECIP module, which in turn fills out Form 1391. The ECIP module currently reflects 2009 forecast discount and inflation rates. The ECIP module provides values for first-year savings, simple payback, total discounted operational savings, SIR, and adjusted IRR.

\section{The Facility Energy Decision System (FEDS) Model}

FEDS is a building energy modeling software developed by PNNL to support the economic analysis of efficiency technologies at large, multi-building sites. Building characteristics are entered into the model using as much detail as possible, and the model uses the given information to make inferences for the remaining characteristics. Multiple sets of building data can be entered into the same model so that an entire site can be represented at once. The optimization cycle uses data about the location of the site and the energy prices entered into the model to determine cost-effective retrofits for each set of building data and to calculate costs and savings. The suggested retrofits can range from lighting to building envelope to heating, ventilation, and air conditioning (HVAC), covering all aspects of a building's energy use and considering interactive effects. In addition, the model can be adjusted to consider just one type of retrofit. In this renewable analysis conducted at Fort Polk, GSHPs were the only technology analyzed. 


\section{Business Case Analysis References}

DSIRE. 2009. "Federal Incentive for Renewables and Efficiency: Business Energy Tax Credit." Accessed February 2009 at http://www.dsireusa.org/library/includes/incentive2.cfm?Incentive Code=US02F\&State=federal \&currentpageid=1\&ee $=1 \&$ re $=1$.

DSIRE. 2010. "Louisiana: Incentives/Policies for Renewables \& Efficiency.” Accessed February 2010 at http://www.dsireusa.org/incentives/index.cfm?re $=1 \& e e=1 \& \mathrm{spv}=0 \& \mathrm{st}=0 \& \mathrm{srp}=1 \&$ state $=$ LA.

H.R. 1424. 2008. "Emergency Economic Stabilization Act of 2008. "Enrolled Bill.” Accessed October 2008 at http://www.govtrack.us/congress/billtext.xpd?bill=h110-1424.

H.R. 6111. 2006. "Tax Relief and Health Care Act of 2006" (Enrolled as Agreed to or Passed by Both House and Senate). Section 207. December 2006. Accessed at www.cms.hhs.gov/PQRI/Downloads/PQRITaxReliefHealthCareAct.pdf.

JCT—Joint Committee on Taxation. 2007. Description of the Chairman's Modification to the Provisions of the "Heartland, Habitat, Harvest and Horticulture Act of 2007" (JCX-96-07). Accessed at http://www.jct.gov/publications.html?func=select\&id=19.

LDR — Louisiana Department of Revenue. 2010a. "Corporation Income and Franchise Taxes." Accessed on February 23, 2010 at http://revenue.louisiana.gov/sections/business/corp.aspx.

LDR—Louisiana Department of Revenue. 2010b. "Sales Tax." Accessed on February 23, 2010 at http://revenue.louisiana.gov/sections/faq/default.aspx?type=GEN\&cat=SLS\#faq-101.

Louisiana State Code. 2010. "Chapter 25 General Business Assets." Accessed on February 23, 2010 at http://www.lafayetteassessor.com/TopicsPDFs/Louisiana $\% 20$ Property $\% 20$ Tax $\% 20$ Basics $\% 20 \mathrm{bo}$ oklet\%203.pdf.

Rushing, AS and BC Lippiatt. 2009. Energy Price Indices and Discount Factors for Life-Cycle Cost Analysis - April 2009. NISTIR 85-3273-23 (Rev. 5/09). US Department of Commerce, National Institute for Standards and Technology, Washington D.C.

Synergos Technologies, Inc. 2009a. "Beauregard Parish Quick Facts Profile.” Accessed on February 23, 2010 at http://www.louisianasiteselection.com/cleda/ProfileReport.aspx?rpt=QuickFacts\&parish=beaure gard.

Synergos Technologies, Inc. 2009b. "Vernon Parish Quick Facts Profile.” Accessed at http://www.louisianasiteselection.com/cleda/ProfileReport.aspx?rpt=QuickFacts\&parish=Vernon 
United States Code. "26 USC § 48. Title 26. Internal Revenue Code. Subtitle A - Income Taxes. Chapter 1 - Normal Taxes and Surtaxes. Subchapter A - Determination of Tax Liability. Part IV - Credits Against Tax. SubPart E - Rules for Computing Investment Credit.”

United States Code Service. 2006. "16 USC § 796 (2006). Title 16 - Conservation. Chapter 12-Federal Regulation and Development of Power. Subchapter 1 - Regulation of the Development of Water Power and Resources. Definitions."

United States Code Service. 2006. "26 USC § 168 (2006). Title 26. Internal Revenue Code. Subtitle A - Income Taxes. Chapter 1 - Normal Taxes and Surtaxes. Subchapter B Computation of Taxable Income. Part VI - Itemized Deductions for Individuals and Corporations."

U.S. Treasury-United States Department of the Treasury. 2009. Publication 946: How to Depreciate Property. Internal Revenue Service. Washington, D.C. Accessed at http://www.irs.gov/app/picklist/list/publicationsNoticesPdf.html (last updated April 26, 2010). 


\section{APPENDIX B}

\section{Analysis of Biomass and Waste-to-Energy Opportunities}




\section{Appendix B: Analysis of Biomass and Waste-to-Energy Opportunities}

\section{Biomass and Waste-to-Energy Technology}

The term "biomass" refers to renewable fuels used for power production that include agricultural waste, forest and wood processing waste, animal waste, industrial waste, dedicated biomass crops, and methane from landfills and wastewater treatment plants. Waste-to-energy (WTE) is similar, but includes municipal solid waste (MSW) and construction and demolition (C\&D) waste as fuel sources. These feedstocks qualify as renewable sources for Energy Policy Act of 1992 (EPAct) compliance purposes, but some state and alternative goals have different feedstock requirements. While biomass and WTE projects may be very different as to their sources, fuel collection modes, and fuel cost profiles, in the end, energy production often relies on similar technologies.

The primary technologies for producing electricity rely upon steam turbines, gas turbines, or combined cycle turbine generators. Generators are energized by steam produced from direct combustion of raw material or a synthetic gas (syngas) produced through anaerobic digestion or gasification. Direct combustion and anaerobic digestion technologies are mature and have been proven commercially. Gasification technologies are newer to the market, but are promising, based on a number of successful installations. Anaerobic digestion is widely used, but primarily for smaller applications in rural and municipal projects rather than large commercial installations.

Combustion systems burn biomass to produce steam in a boiler, turning a turbine connected to a generator. This method of producing electricity is quite inefficient, at about 20 to $30 \%$. In these systems, combustion products tend to form deposits on the heat transfer surfaces, increasing maintenance requirements and decreasing the lifetime of these surfaces as a result of corrosion and erosion. Ash has to be collected and removed from the system. The variability of incoming feedstock in terms of its composition and moisture content can present problems in combustion systems, most notably with MSW and mixed feeds. Systems that use a more homogeneous feedstock benefit from more complete combustion, which increases efficiency and reduces combustion waste products and emissions. Various boiler designs try to address these issues.

Gasification is more efficient than combustion, but the technologies employed are not as mature or common in commercial operation. The two basic types of gasification are direct-fired (aerobic) and indirect-fired (anaerobic). Gasification uses oxygen (direct-fired systems only), steam, heat, and pressure to break down organic materials to produce syngas, which is primarily hydrogen and carbon monoxide. Syngas is cleaned to remove impurities; then it is used to generate electricity in a gas turbine or fuel cell or to produce transportation fuels and/or commercially valuable chemicals. The syngas resulting from direct-fired systems has a lower heating value than the syngas from indirect-fired systems and requires significant upgrading and processing to be used as fuel. The inorganic materials are discharged as inert solids that can often be used for another purpose. There are many types of gasification designs that use different amounts of oxygen and steam at different stages and temperatures, producing different amounts of waste heat, syngas, and solids. 
Plasma melting is one gasification process just now entering the commercial market for use with MSW. Although it has a short track record, it is worth considering because of its positive attributes for use on a military facility. The plasma melter uses a plasma torch to decompose the material being gasified, resulting in a much higher temperature and more complete reaction. This new technology produces only syngas from the organics, molten metal from any metals, and a hard glass-like substance from the inorganics. Gaseous emissions are released and scrubbed to remove pollutants, and the solid waste can be sold and used for other commercial purposes, such as construction material. Ash collected from syngas cleaning can be fed back into the plasma melter. Hazardous materials can also be gasified in this process, sealing the toxic substances into the solid waste with no potential for leaching (EvTec 2002).

Digesters tend to be smaller systems and are typically used just for biomass. They are usually located at the biomass source, such as farms with significant amounts of animal manure and wastewater treatment facilities. Digesters break down biomass in warm, wet environments to produce methane, which can be captured as fuel for generating electricity. Aerobic digesters are common in developing countries for producing heating and cooking fuel in rural areas.

Anaerobic digesters limit the amount of oxygen in the gasification process, producing gas with a higher concentration of methane, which is better for power production. Because of the smaller size of digester systems, electricity is typically generated with fuel cells, microturbines, or reciprocating engines.

Methane is also produced through anaerobic digestion in landfills as the garbage underground breaks down. It has been left in the ground, but the risk of fire and greenhouse gas emissions has led the Environmental Protection Agency (EPA) to require landfills to remove the methane. The methane could be used in an electricity generation system if the economics are positive. The most economic opportunities for landfill methane capture and use are in cases where the landfill already has a collection system in place, is active or recently closed (methane production tapers off as landfills age), and has sufficient waste (typically at least 1 million tons) to generate a significant amount of methane. The landfill must be lined as well to prevent water intrusion into the landfill that stifles digestion of the waste and methane production, and to prevent the methane from migrating into the surrounding soil. New landfills are typically lined by regulation; many older ones are not. Methane production even from large landfills is relatively low; as a result, power facilities that use it are typically small systems located onsite that use fuel cells, microturbines, or reciprocating engines.

For all of these technologies, except landfill gas, a power plant will require feedstock storage space, feedstock preparation equipment, feed equipment, processing equipment, product cleaning and collection equipment, electricity generation equipment, ash and waste storage space, water for steam and cooling, and emissions control equipment. The specific infrastructure and space required for each of these depends on the type of feedstock and process used, the amount of feedstock used, and existing site conditions. As an example, one plasma gasification project evaluated could process 250 tons of MSW per day in an 80-foot by 175 -foot area, not including storage space. However, permanent systems with infrastructure typically need up to 5 acres.

Some feedstocks require year-round storage because they are only available seasonally (e.g., crop residue); some feedstocks are available almost continuously and require less storage space (e.g., MSW). A feedstock available continuously may need about 20 days of fuel stored in case 
of supply interruption, which can use about 40 acres of land, depending on the overall size of the plant. Most plants only store 3 to 5 days of fuel onsite, requiring about 4 to 5 acres. Feedstocks available only once or twice a year will need hundreds of acres of land. Some feedstocks can be compressed into uniform-sized pellets to simplify storage, transport, and combustion. However, the pelletization can add $20 \%$ to fuel costs. Storage areas may have to be located some distance away from the plant because of site constraints, but nearby storage is preferred to reduce operational costs.

Emissions control requirements depend upon the process used and on regulations affecting the site. Some gasification processes (with gas scrubbers) produce no criteria pollutants, such as $\mathrm{SO}_{\mathrm{X}}$ and $\mathrm{NO}_{\mathrm{X}}$. However, air emissions are inevitable if the resulting syngas is burned in a conventional power generator. Emissions from any power-producing facility will be an environmental concern. Consideration will have to be made regarding the approach to any proposed project. Plants owned and operated by third parties will qualify for separate permitting, and so that may be the best opportunity for Fort Polk.

The capital cost of biomass plants ranges from about $\$ 1,500$ to $\$ 7,000 / \mathrm{kW}$, depending upon scale and specific technologies used (Aabakken 2006). Smaller projects cost much more, resulting in higher energy costs, while larger projects cost less per $\mathrm{kW}$, resulting in more affordable energy costs. Direct combustion technologies tend to be both larger and less capitalintensive than those based on syngas. Digesters tend to have a higher unit cost, primarily because of their smaller size. Operation and maintenance (O\&M) for digesters is also more expensive, costing about $2.0 \phi / \mathrm{kWh}$, compared to about $1.0 \phi / \mathrm{kWh}$ for combustion plants (Aabakken 2006). The advantage for digesters is the low cost of fuel, which is typically free local waste (e.g., sewage sludge, manure).

Even a "free" feedstock such as crop waste, which is not currently collected nor located at one site, does not guarantee a successful project, because collection, transportation, and storage costs can be, and often are, economically prohibitive. The economics of MSW projects are typically more attractive than other biomass projects because fuel is often delivered free or even accompanied by payment in the form of a tipping fee. Most landfills are operated or franchised by a local government. Many of these derive operating revenues from fees that are added to the actual operating costs of the landfill. As a result, the tipping fee may be inflated over actual costs and therefore not an accurate representation of costs that can be avoided.

\section{Biomass and Waste-to-Energy Analysis Approach}

The critical factor in determining feasibility for biomass energy generation is feedstock availability. There are a number of potential feedstocks that were evaluated for use at Fort Polk. The following questions were asked about each feedstock:

- Does this material exist in the surrounding region within 60 miles? (The maximum economic transport distance is assumed to be 30 to 60 miles.)

- How much is available within this area, on average? Is availability constant or variable, depending on crop rotation cycles and/or market conditions? 
- How much is available for use as a feedstock? Availability is based on the feedstock being able to be collected and the lack of competing uses or markets. For example, wheat straw is typically left in the field to protect and rebuild the soil. If it is collected, the resulting bales may have higher value as animal bedding than as fuel, creating a competing market for what was otherwise a waste material on the ground.

- How much electricity can be produced from the available biomass? This is a function of the quantity of material available, moisture content, and its relative heat value.

In this analysis, if the power available from a feedstock were less than $1 \mathrm{MW}$, it was not considered a feasible resource. The narrowed list of possible feedstocks was then evaluated on a simple economic basis. Feedstock costs were estimated based on tipping fees, collection costs, transportation costs, current market rates, and other relevant information. Other operational costs and construction costs were estimated by scaling existing plant data for the three primary technology types. Based on the amount of feedstock available and the size of plant required, a levelized cost of electricity was estimated for each.

For any options that are reasonably close to being cost-effective, further economic analysis was completed, including evaluating tax credits, other incentives, different financing options, and ranges of feedstock sources and amounts. Fort Polk's average electricity cost of $6.74 \phi / \mathrm{kWh}$ was used as the target cost of electricity for this economic analysis.

PNNL staff created a new tool that supports analyses of various plant sizes, costs, and fuel sources in a generic manner. This facilitates "what if" analyses where critical information about fuel source and cost is unavailable. The result is an estimate of what power from a project would cost using available data and staff assessments for missing data. It also allows staff to reverse engineer an answer using Fort Polk's power cost as a given. Specifically, the tool can be set up to provide an estimate of what size plant and fuel cost are needed to produce power for less than the current and projected future power rate. Data from a 2003 National Renewable Energy Laboratory (Bain et al. 2003) study of biomass fuels was used to initiate the analytic tool. The 2003 study costs were converted into 2009 dollars and scaled according to varying plant sizes following the methodology used in the study. Any size plant can be evaluated, and any value can be varied to test for financial feasibility. The tool was only used for preliminary screening because it does not address taxes or incentives. These economic factors have a significant impact on project feasibility, especially if the power project will not be owned and operated by the government.

If the analysis resulted in highly uneconomic estimated costs, the option was rejected. For any options that appeared to be reasonably close to cost-effective in the screening tool, further economic analysis was completed, including evaluating tax credits, other incentives, different financing options, and ranges of feedstock sources and amounts. Any risks or potential issues associated with these remaining project options were noted to present all considerations surrounding an implementation decision. When possible, these were quantified.

\section{Biomass and Waste Resource Characterization}

The following biomass and waste types were assessed for potential as feedstocks. 
- Agricultural (crop residues, animal waste, dedicated biomass crops)

- Forest (thinnings, logging slash)

- Industrial (mill residue, other industry waste)

- Waste (MSW, C\&D waste, landfill gas, biogas or biosolids from wastewater treatment plants).

\section{Agricultural Biomass}

The U.S. Department of Agriculture (USDA) has a database of agricultural production information by county and state. Information was gathered here about crop and livestock production.

\section{Crop Residue}

Crop residues are the plant remains in the field after harvest. Some crops have more residues than others; some, like hay, have no residues at all because the entire plant is harvested. A certain amount of residue left on the soil minimizes erosion, maintains nutrients in the soil, and can provide habitats for game animals. However, too much residue can inhibit the growth of a new crop. Depending on tilling practices, climate, crop type, soil type, and slope of the land, residue may or may not be available for removal. In general, conventional till practices need more residue than no-till practices; warm wet climates need more residue than cold dry climates; corn fields need more residue than wheat fields; coarse, well-drained soils need more residue than poorly drained, heavy clay soils; and steeper slopes need more residue than flat land. In addition, crop residue availability is dependent on competing uses, like cattle feed, and seasonal yields, which can change dramatically from year to year.

In 2008 in counties within 60 miles of Fort Polk, the major crops harvested that leave residues were wheat, corn, sorghum, and cotton (NASS 2009). See Table B-1 for the number of bushels and amount of residue produced on an annual basis. Available residue for biomass energy generation will be somewhere between these values and zero. A rule of thumb is that about $30 \%$ of the residues can be collected. However, these numbers will have to be verified on a farm-byfarm basis for a more accurate analysis.

Table B-1: Crops and Biomass Production near Fort Polk

\begin{tabular}{|l|c|c|c|c||}
\hline \hline & Bushels Produced & $\begin{array}{c}\text { Tons Residue } \\
\text { Remaining }\end{array}$ & $\begin{array}{c}\text { Tons Collectable } \\
\text { Residue }\end{array}$ & $\begin{array}{c}\text { Potential Electricity } \\
\text { Generation (MW) }\end{array}$ \\
\hline Wheat & 545,000 & 27,821 & 8,346 & 1.0 \\
\hline Corn & $3,012,000$ & 83,353 & 25,006 & 3.0 \\
\hline Sorghum & 716,000 & 17,900 & 5,370 & 0.6 \\
\hline Cotton & 15,900 (bales) & 1,590 & 1,431 & 0.2 \\
\hline Total & $\mathbf{4 , 2 8 8 , 9 0 0}$ & $\mathbf{1 3 0 , 6 6 4}$ & $\mathbf{4 0 , 1 5 3}$ & $\mathbf{4 . 8}$ \\
\hline
\end{tabular}

It would cost about $\$ 10 /$ ton to transport the residues to the plant, and about $\$ 10 /$ ton for the farmer's collection effort. Therefore, the crop residue feedstock cost is about $\$ 20 /$ ton. Using all crops together to gain the most benefit from economy of scale, the most cost-effective biomass 
option would be gasification, producing electricity at $14.3 \notin / \mathrm{kWh}$. This is more expensive than Fort Polk's average electric rate $(6.74 \varnothing / \mathrm{kWh})$, making it an unattractive option to pursue at this time.

Furthermore, crop residue may not be a reliable energy resource because of varying crop yields and alternative markets. Availability is dependent on seasonal yields, which can change dramatically with crop rotation, market conditions, and weather patterns. Availability is also dependent on competing uses, including livestock feed, which often pays almost \$42/ton for corn stover and over $\$ 21 /$ ton for wheat straw (Gallagher 2003), and may be located closer to the source. Therefore, it is not recommended to pursue wheat, corn, barley, or cotton residues at this time.

\section{Animal Waste}

Manure from cattle, swine, and poultry farms is generally reclaimed from animal housing and feeding areas and used as fertilizer for crops. This has become a problem because of overapplication. Bad odors and groundwater contamination are forcing farmers to find other ways to dispose of manure. Furthermore, greenhouse gas emissions are now more strictly regulated, so emissions from manure must be controlled. Anaerobic digestion technologies can turn wet manure into energy, and often can be used with existing collection and treatment systems. Poultry waste can be used directly in combustion or gasification systems because it has lower moisture content than cow or swine manure.

However, in 2008 there were no known swine or poultry farms in the area, according to the USDA National Agricultural Statistics Service. All of the cattle reported were either beef cattle or pastured (NASS 2009). In general, it is safe to assume that all beef cattle are pastured as well. Manure in pastures is not good feedstock material because it is not typically collected (increasing the costs and decreasing the heating value as it dries in the field). Only the manure from cattle on a feedlot can be assumed to be available for electricity generation. Therefore, using animal waste as a feedstock for electricity generation is not viable at this time.

\section{Dedicated Crops}

The most common dedicated energy crops include switchgrass, hybrid poplar, willow coppice, and other short rotation woody crops (SRWCs). Energy crops are fast-growing plants that can be harvested for use as energy in various forms. Switchgrass is a native prairie grass that grows best in warm dry climates like the Midwest. SRWCs need lots of water and do well in colder climates like the Northeast. They need at least 16 inches of rainfall per year or need to be located on a body of water. Using dedicated crops as biomass is an option, but they are not always a readily available resource. Rather, agricultural land where the crops can be grown is the resource to be evaluated, and the feedstock cost would be based on the cost to farm that land, harvest the resource, and deliver it to the generation plant on post.

Switchgrass and hybrid popular are the most likely energy crops that would grow well near Fort Polk. According to De La Torre Ugarte et al. (2003), the production costs of switchgrass in the Fort Polk region would range from $\$ 17.87 /$ ton to $\$ 23.70 /$ ton, with an average of $\$ 18.90 /$ ton . Hybrid poplar production would range from $\$ 23.95 /$ ton to $\$ 30.13 /$ ton, averaging $\$ 26.88 /$ ton. To use this material in a biomass plant onsite, a transportation cost of $\$ 10 /$ ton would be added to the production cost. In addition, compensation for the farmer would be required, unless Fort Polk 
produced the energy crops itself. Fort Polk has a lot of land; however, much of it is training land, and a large portion is owned by the Forest Service. Growing and harvesting energy crops would also interfere with Fort Polk's responsibility for wildlife management and the existing bio-diversity commitment with the state of Louisiana.

Switchgrass would be the most economic feedstock choice; at this price with no compensation, it would require a $200-\mathrm{MW}$ gasification plant to generate cost-effective electricity (at $6.74 \varnothing / \mathrm{kWh}$ ), using over 900,000 tons of switchgrass per year. Because of the price volatility, unreliable sources, and necessary utility involvement, dedicated energy crops are not a feasible biomass option.

\section{Forest Thinnings and Logging Slash}

Logging slash includes branches, stumps, and other material that is generated during logging practices but left behind because it is not useful to the loggers seeking large tree trunks. Once this slash is cut and left on the forest floor, it dries out, becoming good fuel for fires. It also can get in the way of machinery during replanting efforts. Sometimes it is gathered into small piles and burned in a controlled manner to reduce the risk of widespread forest fire, but this practice pollutes the air and may be restricted by air quality regulations. Instead, it can be collected and transported to a biomass facility where the emissions can be controlled and the wood waste can be used to generate energy.

Forested land covers much of Fort Polk. Environmental concerns, including preservation of habitat for the red cockaded woodpecker and Fort Polk's bio-diversity commitment to the state of Louisiana, limit timber harvesting and forest management activities. The only tree species currently remediated is the long-leaf pine, which requires burning to encourage healthy forests. The forestry department has a requirement to burn 21,000 acres of long-leaf pine every 3 years, and all other wood waste and forest slash are left on the ground to improve soil quality.

Consequently, Fort Polk's woody biomass resource is not available for use (Stagg et al. 2010).

Forested areas near Fort Polk produced 392,451 tons of collectable slash in 2007 (Forest Service 2009), assuming a 50\% recovery factor. Most of this regional biomass wood waste (except roughly $2 \%$ ) is currently consumed by the Boise Cascade paper mill in Deridder and numerous plywood and lumber mills in the area (O’Dell et al. 2010).

It would cost about $\$ 10 /$ ton to transport this offsite wood waste to an onsite biomass plant and about $\$ 2 /$ ton for the collection effort, for a total of $\$ 12 /$ ton (Haq 2002). If the offsite slash were available for a biomass plant on Fort Polk, about $57 \mathrm{MW}$ could be generated at $7.69 \phi / \mathrm{kWh}$, which is close to Fort Polk's current rate. The economics are marginal, and the likelihood that any of these resources will become available depends on the market conditions for the Boise mill and the other wood product industries in the region. A strong regional demand for biomass resources elevates the acquisition costs, resulting in a higher cost of electricity. Furthermore, Fort Polk consumes an average of $30 \mathrm{MW}$, so construction of a much larger plant onsite is not likely to be supported. A smaller plant reduces the benefit of economies of scale, again increasing the cost of generated electricity. The use of waste heat would positively impact the economics, so if wood waste becomes available in the area, a cogeneration project could be explored. At the current time, it is not recommended to pursue wood waste. 


\section{Industrial Biomass}

Industrial biomass includes mill residue, food processing waste, textile waste, or waste from other specialized operations. There are many types of mills that use wood to produce various products, including lumber, shake and shingle, pulp, veneer and plywood, log chips, and posts, poles, and pilings. These processes generate waste in the form of sawdust and wood pieces, which are useful materials. In fact, most mill residue is currently used for fiber, fuel, or other uses.

Mills do exist in the area surrounding Fort Polk, but the majority of the byproducts are used for other purposes, primarily fiber and fuel. Unused mill residues within 60 miles of Fort Polk measured 14,368 tons in 2007 (Forest Service 2009). Assuming that costs are similar to forest slash, mill residue would cost about $\$ 12 /$ ton for collection and transportation. By using unused mill residues, about 2.1 MW could be generated at $19.90 \notin / \mathrm{kWh}$, which is much higher than the rate Fort Polk currently pays. In addition, mill residue typically must be pelletized before use in a biomass plant, which reduces the cost-effectiveness further. Therefore, using mill residue is not an option worth pursuing at this time.

There are no other large industrial facilities in the Fort Polk area that generate waste usable for biomass.

\section{Waste Biomass}

Municipal Solid and Urban Wood Waste

MSW and C\&D waste are being generated at greater rates each year while landfills are filling up, resulting in greater hauling distances and increasing prices for waste disposal. Recycling is one way to reduce the strain on landfills; using the waste to generate energy is another. Some recyclables, like metals, must be separated out before waste is used for energy generation. All carbon-based materials, however, can be used to generate energy.

Fort Polk's cantonment area produced 6,959 tons of MSW during FY 2009. Additionally, the training areas generate 185 to 190 tons per rotation of MSW "field trash" that is separated from munitions at the Solid Waste Sorting Facility. The number of rotations can vary each year depending on funding. Peak years have 12 rotations, and low years will have 6 rotations. This provides an additional source of MSW ranging from 1,110 to 2,280 tons/year. This analysis assumes Fort Polk generates a conservative amount of 8,069 tons of MSW per year. The current waste contract is handled by Red River Services, and all site waste is disposed of at the landfill in Many, Louisiana. Family Housing is privatized, and the contract is handled by Picerne (Gibson and Fitzgerald 2010). Waste quantities were not available, but could be included if a WTE facility is pursued.

There are operating landfills within 60 miles of Fort Polk in Oakdale, Many, and Welsh. Waste disposed of in this area totals about 556,243 tons per year (LDEQ 2007) and is expected to remain constant in the future. These landfills are summarized, with their respective tipping fees, in Table B-2. 
Table B-2: Waste near Fort Polk

\begin{tabular}{|c|c|c|c|c|c|c|}
\hline Site & $\begin{array}{l}\text { Collection } \\
\text { Location }\end{array}$ & $\begin{array}{l}\text { Miles } \\
\text { from } \\
\text { Polk }\end{array}$ & $\begin{array}{l}\text { Tipping } \\
\text { Fee (\$) }\end{array}$ & $\begin{array}{l}\text { Assumed } \\
\text { Cost } \\
\text { Savings (\$) }\end{array}$ & $\begin{array}{c}\text { Available } \\
\text { MSW } \\
\text { (tons/year) }\end{array}$ & $\begin{array}{c}\text { Potential } \\
\text { Electricity } \\
\text { Generation } \\
\text { (MW) }\end{array}$ \\
\hline Fort Polk & Fort Polk, LA & 0 & 21.00 & 21.00 & $8,069^{*}$ & 0.9 \\
\hline Timberlane Landfill & Oakdale, LA & 37 & 27.69 & 13.84 & 112,863 & 12.4 \\
\hline Sabine Parish Landfill & Many, LA & 39 & 27.69 & 13.84 & 81,715 & 9.0 \\
\hline $\begin{array}{l}\text { Jefferson Davis Parish } \\
\text { Landfill }\end{array}$ & Welsh, LA & 58 & 20.10 & 10.05 & 361,665 & 39.6 \\
\hline \multicolumn{5}{|r|}{ TOTAL } & 564,312 & 61.9 \\
\hline
\end{tabular}

* This value combines the site cantonment generation of 6,959 tons/year and the conservative generation of 1,110 tons/year from the Solid Waste Sorting Facility.

The assumed cost savings for each site is discounted 50\% from the tipping fee to account for any additional transportation needs and incentives to deliver waste to a new location. Tipping fees fund recycling programs and other waste management operations, so the city or county would want to retain a portion of the revenue to continue operating these programs.

Fort Polk's waste and all waste in the area were evaluated here as potential sources of feedstock. Depending on contracts, plans, capacity needs, and economic issues at each landfill or transfer station, none or all waste may actually be available. According to a New Orleans local news article from the beginning of 2009 (Rainey 2009), Jefferson Davis Parish Landfill is in active discussion to send all or portions of its waste elsewhere. Additionally, the Sabine Parish Landfill is known to have less than 10 years of capacity remaining (LDEQ 2009), making both of the waste streams attractive to pursue.

Commercial C\&D waste is often primarily composed of concrete, asphalt, or other materials that do not break down easily; thus, it is typically not available for energy generation. Fort Polk generates approximately 1,300 tons of $C \& D$ waste annually, which is largely free of concrete and non-combustible materials (Gibson and Fitzgerald 2010). It is currently hauled to Shammerhorn C\&D Waste, but could be diverted as an additional fuel feed source if a biomass or WTE facility is pursued. The rest of the waste stream flowing to Shammerhorn may also be available; however, the other sources of $C \& D$ waste may have large quantities of noncombustible materials. This would need to be verified with the management at Shammerhorn C\&D Waste, and the resource may require additional separation equipment to remove noncombustible materials. If a WTE project is pursued and additional sources of waste are needed, then $\mathrm{C} \& \mathrm{D}$ waste should be re-evaluated as a feedstock, keeping in mind that there could be additional costs associated with separating the feedstock into useful combustible materials and unusable noncombustible materials.

The technologies considered for waste conversion include combustion and gasification, and some options were found to be cost-effective in the screening analysis. See the Findings section below for the economic analysis of using MSW for electricity generation. 
Landfill Gas

Methane generated from decomposing waste is a combustible pollutant that must be controlled. It is typically vented or collected and flared to avoid buildup and danger of explosion. Collected methane can be used as a fuel to generate heat or electricity.

There have been no active landfills at Fort Polk for 20 years. The original landfill was opened in 1941 and closed in the early 1970s. Two smaller, more recent landfills were closed in 1986 and 1992, but they were no more than 30 and 12 acres in size and only open for 6 and 5 years, respectively (Stagg 2010). None of these are good candidates for landfill gas. Additionally, there are no landfills within a reasonable distance to pursue an external source of landfill gas, making this resource unavailable at this time.

\section{Wastewater Treatment Plant Sludge}

Wastewater treatment plant (WWTP) sludge is what remains after wastewater is treated, and the clean water is returned to the ground or other body of water. It has high energy content when dried, but the drying process is energy-intensive and necessary before transportation. Sludge is similar in substance to manure; it is a very watered-down substance that is best processed onsite, where methane is generated with anaerobic digestion. Therefore, only onsite sources of sludge are reasonable to use for energy generation.

Because wastewater produced at Fort Polk is sent offsite for treatment, there is no sludge available for use as a feedstock.

\section{Biomass and Waste-to-Energy: Economic and Other Analysis Parameters}

Data used in this analysis were obtained from local sources when possible, and the economic assumptions were generally conservative. Our assumptions are presented in the report. However, any significant changes to important assumptions may change outcomesopportunities that are marginally economic in this report may no longer be economic if the values are changed significantly.

Biomass and WTE options were analyzed using Energy Conservation Investment Program (ECIP) and independent power producer (IPP) funding scenarios. The cost-effectiveness for ECIP projects is determined with savings-to-investment ratio (SIR) values, and the internal rate of return (IRR) shows whether the IPP scenario is cost-effective. The economic assumptions used to analyze each scenario, including available incentives, are listed in Table B-3. The assumptions that vary per scenario are listed below with the results. The average cost of electricity that Fort Polk would pay for the renewable energy was assumed to be $6.74 \notin / \mathrm{kWh}$. 
Table B-3: Economic Assumptions, Constant \$2009

\begin{tabular}{|c|c|}
\hline \multicolumn{2}{|l|}{ Economic Factors } \\
\hline Inflation & $1.2 \%$ \\
\hline Interest Rate & $10.0 \%$ \\
\hline Debt/Equity Ratio & N/A \\
\hline Real Discount Rate & $3.0 \%$ \\
\hline \multicolumn{2}{|l|}{ Tax Considerations } \\
\hline Federal Depreciation & MACRS \\
\hline Federal Tax Rate & $35 \%$ \\
\hline State Income Tax Rate & $8.0 \%$ \\
\hline State Sales Tax & $4.0 \%$ \\
\hline Property Tax Rate & $1.0 \%$ \\
\hline \multicolumn{2}{|l|}{ Incentives } \\
\hline Federal Production Tax Credit & $\$ 0.011 / \mathrm{kWh}$ \\
\hline State Production Tax Credit & $\$ 0.00 / \mathrm{kWh}$ \\
\hline Federal Energy Tax Credit & $0 \%$ \\
\hline State Energy Tax Credit & $0 \%$ \\
\hline Utility Rebate & $\$ 0 / \mathrm{kW}$ \\
\hline \multicolumn{2}{|l|}{ Technology } \\
\hline Plant Life* & 30 years \\
\hline $\begin{array}{l}\text { Capacity Factor (basis net kW } \\
\text { output): Total System** }\end{array}$ & $85 \%$ \\
\hline $\begin{array}{l}\text { Real Escalation in } \\
\text { Construction Cost }\end{array}$ & $0 \%$ \\
\hline $\begin{array}{l}\text { Misc. Depreciable Cost (last } \\
\text { year of construction) }\end{array}$ & $\$ 0$ \\
\hline $\begin{array}{l}\text { Sales Tax on Misc. } \\
\text { Depreciation Cost }\end{array}$ & $\$ 0$ \\
\hline Land Cost & $\$ 0 / \mathrm{kW}$ \\
\hline Startup Cost & $\$ 0 / \mathrm{kW}$ \\
\hline
\end{tabular}

\section{Findings: Biomass and Waste-to-Energy Opportunities}

The availability of crop residue, animal waste, mill residue, other industrial waste, landfill gas, and WWTP sludge are all inadequate to consider a large biomass generation project. Other potentially available biomass fuels, including crop residue and forest biomass, could not support economic electricity generation at this time.

\section{Municipal Solid Waste}

MSW is the best option for generating a significant amount of electricity at Fort Polk's electric rate. Fort Polk's waste, combined with waste from Timberlane Landfill, Sabine Parish Landfill, 
and Jefferson Davis Parish Landfill, were evaluated for economic feasibility as WTE projectseach as a combustion or gasification project. Project economics will depend on the availability and price of waste as well as actual plant size, capital costs, and operating costs. The most costeffective analyzed scenarios are presented in Tables B-4 and B-5. They have SIRs ranging from 0.9 to 1.5 , and IRRs ranging from $6.71 \%$ to $12.70 \%$.

Table B-4: Fort Polk WTE Results

\begin{tabular}{|c|c|c|c|c|c|c|}
\hline Waste Source & $\begin{array}{c}\text { Fort Polk } \\
\text { and } \\
\text { Timberlane } \\
\text { Landfill }\end{array}$ & $\begin{array}{l}\text { Fort Polk } \\
\text { and } \\
\text { Timberlane } \\
\text { Landfill }\end{array}$ & $\begin{array}{l}\text { Fort Polk } \\
\text { and Sabine } \\
\text { Parish } \\
\text { Landfill }\end{array}$ & $\begin{array}{l}\text { Fort Polk } \\
\text { and Sabine } \\
\text { Parish } \\
\text { Landfill }\end{array}$ & $\begin{array}{l}\text { Fort Polk } \\
\text { and } \\
\text { Jefferson } \\
\text { Davis Parish } \\
\text { Landfill }\end{array}$ & $\begin{array}{l}\text { Fort Polk } \\
\text { and } \\
\text { Jefferson } \\
\text { Davis Parish } \\
\text { Landfill }\end{array}$ \\
\hline Technology & Combustion & Gasification & Combustion & Gasification & Combustion & Gasification \\
\hline Plant Size & $13.3 \mathrm{MW}$ & $17.6 \mathrm{MW}$ & $9.9 \mathrm{MW}$ & $13.1 \mathrm{MW}$ & $40.7 \mathrm{MW}$ & $53.8 \mathrm{MW}$ \\
\hline Feedstock Amount & $\begin{array}{c}120,932 \\
\text { tons/yr }\end{array}$ & $\begin{array}{c}120,932 \\
\text { tons/yr }\end{array}$ & $\begin{array}{l}89,784 \\
\text { tons/yr }\end{array}$ & $\begin{array}{l}89,784 \\
\text { tons/yr }\end{array}$ & $\begin{array}{c}369,734 \\
\text { tons/yr }\end{array}$ & $\begin{array}{c}369,734 \\
\text { tons/yr }\end{array}$ \\
\hline Total Plant Cost & $\$ 3,455 / \mathrm{kW}$ & $\$ 4,092 / \mathrm{kW}$ & $\$ 3,667 / \mathrm{kW}$ & $\$ 4,343 / \mathrm{kW}$ & $\$ 2,763 / \mathrm{kW}$ & $\$ 3,272 / \mathrm{kW}$ \\
\hline Capital Cost & $\$ 3,322 / \mathrm{kW}$ & $\$ 3,934 / \mathrm{kW}$ & $\$ 3,526 / \mathrm{kW}$ & $\$ 4,176 / \mathrm{kW}$ & $\$ 2,656 / \mathrm{kW}$ & $\$ 3,146 / \mathrm{kW}$ \\
\hline Sales Tax & $\$ 132.90 / \mathrm{kW}$ & $\$ 157.40 / \mathrm{kW}$ & $\$ 141.00 / \mathrm{kW}$ & $\$ 167.00 / \mathrm{kW}$ & $\$ 106.30 / \mathrm{kW}$ & $\$ 125.90 / \mathrm{kW}$ \\
\hline Fixed O\&M Cost & $\$ 108.5 / \mathrm{kW}$ & $\$ 122.7 / \mathrm{kW}$ & $\$ 119.9 / \mathrm{kW}$ & $\$ 152.6 / \mathrm{kW}$ & $\$ 86.40 / \mathrm{kW}$ & $\$ 56.60 / \mathrm{kW}$ \\
\hline Variable O\&M Cost & $-0.5 \$ / k W h$ & $-0.7 థ / k W h$ & $-0.5 \$ / k W h$ & $-0.7 \$ / k W h$ & $-0.0 \$ / k W h$ & $-0.3 \$ / k W h$ \\
\hline $\begin{array}{l}\text { Feedstock } \\
\text { Cost }\end{array}$ & $-\$ 14.32 /$ ton & $-\$ 14.32 /$ ton & $-\$ 14.48 /$ ton & $-\$ 14.48 /$ ton & $-\$ 10.29 /$ ton & $-\$ 10.29 /$ ton \\
\hline SIR & 1.5 & 1.3 & 1.4 & 1.1 & 1.8 & 1.8 \\
\hline Simple Payback & 9.3 years & 11.1 years & 10.1 years & 12.6 years & 7.7 years & 8.1 years \\
\hline IRR, No Financing & $11.63 \%$ & $9.42 \%$ & $10.58 \%$ & $8.03 \%$ & $14.48 \%$ & $13.38 \%$ \\
\hline
\end{tabular}

These scenarios illustrate economically feasible options available to Fort Polk based on preliminary resource assessments. The assumptions used for waste availability (size of the plant) and the baseline cost metrics are critical to the economic results. If there are any changes to these assumptions, some options may become less attractive or possibly eliminated from consideration. There are economic options, however, and an MSW WTE plant should be pursued.

\section{MSW Waste-to-Energy: Next steps}

Using site and regional MSW to generate electricity appears to be a viable option for Fort Polk and should be pursued. The following steps must occur to implement a WTE project.

- Gain support from stakeholders at Fort Polk. Meet with all interested parties, including Entergy Louisiana LLC, assign roles and responsibilities, and set a path forward.

- Quantify the amount of MSW that is actually available for use in a WTE facility and verify what tipping fee(s) will accompany the waste.

- Consider other feedstock sources if necessary, including family housing MSW, sitegenerated C\&D, and additional C\&D resources from Shammerhorn C\&D Waste. 
- Perform legal and regulatory reviews, including an investigation of the issues involved with routine feedstock delivery to Fort Polk.

- Determine potential locations for a WTE facility. A site is needed that is large enough for the conversion equipment, feedstock preparation, and access; has water and other utilities available; can be accessed by trucks for feedstock delivery; and can be connected to the electric grid. There is available space for a plant, but consideration will have to be made for access due to adjacent National Forest Service land and the associated logging traffic for this area. Additionally, the plant location will need to be at a location where it does not impact Fort Polk training practices.

- Interview developers to assess their potential interest in developing this WTE project. Investigate sources of financing. Once the development interest is secured, plans can proceed with the design and final economic calculations.

\section{Biomass and Waste-to-Energy Sources of Information}

Aabakken J. 2006. Power Technologies Energy Data Book. National Renewable Energy Laboratory. Fourth Edition. NREL/TP-620-39728.

Bain, RL, WA Amos, M Downing, RL Perlack. 2003. Biopower Technical Assessment: State of the Industry and Technology. National Renewable Energy Laboratory. NREL/TP-510-33123.

De La Torre Ugarte, DG, ME Walsh, H Shapouri, SP Slinsky. 2000. The Economic Impacts of Bioenergy Crop Production on U.S. Agriculture. University of Tennessee Agricultural Policy Analysis Center.

EvTEC - Environmental Technology Evaluation Center. 2002. "Environmental Technology Verification Report for the Plasma Enhanced Melter." Civil Engineering Research Foundation.

Fitzgerald, Tim. 2010. Fort Polk Solid Waste Management. Personal communications. February 2010.

Forest Service. 2009. "Forest Inventory \& Analysis Mapmaker Program on Timber Products Output Studies." United States Department of Agriculture. Accessed October 2009 at http://www.fia.fs.fed.us/program-features/tpo/ (last updated October 26, 2009).

Gallagher, P, M Dikeman, J Fritz, E Wailes, W Gauther, and H Shapouri. 2003. Biomass from Crop Residues: Cost and Supply Estimates. United States Department of Agriculture, Office of the Chief Economist. February 2003. Accessed June 2010 at http://www.usda.gov/oce/reports/energy/AER819.pdf.

Gibson, Steve. 2010. Fort Polk Solid Waste Management. Personal communications. February 2010 .

Haq, Zia. 2002. Biomass for Electricity Generation. Energy Information Administration. Accessed February 2010 at http://www.eia.doe.gov/oiaf/analysispaper/biomass/. 
IEA Energy Technology Essentials. 2007. Biomass for Power Generation and CHP. Accessed February 2010 at http://www.iea.org/textbase/techno/essentials3.pdf.

Joiner, John. 2010. Fort Polk Lead Engineer. Personal communications. February 2010.

LDEQ - Louisiana Department of Environmental Quality. 2009. 2009 Solid Waste Capacity Report. Accessed February 2010 at http://www.deq.state.la.us/portal/portals/0/news/pdf/2009SolidWasteCapacityReport.pdf.

LDEQ - Louisiana Department of Environmental Quality. 2007. 2007 Solid Waste Generation and Capacity Report. Accessed February 2010 at http://www.deq.state.la.us/portal/portals/0/news/pdf/2007SolidWasteGenerationandCapacityRep ort.pdf.

NASS - National Agricultural Statistics Service. 2009. “Quick Stats.” United States Department of Agriculture. Accessed October 2009 at http://www.nass.usda.gov/Data_and_Statistics/Quick_Stats/.

O’Dell, Devan. 2010. Fort Polk Engineering Intern. Personal communications. February 2010. Martin, Bruce. 2010. Fort Polk Post Forester. Personal communications. February 2010.

Rainey, Richard. 2009. "Jefferson Parish landfill closure talks OK'd." New Orleans Local News. Accessed February 2010 at http://www.nola.com/news/index.ssf/2009/01/jefferson_parish_landfill_clos.html.

Smith, Ellis. 2010. Fort Polk Director of Public Works. Personal communications. February 2010.

Stagg, Charles. 2010. Fort Polk Environmental Director. Personal communications. February 2010 . 


\section{APPENDIX C}

\section{Analysis of Geothermal Plant Opportunities}




\section{Appendix C: Analysis of Geothermal Power Plant Opportunities}

\section{Geothermal Power Plant Technology}

Geothermal power plants use steam from hot water reservoirs found deep below the Earth's surface. The steam rotates a turbine that activates a generator, producing electricity. There are three commercial types of geothermal power plants used to generate electricity (dry steam, flash steam, and binary cycle), and several newer technologies are entering the marketplace (hot dry rock and engineered geothermal systems). The type of plant depends on the state of the fluid (whether it is steam, hot water, or mixed) and its temperature.

- Dry Steam power plants use underground steam piped directly from wells to the power plant, where it passes through separators to remove small particles before it is directed into a turbine/generator unit. There are only two known underground resources of steam in the United States: The Geysers in northern California and Yellowstone National Park in Wyoming. The only dry steam plants in the country are at The Geysers.

- Flash Steam power plants use geothermal resources that produce high-temperature hot water or a combination of steam and hot water. This very hot water (reservoirs greater than $360^{\circ} \mathrm{F}$ or $182^{\circ} \mathrm{C}$ ) flows up through wells in the ground under its own pressure. As it flows upward and the pressure decreases, some of the hot water boils (flashes) into steam. The steam is then separated from the water and used to power a turbine/generator. Leftover water and condensed steam are injected back into the reservoir, making this a sustainable resource. Depending on the temperature resource, it may be possible to use a second flash tank, where more steam at a lower pressure is separated for generation (double flash plant).

- Binary Cycle power plants utilize a second fluid in a closed cycle to operate the turbine, instead of direct geothermal steam. These plants operate on water at lower temperatures of about $225^{\circ}$ to $360^{\circ} \mathrm{F}\left(107^{\circ}\right.$ to $\left.182^{\circ} \mathrm{C}\right)$. The heat from the hot water is used to boil a working fluid, usually an organic compound with a low boiling point. The working fluid is vaporized in a heat exchanger and used to turn a turbine. The water is then injected back into the ground to be reheated. The water and the working fluid are kept separated during the whole process, so there is minor or no contamination. The advantage of the binary cycle plant is that it can operate with lower temperature water by using working fluids that have an even lower boiling point than water. Binary power plants are available in smaller scales such as 200 to $1,000 \mathrm{~kW}$.

- Hot Dry Rock (HDR) geothermal production utilizes high-temperature rocks found deep (several kilometers) below the surface by pumping high-pressure water down a borehole into a heat zone. The water captures the heat of the rock by traveling through fractures until it is forced out a second borehole and used to generate electricity. Once the water has cooled, it is pumped back underground to heat up again. This process is most easily used in locations with natural geothermal systems with existing cracks or pore spaces.

- Engineered or Enhanced Geothermal Systems (EGS) are similar to HDR systems. In locations where there are few cracks and connected pore spaces, or little to no cracks or 
connectivity, cracks can be created or enhanced. The advantage of HDR or EGS is that geothermal resources can be captured for production in non-tectonically active regions. This technology is still very new and expensive.

\section{Geothermal Energy Analysis Approach}

In the 2005 DoD Renewable Energy Assessment, the Navy's Geothermal Office was responsible for the DoD geothermal power assessment. That task was subcontracted to Innovative Technical Solutions, Inc. (ITSI). The Navy and ITSI ranked installations based on their assessment of potential. The utility grade geothermal assessment included 18 installations identified by DoD. Of those installations, five sites were found to have high potential for utility-grade systems. Fort Polk was not found to be one of five sites with high potential for the occurrence of utility-grade geothermal systems. Fort Polk was determined to be among the 23 sites that have potential for direct-use applications (ITSI 2003).

Funding limited the number of sites that could be inspected and assessed. ITSI visited some locations and collected information through site inspections (for things like hot springs), field measurements, and review of temperature readings from water well drilling logs. This information was compiled in site reports and used to recommend further analysis, typically the drilling of test wells to measure temperature and assess subsurface conditions. Drilling test wells is the next in a progression of steps and is generally very expensive, on the order of $\$ 1$ million per well.

This analysis used the information available from the DoD study, in addition to other readily available sources, to determine if the following conditions exist. These conditions demonstrate utility-grade geothermal potential:

- Existing power plant operation or developer activity

- One or more wells tested with temperatures in excess of $212^{\circ} \mathrm{F}\left(100^{\circ} \mathrm{C}\right)$ logged downhole (at depths less than 3,000 m)

- Demonstrated high fluid flow rates on the order of 1,000 gallons per minute (gpm) per MW

- Heat flow rates greater than $80 \mathrm{~mW} / \mathrm{m}^{2}$ (milliWatts per square meter)

- Other exploration data and information available $\left(\geq 212^{\circ} \mathrm{F}\left[100^{\circ} \mathrm{C}\right]\right.$ not proven).

Since the 2005 DoD geothermal assessment, additional research and development has been done on other geothermal development techniques that may be applicable to additional installations. This new information is interpreted for economic applicability.

\section{Geothermal Resource Characterization}

Geothermal resources include hot springs, geysers, and underground resources of pressurized water and steam accessible via wells, as well as dry steam, hot water, hot dry rocks, and lowtemperature geothermal heat. A known geothermal resource area is an area in which the geology, nearby discoveries, competitive interests, or other indicators show that the potential for extracting geothermal steam or associated geothermal resources is sufficient to warrant consideration. 
For commercial use, it is necessary to have a geothermal reservoir capable of providing hydrothermal (hot water and steam) resources with sufficiently high flow rates. Successful geothermal electrical power generation requires fluid flow rates equal to or greater than $1,000 \mathrm{gpm}$ per MW. For example, $1.5 \mathrm{MW}$ of electricity at a reservoir temperature of $300^{\circ} \mathrm{F}$ $\left(149^{\circ} \mathrm{C}\right)$ requires a flow rate of about $1,000 \mathrm{gpm}$ (McKenna 2006).

Geothermal plants operate in regions with high heat flow rates. Heat flow values above $80 \mathrm{~mW} / \mathrm{m}^{2}$ are considered characteristic of a viable geothermal resource. Productive heat flows are generally greater than $150 \mathrm{~mW} / \mathrm{m}^{2}$ (Blackwell et al. 2003). According to the Geothermal Map of the United States (SMU 2004), the heat flow in the Fort Polk region appears to be 50 to $60 \mathrm{~mW} / \mathrm{m}^{2}$, indicating very low potential.

Utility-grade geothermal energy requires temperatures in excess of $212^{\circ} \mathrm{F}\left(100^{\circ} \mathrm{C}\right)$ at depths less than $3 \mathrm{~km}$. From the Geothermal Temperature at Depth Map published by the Idaho National Laboratory, it is observed that the temperature at 4-km depth is about 248 to $266^{\circ} \mathrm{F}$ (120 to $130^{\circ} \mathrm{C}$ ), indicating a marginal geothermal resource (Figure C-1).

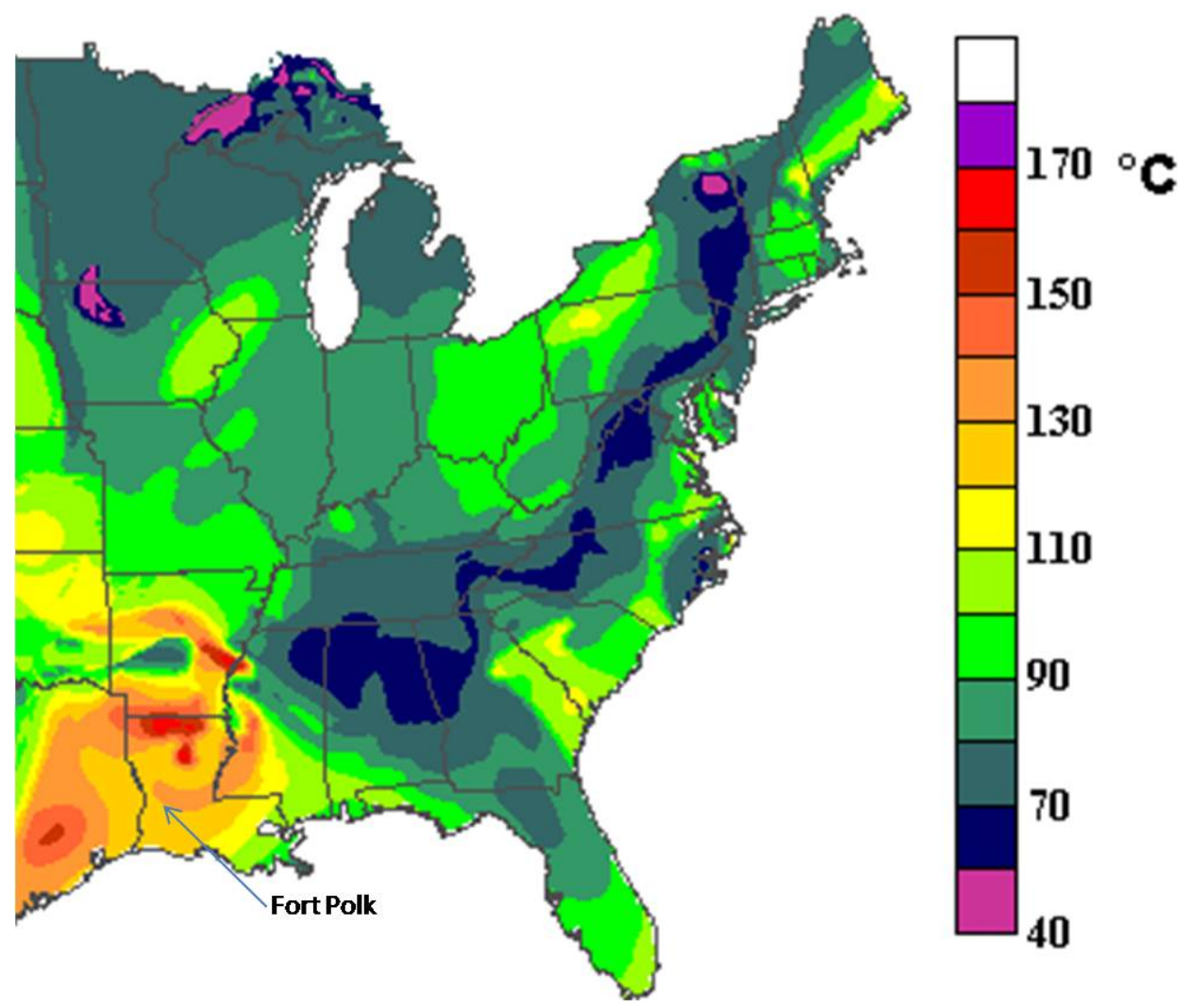

Figure C-1: Estimated temperature at 4 km depth for Eastern United States

Borehole geothermal data for one well (SMIT822) near Fort Polk were obtained. The well is 378 meters deep and has a geothermal gradient of $27^{\circ} \mathrm{C} / \mathrm{km}$ and a heat flow of $53 \mathrm{~mW} / \mathrm{m}^{2}$. These well data confirm the ranges above and result in an estimated temperature of approximately $100^{\circ} \mathrm{C}$ at a depth of $3 \mathrm{~km}$. 


\section{Geothermal Power Plants: Economic and Other Analysis Parameters}

Geothermal power costs are influenced by capital costs for land, drilling, and the physical plant. Capital costs vary over a wide range per installed $\mathrm{kW}$. Capital costs for flash steam plants tend to be less expensive than binary plants. Plant life spans are typically 30 to 45 years.

Capital costs include:

- Initial development work: land leasing, exploration, permitting, test well costs

- Infrastructure: roads, water supply, utilities

- Well field drilling: production wells in addition to already-drilled confirmation wells

- Steam and brine gathering system: pipes and brine separation equipment

- Power plant: physical equipment for energy conversion, including substation

- Interconnection: link of the power plant substation to the transmission corridor

- Soft costs: developers' fees, overhead, financing costs, legal fees, etc.

Geothermal wells are drilled to depths of 200 to 1,500 meters for low- and medium-temperature systems. For high-temperature systems, wells are drilled 700 to 3,000 meters deep. Each well costs $\$ 1$ million to $\$ 4$ million to drill, and a geothermal field may consist of between 10 and 100 wells.

The project cost is also affected by the cost of operation and maintenance (O\&M), the amount of power generated, and the market value of the power. Operating costs range from 0.4 to $2.6 \notin / \mathrm{kWh}$ for conventional geothermal power plants (Shibaki 2003, Hance 2005). Operating plants at over $90 \%$ capacity will result in higher O\&M costs. A larger plant size means lower per-kWh operating costs.

\section{Findings: Geothermal Power Plant Opportunities}

According to existing data, naturally occurring hot water/steam fields and elevated temperatures at economic depths (less than 3,000 m) near Fort Polk show poor potential for economic electricity generation. However, there is potential for alternative geothermal energy production using existing or new gas and oil wells.

The geothermal analysis assumed that electricity transmission lines located on or near a potential Fort Polk geothermal development area would be available to transmit power without substantial additional investment. Economic calculations included in this analysis account for current federal geothermal incentives - a $2.1 \notin / \mathrm{kWh}$ renewable energy production credit and a 5-year accelerated depreciation. The capital cost includes drilling new wells as opposed to using existing wells. The resulting average cost of electricity is much higher than the current rate, making geothermal resources requiring new wells a poor option to pursue at this time.

Table C-1: Geothermal Performance, Cost, and Economic Characteristics

\begin{tabular}{||c|c|c|c|c|c|c||}
\hline $\begin{array}{c}\text { Assumed } \\
\text { Temperature at } \\
\mathbf{3 , 0 0 0} \text { meters }\end{array}$ & $\begin{array}{c}\text { Capacity } \\
\text { Factor }\end{array}$ & $\begin{array}{c}\text { Technology } \\
\text { Type }\end{array}$ & $\begin{array}{c}\text { Project } \\
\text { Size }\end{array}$ & $\begin{array}{c}\text { Estimated } \\
\text { Annual } \\
\text { Production }\end{array}$ & $\begin{array}{c}\text { Average } \\
\text { Cost of } \\
\text { Energy }\end{array}$ & $\begin{array}{c}\text { Total Capital } \\
\text { Cost }\end{array}$ \\
\hline $212^{\circ} \mathrm{F}\left(100^{\circ} \mathrm{C}\right)$ & $96 \%$ & Binary & $5 \mathrm{MW}$ & $43,800 \mathrm{MWh}$ & $17.57 \mathrm{~d} / \mathrm{kWh}$ & $\$ 11,023 / \mathrm{kW}$ \\
\hline
\end{tabular}


During PNNL's visit to Fort Polk, site personnel mentioned they had been in contact with the Vicksburg office of the Army Corps of Engineers about the possibility of using existing oil and gas wells for geothermal power production (known as geopressured-geothermal). The capital costs associated with modifying these wells will be site- and region-specific, will need to include costs to address environmental concerns, and will depend on the type of well used and the quality of the resource.

Fort Polk has two such gas wells inside the fence, but both are on Pearson Ridge and nearly inaccessible. There are, however, several wells within 4 to 5 miles of the post on Forest Service land. It may be possible to use these as part of a closed-loop binary geopressured-geothermal power plant if the quality of the resource is determined to be adequate, if environmental concerns are addressed, and if the capital costs are low enough to make the cost of electricity competitive.

Since PNNL's site visit, meetings have been held between Fort Polk personnel, Vicksburg Army Corps of Engineers, and representatives of Hilcorp Energy Company. The presentation by the Corps of Engineers indicates that DOE has allocated \$43 million in FY 2011 to spend on geopressured-geothermal development. In addition, DoD has interest and possible funding to invest in geopressured-geothermal energy. The Corps of Engineers estimates that there would be zero to minimal cost to Fort Polk for both a feasibility study and the possible follow-on work (Broadfoot et al. 2010).

Hilcorp Energy Company, the fourth-largest privately held oil and natural gas producer in the United States, is requesting permission to explore the geopressured-geothermal potential on Fort Polk and proposes to justify the costs of drilling wells by also exploring for oil and natural gas (Beckett 2010). Their findings align with the findings in this analysis and indicate that developing new wells solely for the purpose of geothermal power generation is not economic. An economic project requires additional resource harvesting to offset the costs of exploring the geopressure zones in the area.

Analysis of geopressured-geothermal resources falls out of the scope of this assessment, but it could provide a path to economic geothermal power production. It is recommended that Fort Polk work with DOE and DoD to further investigate the potential for geopressured-geothermal energy generation on and near the installation, but Fort Polk should not further consider drilling for standard geothermal electricity production at this time.

\section{Geothermal Power Plants: Next Steps}

It is not recommended to take further steps toward developing a geothermal power generation project at this time. To verify if geopressured-geothermal potential exists at Fort Polk, the following steps are recommended.

- Confirm the availability of proposed DOE and DoD funding and when it is expected to be distributed.

- Discuss the impact and responsibilities geopressured-geothermal exploration would place on Fort Polk.

- Gain support from stakeholders at Fort Polk and meet with all parties of interest to assign roles and responsibilities and set a path forward. 


\section{Geothermal Power Plant Sources of Information}

Beckett A. 2010. "Developing Geothermal Power at Fort Polk, LA." Presentation at Fort Polk by Hilcorp Energy Company. March 30, 2010.

Blackwell D, K Wisian, M Richards, M Leidig, R Smith, and J McKenna. 2003. Geothermal Resource Analysis and Structure of Basin and Range Systems, Especially Dixie Valley Geothermal Field, Nevada. Southern Methodist University Department of Geological Sciences. Dallas, Texas. June 2003. Accessed at http://www.osti.gov/energycitations/servlets/purl/813485-smnwbs/native/813485.PDF.

Brasz JJ, BP Biederman, and G Holdmann. 2005. "Power Production from a Moderate Temperature Geothermal Resource.” Geothermal Resources Council Annual Meeting, September 25-28, 2005, Reno, Nevada. Accessed May 2010 at http://www.yourownpower.com/Power/grc\%20paper.pdf.

Broadfoot S, A Beckett, and B Russo. 2010. "Geothermal at Fort Polk." Presentation at Fort Polk by U.S. Army Engineer Research and Development Center, Central Louisiana Electric Company, and Hilcorp Energy Company. March 30, 2010.

Campbell RG and MM Hatter. 1991. "Design and operation of a geopressured geothermal hybrid cycle power plant." Vol. I, 180 p. and Vol. II, 172 p. Eaton Operating Company, Inc., Cleveland, Ohio.

GeothermEx, Inc. 2004. "New Geothermal Site Identification and Qualification.” California Energy Commission. Public Interest Energy Research Report. April 2004. Accessed at http://www.geothermex.com/CEC-

PIER_Report_New_Geothermal_Site_Identification_and_Qualification.pdf.

Hance CN. 2005. "Factors Affecting Costs of Geothermal Power Development." Geothermal Energy Association, Washington D.C. August 2005. Accessed at http://www.geoenergy.org/publications/reports/Factors \%20Affecting $\% 20$ Cost $\% 20$ of $\% 20$ Geothermal $\% 20$ Power \%20Development $\% 20-\% 20$ August $\% 202005$.pdf.

INL - Idaho National Laboratory. 2005. Temperature at Depth Maps for the Continental United States. "Estimated Temperature at 3 Kilometers." Idaho Falls, Idaho. April 2005. Accessed at http://geothermal.id.doe.gov/maps/.

ITSI - Innovative Technical Solutions. 2003. "Geothermal Energy Resource Assessment on Military Lands." Prepared for NAWS China Lake. October 2003. Accessed at http://www.geothermal.org/GEO 0001.PDF.

McKenna JR. 2006. "Increasing Electrical Power Capacity for Military Applications." U.S. Army Corps of Engineers Engineer Research \& Development Center. Accessed at http://www.smu.edu/geothermal/Oil\&Gas/Mckenna_Army\%20Corps.pdf.

MIT-led Interdisciplinary Panel. 2006. "The Future of Geothermal Energy: Impact of Enhanced Geothermal Systems (EGS) on the United States in the 21st Century." U.S. Department of 
Energy. Washington, DC. Accessed at http://geothermal.inl.gov/publications/future_of_geothermal_energy.pdf.

Petty S. 2007. "Engineering Geothermal Systems in Oil and Gas Reservoirs." Presentation at the Southern Methodist University (SMU) Geothermal Lab conference on Geothermal Energy Utilization Associated with Oil and Gas Development. June 12 and 13, 2007, Dallas Texas. Accessed at http://www.smu.edu/geothermal/Oil\&Gas/2007/Petty_Susan\%20Engineering\%20Geothermal\%2 0Systems\%20in\%20Reservoirs.pdf.

Rafferty K. 2000. "Geothermal Power Generation: A Primer on Low-temperature, Small-scale Applications." Geo-Heat Center. January 2000. Accessed at http://geoheat.oit.edu/pdf/powergen.pdf.

Shibaki M. 2003. "Geothermal Energy for Electric Power.” A Renewable Energy Policy Project (REPP) Issue Brief. December 2003. Accessed at http://www.crest.org/articles/static/1/binaries/Geothermal_Issue_Brief.pdf.

SMU - Southern Methodist University Geothermal Lab. 2004. "Geothermal Map of the United States (heat flow map)." Dallas, Texas. 2004. Accessed at http://www.smu.edu/geothermal/heatflow/geothermal_all_us_clipped_150dpi_pagesize_legend.g if.

Williams CF, M Reed, and R Mariner. 2008. "A Review of Methods Applied by the U.S. Geological Survey in the Assessment of Identified Geothermal Resources." U.S. Geological Survey. Open-File Report 2008-1296. 


\section{APPENDIX D}

\section{Analysis of Ground Source Heat Pump Opportunities}




\section{Appendix D: Analysis of Ground Source Heat Pump Opportunities}

\section{Ground Source Heat Pump Technology}

Ground source heat pumps (GSHPs) use the stable temperatures of the earth and groundwater to improve the coefficient of performance of heating and cooling applications for buildings. Common GSHP configurations include open-loop, horizontal closed-loop, and vertical closedloop.

$\checkmark$ Open-loop systems use open wells or bodies of water as direct heat transfer mediums to provide cool temperatures in the summer and warm temperatures in the winter. Heat transfer is only needed once, at the building, because groundwater is used directly, and the limited drilling and trenching results in a lower first cost. It should be noted that there is concern about the permitting process for open-loop systems.

$\checkmark$ Closed-loop systems use heat transfer fluid inside a sealed pipe to exchange heat with the earth. Closed-loop systems have lower pumping requirements and are more efficient than open-loop systems. However, soil type and moisture content are more critical to the performance of these systems, and the trenching and drilling significantly increases first cost. Horizontal loops require trenching so that all the piping lies at the same depth in the ground.

$\checkmark$ Vertical closed-loop GSHPs are deployed in vertical boreholes and are the most efficient configuration.

GSHPs are applicable in almost any building with both heating and cooling. They can be used in buildings as small as 100 square feet, or up to 1 million square feet. Multiple GSHPs can be used in a single building to meet the load, or the same ground loop can be shared between buildings.

To install GSHPs at a building, the surrounding area will have certain prerequisites, depending on the type of GSHP. Open-loop GSHPs need a water source and sink. The source can be a well or open body of water. To discharge this water, the sink can be a secondary well, the open body of water used as the source, another body of water, or a storm drain. Water volume requirements depend on the size of GSHP installed, but typically between 1.5 and 3.0 gallons per minute are needed per cooling ton. This greatly affects the feasibility of open-loop systems in some areas, as do local codes and regulations. Many locations do not want to risk groundwater depletion or contamination.

Horizontal closed-loop GSHPs have a different limiting factor: sufficient land area. The heat transfer for these systems occurs in pipes laid in trenches that are between 100 and 400 feet long per cooling ton, spaced between 6 and 12 feet apart. The soil characteristics and number of pipes per trench determine the pipe length; more pipes (up to six) per trench save land space but require more piping.

Where significant land area or water volumes are not available, vertical closed-loop GSHPs may be the only option. In these systems, the heat transfer pipes are placed vertically in the ground at 
depths of between 75 and 300 feet. Some land area is still required because the pipe wells need to be spaced at least 15 to 20 feet apart, and 200 to 600 feet of piping are needed per cooling ton.

\section{Ground Source Heat Pump Analysis Approach}

For the purposes of this assessment, GSHPs were evaluated using the data from the 2006 Facility Energy Decision System (FEDS) assessment for Fort Polk. Preliminary analyses of open-loop, horizontal closed-loop, and vertical closed-loop configurations were performed for all buildings included in the FEDS assessment.

The FEDS building energy model (see Appendix A) was used to develop a representation of Fort Polk based upon a PNNL data-gathering trip in 2006. All existing buildings at that time were included in the model, and this renewables analysis used the model to assess the current costeffective potential for GSHP retrofits in each of those buildings. Buildings built since 2006 were not added to the model because buildings that new are typically not cost-effective to retrofit, and the types and sizes of the new buildings are still represented. Based on these results, site judgment can be used to determine cost-effectiveness of retrofitting the newer buildings in the future.

Building data were entered for groups of similar buildings based on age, size, and use type (see Table D-1). The FEDS model was updated with current fuel, equipment, and labor prices as well as fuel use information. 
Table D-1: Building Groups Analyzed in FEDS for GSHPs

\begin{tabular}{|c|c|c|c|c|c|}
\hline \multirow[b]{2}{*}{$\begin{array}{c}\text { Group } \\
\text { ID }\end{array}$} & \multicolumn{4}{|c|}{ Building Group Description } & \multirow[b]{2}{*}{$\begin{array}{l}\text { Example } \\
\text { Building }\end{array}$} \\
\hline & Use Type & $\begin{array}{l}\text { Average } \\
\text { Size (sf) }\end{array}$ & $\begin{array}{l}\text { Average } \\
\text { Vintage }\end{array}$ & $\begin{array}{c}\text { Number of } \\
\text { Buildings } \\
\text { Represented }\end{array}$ & \\
\hline $10 a$ & 1940s Administration & 3,897 & 1941 & 1116 & 2543 \\
\hline $10 b$ & Small Older Administration & 2,712 & 1979 & 66 & 1651 \\
\hline $10 c$ & Small Newer Administration & 3,356 & 2000 & 43 & 7305 \\
\hline $10 d$ & Medium Administration & 14,028 & 1980 & 16 & 1072 \\
\hline $10 e$ & Large Administration & 24,258 & 1981 & 25 & 1830 \\
\hline $10 f$ & Very Large Administration & 68,984 & 1994 & 3 & 350 \\
\hline $\log$ & 9600 SF Administration & 9,600 & 1999 & 16 & 8205 \\
\hline $21 a$ & Clinics & 10,719 & 1980 & 8 & 3504 \\
\hline $21 b-1$ & Hospital (Floors 1-2) & 160,209 & 1983 & 1 & 285 \\
\hline $21 b-2$ & Hospital (Floors 3-7) & 207,585 & 1983 & 1 & 285 \\
\hline 23 & Electronics & 5,611 & 1973 & 28 & 4420 \\
\hline $30 a$ & Newer Barracks & 9,600 & 2002 & 8 & 8435 \\
\hline $30 b$ & Guest Lodging & 16,817 & 1981 & 4 & 332 \\
\hline $30 c$ & 1940s Barracks & 5,140 & 1942 & 112 & 8018 \\
\hline $30 d$ & 1970-80s Medium Barracks & 31,370 & 1979 & 19 & 1150 \\
\hline $30 \mathrm{e}$ & 1970-80s Large Barracks & 44,388 & 1978 & 15 & 1152 \\
\hline $40 a$ & Older Small Storage & 1,799 & 1953 & 77 & 4050 \\
\hline $40 b$ & Mid-Aged Small Storage & 1,465 & 1988 & 190 & 4128 \\
\hline $40 c$ & Newer Storage & 6,407 & 1998 & 59 & 3218 \\
\hline $40 d$ & Large Storage & 22,255 & 1996 & 2 & \\
\hline $50 a$ & Small Maintenance Facilities & 1,987 & 1969 & 161 & 3830 \\
\hline $50 b$ & Medium Maintenance Facilities & 21,574 & 1983 & 25 & 2751 \\
\hline $50 c$ & Large Maintenance Facilities & 62,505 & 1989 & 3 & 4386 \\
\hline $50 d$ & Hangars & 20,197 & 1986 & 6 & 4297 \\
\hline $60 a-1$ & Commissary & 82,431 & 1976 & 1 & 830 \\
\hline $60 a-2$ & Post Exchange & 70,832 & 1979 & 1 & 840 \\
\hline $60 \mathrm{~b}$ & Security \& Exchange Facility & 6,322 & 1978 & 17 & 1455 \\
\hline $60 c-1$ & 1942 Dining Halls & 2,733 & 1942 & 21 & 7180 \\
\hline $60 c-2$ & Medium Dining Halls & 6,667 & 1993 & 8 & 8009 \\
\hline $60 c-3$ & Large Dining Halls & 16,093 & 1979 & 3 & 1162 \\
\hline $80 b$ & Miscellaneous & 7,189 & 1973 & 52 & 427 \\
\hline
\end{tabular}

Site-specific typical meteorological year (TMY) weather data and soil/ground characteristics were also used in the analysis. The weather data used for this analysis came from Fort Polk, and the following soil characteristic values were used in the calculations: 
- Soil thermal diffusivity: $0.035 \mathrm{sf} / \mathrm{hr}$

- Overburden depth: $100 \mathrm{ft}$

- Bedrock thermal conductivity: $1.4 \mathrm{Btu} /\left(\mathrm{hr} \cdot \mathrm{ft} \cdot{ }^{\circ} \mathrm{F}\right)$.

These values correspond to the values of heavy saturated soil. They were also used during the analysis of the large-scale GSHP project in the mid-1990s (see Findings section below).

However, actual testing is still necessary to evaluate the soil characteristics of specific sites before actual project costs and returns can be determined. The model does not consider site limitations like land area or water source availability (for closed and open loops, respectively). The assumption is that there are sufficient thermal sources/sinks in place.

\section{Ground Source Heat Pump Resource Characterization}

GSHP assessments using FEDS have been completed at many sites in the past using the same analytic approach. In general, conditions favoring replacement of existing heating and cooling systems with GSHPs include:

$\checkmark$ Replacing old equipment. Equipment at the end of its useful life that will soon be replaced provides further economic incentive for GSHP installations, particularly if existing ductwork can be reused.

$\checkmark$ More extreme climates. Cold winters, hot summers, or large daily temperature swings allow GSHPs to operate more efficiently than other electric cooling and heating systems. The cost of heating operation is comparable to non-electric heating systems.

$\checkmark$ High cost of non-electric fuels. If electricity is less than approximately 3.5 times as expensive than other fuels, GSHPs will generally be cost-effective. If no other fuel option is available and electric costs are high, GSHPs will be less expensive to operate than air-source heat pumps.

GSHPs are often not cost-effective in a building that:

$\checkmark$ Does not have both cooling and heating. A building needs to be heated and cooled to take advantage of the GSHP efficiency in both modes. However, most of the savings are realized in the heating mode, so buildings with no cooling can still benefit from GSHPs.

$\checkmark$ Does not currently have ductwork. Installing a new air distribution system in addition to the conditioning equipment generally adds too much cost for a GSHP retrofit, unless the building is modified to allow zone level heat pumps to be used in conjunction with a water loop connecting the terminal units to a shared ground loop.

$\checkmark$ Is newer. Newer buildings (less than about 4 years old) generally have fairly efficient equipment (or at least the performance has not yet degraded significantly). As a result, premature replacement with a GSHP is generally uneconomic. In addition, the building envelope tends to be better, lengthening payback duration. 
$\checkmark$ Is located in a mild climate. An air-source heat pump has many of the benefits of a GSHP, except in extreme temperature conditions. Moderate temperature conditions are often not sufficient to justify replacement of air-source heat pumps.

$\checkmark$ Is connected to a central energy plant (unless the CEP will be abandoned). Although central energy systems are often considered to be large energy wasters, on a building-bybuilding basis (which does not account for distribution losses), it is difficult to justify replacement. Centralized chiller plants can use larger, more efficient water-cooled units and can stage several chillers to run closer to full load (which is the most efficient mode).

\section{Ground Source Heat Pumps: Economic and Other Analysis Parameters}

FEDS allows two primary financing options: appropriated funding (using Energy Conservation Investment Program, ECIP, funds) and alternative financing (Utility Energy Services Contract (UESC) or Energy Saving Performance Contract (ESPC)). The parameters for alternative financing can be adjusted to match the options available to the site. For this assessment, a project life of 25 years and a third-party interest rate of $5 \%$ were used.

FEDS uses the site electric rate schedule and energy costs to determine fuel costs and savings for GSHP retrofits. The entire rate schedule is entered into the modeling software so that consumption and demand can be calculated on a time-of-use basis. At Fort Polk, there are two main service locations; Fort Polk South and Fort Polk North. Electric rates vary slightly between the two meters and between winter and summer. GSHPs were analyzed with both North Fort and South Fort rate schedules. Electricity is charged on a block schedule with no demand charges, but only the marginal rate is needed in the model to calculate retrofit savings. The marginal rates, or the last tier of the block rate schedule, are as follows.

Fort Polk South

$\checkmark$ Summer: 6.786 $/ \mathrm{kWh}(\$ 19.88 / \mathrm{MMBtu})$

$\checkmark$ Winter: $6.69 \notin / \mathrm{kWh}(\$ 19.61 / \mathrm{MMBtu})$

Fort Polk North

$\checkmark$ Summer: $6.89 \notin / \mathrm{kWh}(\$ 20.19 / \mathrm{MMBtu})$

$\checkmark$ Winter: $6.846 \notin / \mathrm{kWh}(\$ 20.06 / \mathrm{MMBtu})$

A natural gas price of $\$ 6.08 / \mathrm{MMBtu}$ was used for this analysis. This value is based on both historical data for Fort Polk, obtained from the Army Energy and Water Reporting System (AEWRS), and regional price trends.

\section{Findings: Ground Source Heat Pumps}

At this time, no GSHP retrofit projects were found to be cost-effective for Fort Polk. These findings are driven primarily by the cooling-dominated climate and the low cost of fossil fuel. Most of the savings from a GSHP retrofit are on the heating side, where equipment efficiency increases by a factor of 4 or more. Furthermore, Fort Polk's natural gas prices are low by both historical and regional standards, and GSHPs would mostly be replacing natural gas furnaces for heating. Because the cost of heating is low and the heating season is mild, the overall savings in 
the heating mode are low. On the cooling side, savings are also low. The widespread use of central chilled water generated by large, high-efficiency chillers at Fort Polk makes GSHP projects even less economic because GSHP cooling efficiency cannot compete.

These results contrast with those that led to the large-scale installation of GSHPs in much of Fort Polk's family housing from 1995 thru 1996. There are a number of possible reasons for this discrepancy, the most likely being the different bundling of projects and the characteristics of the buildings in which they were to be installed. The previous installation included other modifications such as lighting and ceiling insulation upgrades. The project also included integrated heat pump domestic hot water heating, from which the majority of the energy savings was obtained (Hughes and Shonder 1998). No other efficiency upgrades were considered in the current analysis. Also, family housing tends to present more economic opportunities for GSHPs because of their (typically) more balanced heating and cooling loads. Family housing was not considered in the current study because of privatization.

\section{Ground Source Heat Pumps: Next Steps}

Because there are no GSHP projects that are currently cost-effective, there are no immediate next steps. However, as fuel prices change or new incentives become available in the future, GSHP projects may become economic. For GSHPs to become cost-effective, fossil fuel prices would need to increase substantially. Alternatively, a decrease in the cost of loop installation and equipment costs would also help these projects.

New construction is also an option; retrofit GSHP installations (what was analyzed here) are more expensive. When a new site is being excavated, test the soil to determine site-specific conductivity and other characteristics. GSHPs should always be considered during new construction design. Fort Polk should also analyze buildings with failed heating and cooling equipment and major renovation projects to determine if opportunities for GSHPs exist.

\section{Ground Source Heat Pump Sources of Information}

Hughes PJ and JA Shonder. 1998. The Evaluation of a 4000-Home Geothermal Heat Pump

Retrofit at Fort Polk, Louisiana: Final Report. ORL/CON-460, Oak Ridge National Laboratory, Oak Ridge, Tennessee. Accessed June 2010 at

http://www.ornl.gov/sci/ees/etsd/btric/pdfs/com fortpolk_ornlrpt.pdf.

Federal Technology Alert. 2001. "Ground Source Heat Pumps Applied to Federal Facilities Second Edition.” Federal Energy Management Program. DOE/EE-0245, Washington D.C. March 2001. Accessed at http://www1.eere.energy.gov/femp/pdfs/FTA_gshp.pdf. 


\section{APPENDIX E}

\section{Analysis of Solar Opportunities}




\section{Appendix E: Analysis of Solar Opportunities}

\section{Solar Technology}

There is a wide range of solar technologies and applications available for energy generation. Solar technologies can be classified by the specific technique used for converting solar energy into useful energy. Solar energy is unique in that the sun's energy, or insolation, can be captured to provide electrical energy, heating energy (solar thermal), or a combination of both.

Solar technologies can be further categorized by their scale. Large-scale solar projects can be massive in scope with hundreds of collectors and an energy output expressed in hundreds of kilowatts. Smaller-scale projects, often at the building level, are also possible and may be more desirable because of land area limitations, aesthetic considerations, or energy security. Certain solar technologies, like photovoltaics (PV), can be either large-scale or small-scale while technologies like solar hot water heaters are only found at the building level.

\section{Solar Electric}

Solar electric collectors are either PV arrays or concentrating solar arrays. There are three major PV array subcategories, as follows:

* Flat Panel. Arrays of PV modules mounted on racks either at ground level or on rooftops at a fixed angle. Generally, this angle is equal to the location's latitude.

Axis-Tracking. PV arrays can be mounted on an assembly that moves throughout the day and keeps the array positioned at an optimum angle to maximize the captured sunlight (Figure E-1). An axis-tracking system can be either single- or dual-axis in nature. A single-axis tracking system typically has a fixed tilt that elevates the panel off the ground and the system follows the sun's trajectory across the sky. These systems are able to collect more sunlight than nontracking systems. A dual-axis tracking system allows the panels to rotate along two axes, which maximizes the panel's ability to harvest solar energy. However, these systems are more complex and impose additional operations and maintenance costs compared to flat panel assemblies.

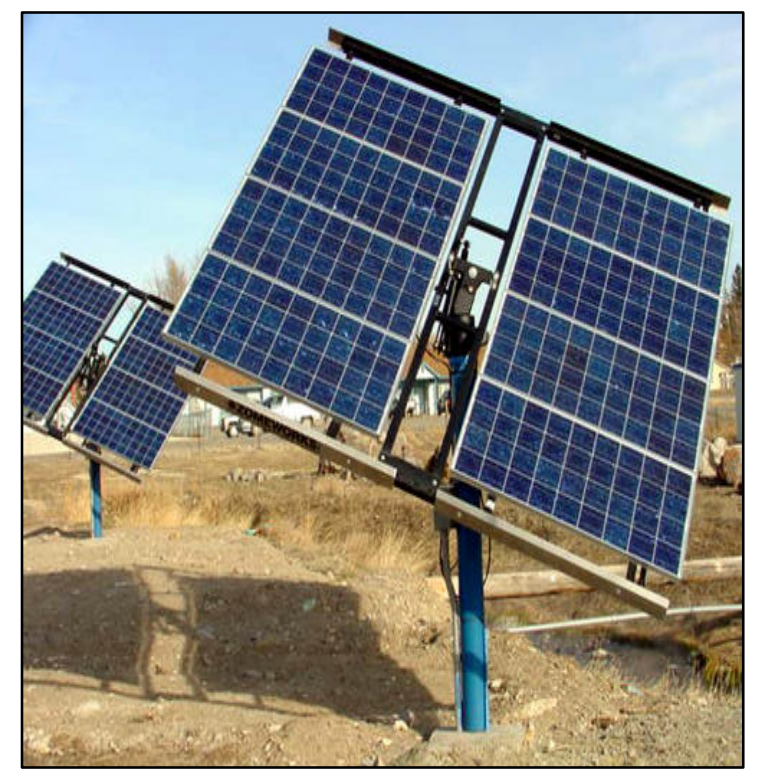

Figure E-1: Dual-Axis Tracking PV Array

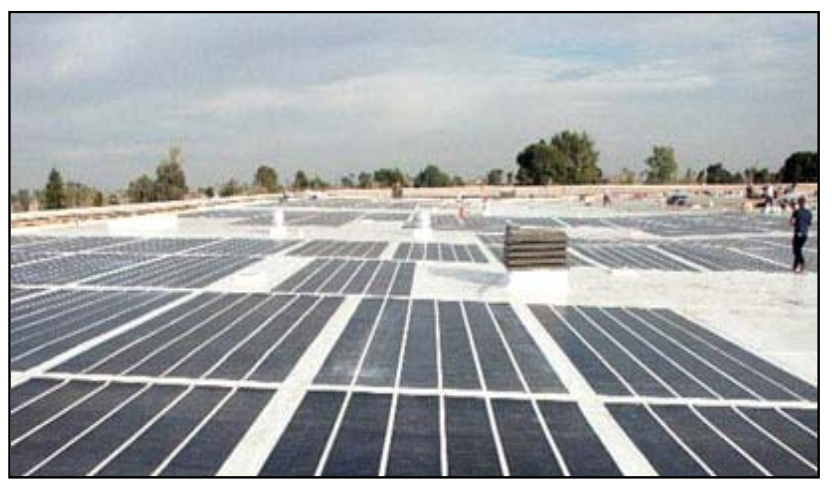

Figure E-2: Integrated PV on Rooftop 
* Integrated PV Panel. PV panels can also be integrated with building roofing material, which can provide a cleaner look than stand-alone panels. Integrated PV panels can come as replacements for standard shingles, metal standing-seam roofing, and membrane roofing for flat roofs (Figure E-2). The lack of tilt usually prevents the system from optimizing its electricity generation. However, the lower capital costs of these systems can make them more cost-effective than other PV systems. One problem with roof-mounted systems is that the panels can be easily obscured by snow or other detritus unless they are regularly cleaned.

Concentrating solar power (CSP) systems use mirrors, lenses, and other optical devices to concentrate the sun's energy onto a receiver. The high temperatures generated by the focused sunlight can then be used for energy production. There are three primary configurations of thermal CSP systems:

* Solar Dish. A solar dish system employs an engine that is able to harvest thermal energy to generate electricity. These dual-axis tracking systems use dish-like concentrators to focus thermal energy on a point where a heat engine is mounted. Stirling engines are frequently used in solar dish applications (Figure E-3). Most systems are several kilowatts to tens of kilowatts in size.

* Solar Power Tower. A solar power tower system uses large arrays of mirrors, or heliostats, to concentrate the sun's energy on a central receiver tower to produce steam that drives a generator. Thermal

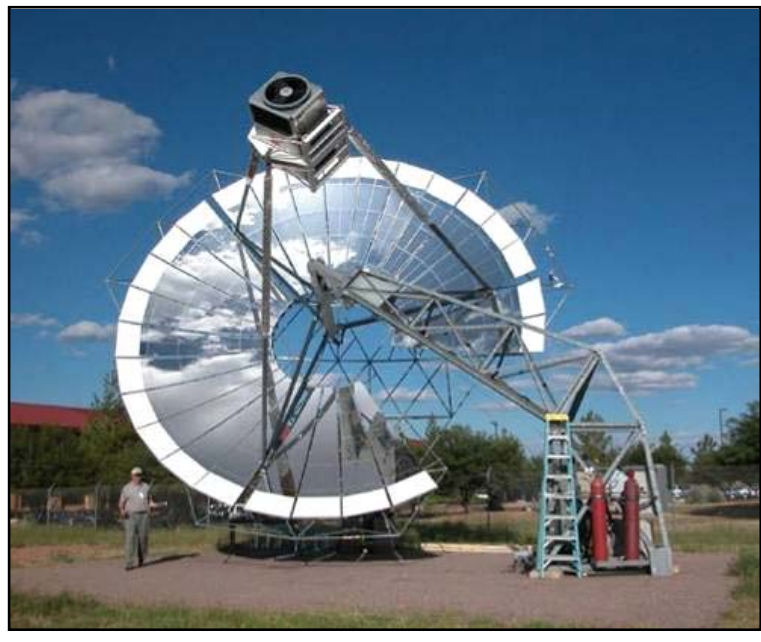

Figure E-3: Fort Huachuca Stirling Engine Solar Dish storage allows the system to store excess thermal energy for use at dusk and into the evening. Most existing or planned commercial solar power tower plants are larger than $10 \mathrm{MW}$.

* Solar Trough. When used for power generation, these large arrays concentrate the sun's energy onto a pipe containing a liquid that is used to generate steam that drives a generator. These systems use single-axis tracking mirrors or reflectors orientated along the north-south axis and are sensitive to the slope of the ground as a result of the need to pump the liquid through the collector tubes. Cogeneration and thermal storage are options for this technology as well. Solar trough plants are typically $40 \mathrm{MW}$ or larger.

Thermal CSP plants are still in various stages of development. Solar trough plants are the most advanced while the solar dish and solar power tower systems are less mature. While thermal CSP plants are somewhat unproven compared to traditional PV plants, they have the potential to deliver large quantities of energy at a cost below that of PV. Thermal concentrating power systems were not considered for this assessment because the available direct normal insolation at Fort Polk is not close to the $6.75 \mathrm{kWh} / \mathrm{m}^{2} /$ day threshold for CSP feasibility. Direct normal insolation is a subset of the total insolation levels that excludes the indirect (diffuse) insolation, which is reflected from clouds or the ground, because this insolation cannot be concentrated. 
Based on data from the National Air and Space Administration's (NASA) Surface Meteorology and Solar Energy (SSE) Database, Fort Polk has an average direct normal insolation level of $4.42 \mathrm{kWh} / \mathrm{m}^{2} /$ day, which is below the $6.75 \mathrm{kWh} / \mathrm{m}^{2} /$ day target.

Lastly, concentrating PV (CPV) is beginning to gain attention as well. In a CPV system, mirrors and/or lens focus sunlight onto a small area of PV material. Typically, this PV material is more sophisticated and costly than the PV material used in most conventional solar cells. However, these advanced PV cells are also more efficient and are capable of absorbing insolation levels equivalent to dozens to hundreds of suns. This technology is promising because it may lead to low cost solar energy as a result of reduced system materials cost. While there are several commercial, small-scale CPV arrays and a handful of medium-scale utility demonstration projects, this technology is still too immature to consider for use at Fort Polk at this time.

\section{Solar Thermal and Daylighting}

Rather than electricity as the end product, solar energy can also be used to directly heat air in the form of transpired solar collectors (i.e., solar walls), water that is used for space heating, or water that is used for service hot water (SHW) or swimming pools. These solar energy systems can be cost-competitive even when PV is not. However, solar thermal projects do not count towards the EPAct mandate and therefore are excluded from this analysis.

Daylighting fixtures are also becoming an increasingly important part of energy management. Modern versions of traditional skylights have better insulating properties and light dispersion. Light shelves, atriums, and solar tubes are other examples of daylighting fixtures. Again, these are solar-based systems that can offset electricity consumption when properly implemented, but they do not generate electricity themselves. Although daylighting retrofits can be economic, daylighting is most cost-effective when implemented during a building's planning phase. Like the above-mentioned solar thermal technologies, daylighting technologies do not count towards the EPAct mandate.

\section{Solar Analysis Approach}

The analytic approach for the solar energy assessment consists of the following steps:

$\checkmark \quad$ Identify solar potential-Use established sources to determine seasonal and annual solar radiation for the site.

$\checkmark \quad$ Determine utility perspective-Obtain electric rate tariff information, evaluate state and local regulations, and identify grants, incentives, and other support.

$\checkmark \quad$ Identify potential development areas-Study existing electrical transmission system and identify installation-specific sites and potential users of generated energy.

$\checkmark \quad$ Determine applicable solar technology-Evaluate solar electric technologies, including both large-scale (approximately $500 \mathrm{~kW}$ to $5+\mathrm{MW}$ ) applications, such as an array of ground-mounted PV panels, and small-scale (30 kW to $500 \mathrm{~kW})$ applications, such as roof-mounted PV systems.

$\checkmark \quad$ Develop project economics-Determine project capital investment requirements and project operations and maintenance costs, and then estimate the economic value of expected electric production based on selected solar technology and market prices. 


\section{Solar Resource Characterization}

Louisiana's average insolation levels are between 5.0 to $5.5 \mathrm{kWh} / \mathrm{m}^{2} /$ day. Fort Polk has a moderate solar resource (Figure E-4, note that this map displays insolation on a latitude-tilted collector and not direct normal insolation).

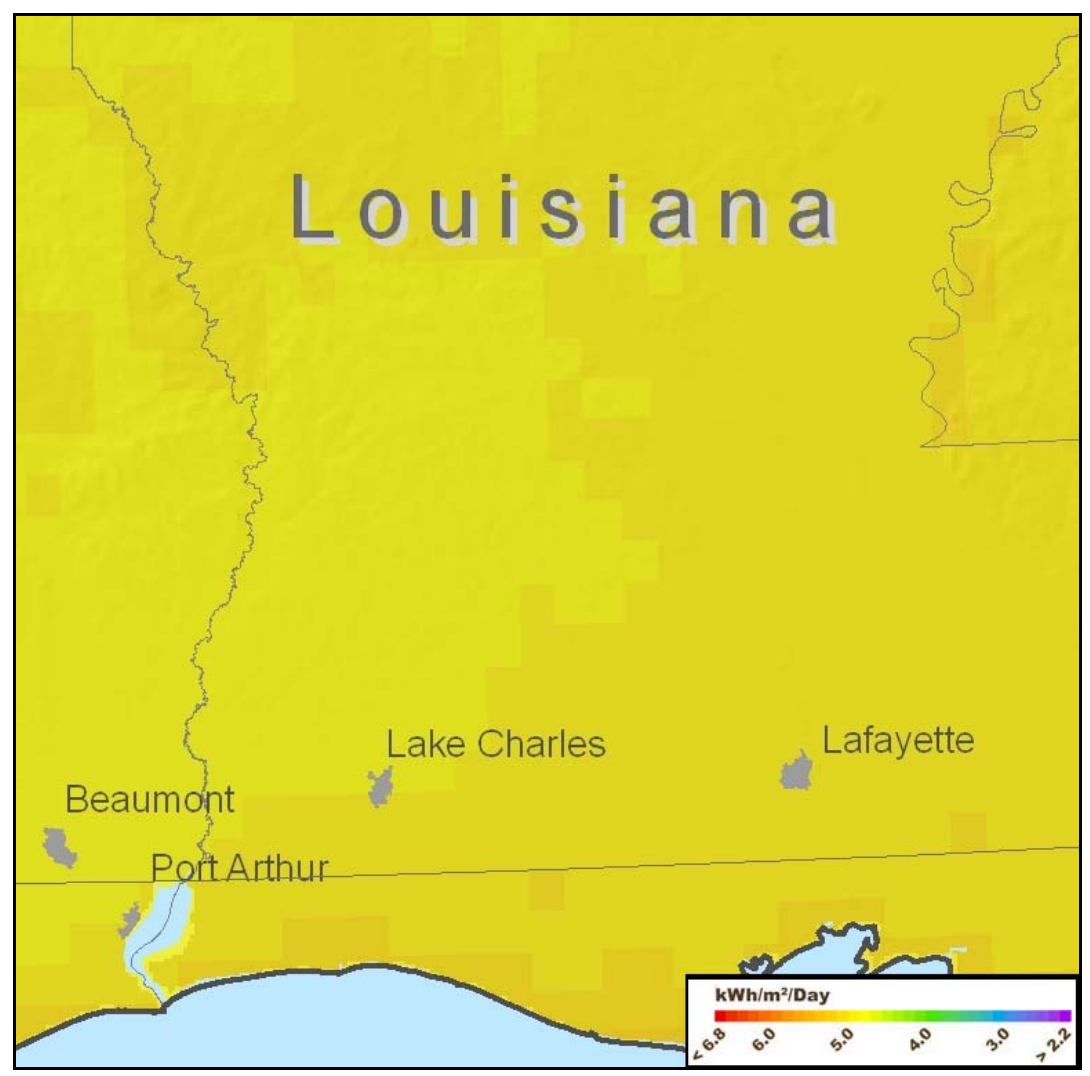

Figure E-4: Solar Insolation Levels, NREL Solar Resource Map

The solar resource potential was estimated using the National Air and Space Administration's (NASA) Surface Meteorology and Solar Energy (SSE) data and Natural Resources Canada's RETScreen analysis software. The SSE data set is a continuous and consistent 10-year global climatology of insolation and meteorology data on a $1^{\circ}$ by $1^{\circ}$ grid system. Although the SSE data within a particular grid cell are not necessarily representative of a particular microclimate or point within the cell, the data are considered to be the average over the entire area of the cell. That estimate should be sufficiently accurate for preliminary feasibility studies of new renewable energy projects. In addition, the SSE database provides year-to-year variability in terms of 10 -year maximums and minimums for a number of parameters.

In Table E-1, the average solar insolation data are shown for several different surface orientations, including a flat roof surface, a flat panel with a tilt equal to the latitude, a dual-axis tracking panel, a flat, wall-mounted panel, and direct normal insolation. Average monthly insolation values are provided in $\mathrm{kWh} / \mathrm{m}^{2} /$ day for the following conditions:

- Tilt $0-$ Collector installed at a $0^{\circ}$ tilt (i.e., on a flat surface such as a roof).

- Tilt (lat-15) - A tilt of latitude minus $15^{\circ}$ would favor energy production in the summer when the sun is higher. 
- Tilt lat-Tilting a PV array at an angle equal to the latitude is a generally accepted way to optimize annual electricity production.

- Tilt (lat+15) - A tilt of latitude plus $15^{\circ}$ would favor energy production in the winter when the sun is lower.

- Tilt 90-Collector installed against a vertical surface (i.e., wall).

- Dual-Axis Tracking - Collector capable of tracking the sun's path over the course of the day, which helps maximize its energy production.

- Direct Normal Insolation - This is the amount of direct insolation that directly strikes a surface that tracks the sun. This parameter is important for concentrating solar power systems.

Table E-1: Monthly Averaged Insolation at Fort Polk (kWh/m²/day)

\begin{tabular}{|l|c|c|c|c|c|c|c|c|c|c|c|c|c||}
\hline \hline & Jan & Feb & Mar & Apr & May & Jun & Jul & Aug & Sep & Oct & Nov & Dec & $\begin{array}{c}\text { Annual } \\
\text { Average }\end{array}$ \\
\hline Tilt 0 & 2.72 & 3.52 & 4.46 & 5.31 & 5.92 & 6.4 & 6.4 & 6.01 & 5.06 & 4.27 & 3.12 & 2.56 & 4.65 \\
\hline Tilt 16 & 3.32 & 4.03 & 4.83 & 5.45 & 5.82 & 6.16 & 6.21 & 6.06 & 5.38 & 4.88 & 3.79 & 3.19 & 4.93 \\
\hline Tilt 31 & 3.71 & 4.30 & 4.94 & 5.30 & 5.46 & 5.68 & 5.77 & 5.81 & 5.40 & 5.20 & 4.22 & 3.62 & 4.95 \\
\hline Tilt 46 & 3.90 & 4.35 & 4.80 & 4.91 & 4.85 & 4.93 & 5.05 & 5.27 & 5.16 & 5.24 & 4.43 & 3.85 & 4.73 \\
\hline Tilt 90 & 3.28 & 3.29 & 3.16 & 2.66 & 2.26 & 2.13 & 2.21 & 2.60 & 3.13 & 3.86 & 3.65 & 3.33 & 2.96 \\
\hline $\begin{array}{l}\text { Dual-Axis } \\
\text { rracking }\end{array}$ & 4.54 & 5.06 & 6.09 & 6.64 & 7.48 & 8.07 & 8.17 & 7.99 & 6.78 & 6.63 & 5.20 & 4.49 & 6.43 \\
\hline $\begin{array}{l}\text { Direct } \\
\text { Normal } \\
\text { Insolation }\end{array}$ & 3.36 & 3.55 & 3.99 & 4.94 & 4.94 & 5.07 & 5.34 & 5.18 & 4.78 & 4.65 & 3.86 & 3.39 & 4.42 \\
\hline
\end{tabular}

The solar resource data for Fort Polk, shown in Table E-2, indicates that a flat collector tilted at $31^{\circ}$ (Tilt lat) has an average yearly solar potential of $4.95 \mathrm{kWh}$ solar $/ \mathrm{m}^{2} /$ day. A dual-axis tracking $\mathrm{PV}$ array will receive $6.43 \mathrm{kWh}_{\text {solar }} / \mathrm{m}^{2} /$ day of incident solar radiation. Figure E-7 shows this incident solar radiation on a flat roof surface $\left(0^{\circ}\right.$ tilt $)$, a fixed array (latitude tilt), a dual-axis tracking array, and a wall-mounted system $\left(90^{\circ}\right.$ tilt $)$ at Fort Polk. 


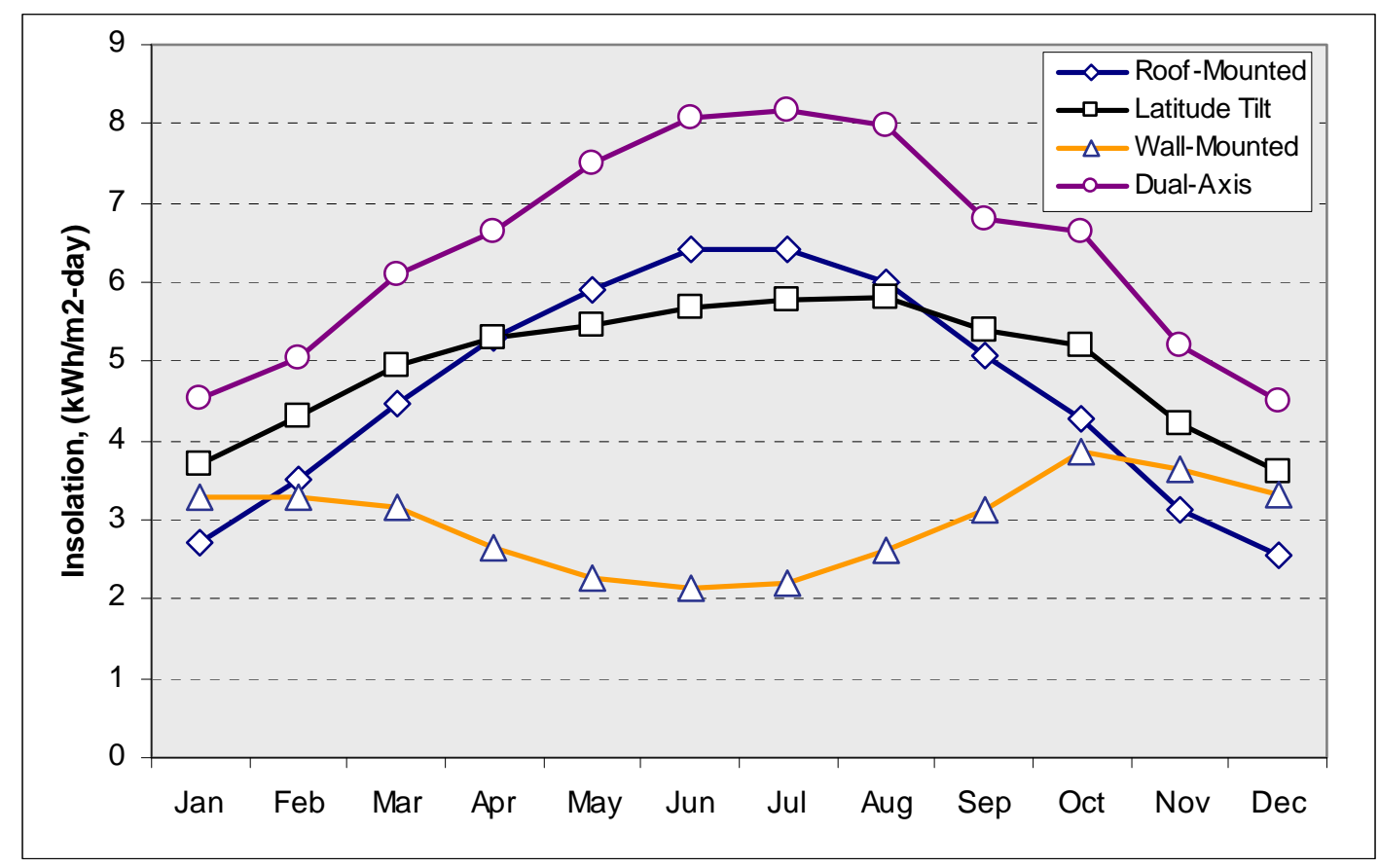

Figure E-5: Average Daily Insolation at Fort Polk

\section{Siting Considerations for PV Arrays}

Compared to most renewable energy technologies, PV panels have a fair degree of siting flexibility. As previously mentioned, an array can be mounted on the ground or upon existing buildings and structures. A potential site needs to be free of any objects, such as trees or buildings that may cast a shadow on the array. Also, the system will require an inverter to convert the DC power output into AC power. Inverters can be located indoors or outdoors, although indoor locations will provide more shelter and help ensure inverter longevity and performance. For projects larger than $25 \mathrm{~kW}$, multiple inverters are used to optimize the system's efficiency as well as provide redundancy. If any projects of this scale were considered, space would need to be secured for the inverter bank.

A typical 1-kW PV array may range in size from 8 to $9 \mathrm{~m}^{2}$; however, a larger array requires access space as well as spacing between the rows of panels to avoid self-shading and will subsequently require a greater amount of space per installed $\mathrm{kW}$. For example, a 1-MW array would likely require three to four acres. Panels mounted on slanted roofs can usually be more tightly grouped because of a decrease in self-shading potential. In addition, large arrays can produce considerable amounts of energy and require siting near existing high-voltage power lines.

Roof-integrated PV systems are ideal when there is only a minimal amount of available ground space or when a building's roof is in need of replacement. Although roof-sited PV systems frequently require $\mathrm{PV}$ panels to be installed at non-optimized angles because of roof slopes and orientations, roof-integrated PV can be an attractive option because of its relatively low cost and its capability to securely generate energy for mission-critical buildings. 
Fort Polk appears to have some open space for ground-mounted arrays. This analysis focused on displacing electricity from the northern portion of the Fort because this electricity is more expensive, and the average load on the north post is large enough to support a 1-MW PV array. Possible sites in the northern portion of Fort Polk that appear to have sufficient open space and are relativity free from shading include:

- Near the 34.5-kV line along Entrance Road

- Near the 34.5-kV line close to the water towers at the intersection of Entrance Road and Orlando Street

- Near the 34.5-kV line in the open field between North Loop and South Loop.

There are additional spaces spread throughout Fort Polk that are also near high-voltage lines. The terrain is generally flat and would require minimal grading, but may require tree removal. The primary disadvantages of these areas are their distance from the main post and existing highvoltage power lines.

\section{Findings: Solar Electric Production}

A flat collector tilted at an angle equal to the latitude has an average yearly solar potential of $4.95 \mathrm{kWh}_{\text {solar }} / \mathrm{m}^{2} /$ day. Solar conversion can be an inefficient process; typical PV cells have a conversion efficiency ranging from $10 \%$ to $20 \%$. Whereas solar potential is expressed in $\mathrm{kWh}_{\text {solar }} / \mathrm{m}^{2}$, PV array production is generally expressed as annual energy produced per rated $1 \mathrm{~kW}$ of PV array. Taking into account the annual solar potential and the efficiency of a typical PV system, each fixed-angle, latitude-tilted $\mathrm{kW}$ of installed PV would be expected to produce $1,367 \mathrm{kWh}_{\text {electric. }}$ The system would have a capacity factor of $16.6 \%$.

An axis-tracking PV array can produce $30 \%$ to $40 \%$ more energy than a stationary PV array, resulting in a higher output per unit surface area, and has a much flatter energy output profile during the day. The tracking racks increase the cost of installation by approximately $\$ 1$ to $\$ 2$ per installed watt. An axis-tracking array would produce $1,879 \mathrm{kWh}_{\text {electric }}$ annually per $1 \mathrm{~kW}$ of installed PV capacity. The system would have a capacity factor of $21.5 \%$.

Building-integrated solar systems should be considered for new construction and major renovations where cost savings can be leveraged. An integrated roof-membrane PV product installed on a flat roof would be expected to produce $1,422 \mathrm{kWh}_{\text {electric }}$ annually per $1 \mathrm{~kW}$ of installed capacity. The system would have a capacity factor of $16.2 \%$. Satellite imagery shows that the five largest viable roofs on post have approximately 10,800 square meters of open roof area that could host approximately $405 \mathrm{~kW}$ of integrated roof-membrane PV material, which would produce approximately $575 \mathrm{MWh}_{\text {electric }}$ annually.

Table E-2 lists the five large, flat (or nearly flat) building rooftops considered in this study. It was assumed that only $50 \%$ of the rooftop space would be available for PV modules because of commonly encountered roof obstructions such as HVAC systems or vents, the need to preserve access paths across the roof, and shading from nearby buildings, trees, and parapet walls. 
Table E-2: Roof-Integrated Membrane PV Analysis at Fort Polk

\begin{tabular}{|c|c|c|c||}
\hline $\begin{array}{c}\text { Building } \\
\text { Number }\end{array}$ & $\begin{array}{c}\text { Net Roof Area } \\
\left(\mathbf{m}^{\mathbf{2}} \mathbf{)}\right.\end{array}$ & $\begin{array}{c}\text { Potential Installed } \\
\text { Capacity (kW) }\end{array}$ & $\begin{array}{c}\text { Energy Output } \\
(\mathbf{M W h} / \mathbf{y})\end{array}$ \\
\hline $\mathbf{8 6 6 1}$ & 4,550 & 170 & 242 \\
\hline $\mathbf{8 5 5 3}$ & 2,360 & 90 & 128 \\
\hline $\mathbf{8 4 6 6}$ & 1,610 & 60 & 85 \\
\hline $\mathbf{7 6 7 9}$ & 1,500 & 55 & 78 \\
\hline $\mathbf{8 2 1 3}{ }^{*}$ & 780 & 30 & 42 \\
\hline Total & $\mathbf{1 0 , 8 0 0}$ & $\mathbf{4 0 5}$ & $\mathbf{5 7 5}$ \\
\hline
\end{tabular}

*Building 8213 is identical to 10 other buildings in the immediate proximity. An array could span all these roofs and use a central inverter cluster.

A summary of the solar electric production can be found in Table E-3.

Table E-3: Solar Electric Production by System Type at Fort Polk

\begin{tabular}{|c|c|c|c|c||}
\hline System Type & $\begin{array}{c}\text { Assumed } \\
\text { PV Module } \\
\text { Efficiency }\end{array}$ & $\begin{array}{c}\text { Solar } \\
\text { Insolation } \\
\mathbf{( k W h}_{\left.\text {solar } / \mathbf{m}^{2} / \mathbf{l y r}\right)}\end{array}$ & $\begin{array}{c}\text { Electric } \\
\text { Production } \\
\mathbf{( k W h}_{\text {electric/yr) }}\end{array}$ & $\begin{array}{c}\text { Capacity } \\
\text { Factor }\end{array}$ \\
\hline $\begin{array}{c}1 \mathrm{~kW} \text { South-Facing, } \\
\text { Latitude Tilt }\end{array}$ & $11.00 \%$ & 4.95 & 1,367 & $16.6 \%$ \\
\hline $\begin{array}{c}1 \mathrm{~kW} \text { Integrated Roof } \\
\text { Membrane }\end{array}$ & $7.60 \%$ & 4.65 & 1,422 & $16.2 \%$ \\
\hline $\begin{array}{c}1 \text { kW Dual-Axis } \\
\text { Tracking }\end{array}$ & $11.00 \%$ & 6.43 & 1,879 & $21.5 \%$ \\
\hline
\end{tabular}

\section{Findings: Solar Project Economics}

Based on current average solar system costs and the projected performance for the various solar system configurations, life-cycle costs were developed for solar technologies under two funding scenarios, as described in Appendix A:

- Appropriated, using Energy Conservation Investment Program (ECIP) funds, and

- Third-party financing via an independent power producer (IPP).

Building-integrated PV can be developed by a third party to take advantage of government incentives.

Solar arrays are not capable of providing baseload power because of their intermittent nature. Because the energy production of a PV solar system peaks during the daytime and is larger in the summer than in the winter, the energy produced by a solar system would vary over the year. Fort Polk has two primary meters that serves different portions of the fort. The north meter's energy rate is slightly more expensive than the south meter, and the load is large enough to support a large solar array. Consequently, the rate used for this analysis is $6.87 \phi / \mathrm{kWh}$.

Despite the moderately strong solar resource, none of the solar systems are cost-effective at this time. The combination of low-cost energy and high system capital costs is the principle barrier 
to economic solar power generation. The SIR and simple payback for the ECIP scenario, the cost of electricity at a 10\% IRR for the third-party financing scenario, and the assumed system costs are shown in Table E-4 for each technology. This analysis assumed a 3.0\% real discount rate and a $1.2 \%$ general inflation rate. The 3.0\% discount rate is a typical value used for net present value (NPV) calculations while the $1.2 \%$ general inflation rate is based upon national statistics.

Table E-4: Economic Results for Solar Technologies at Fort Polk

\begin{tabular}{|l|c|c|c||}
\hline & $\begin{array}{c}\text { Ground-Mounted } \\
\text { Fixed-Tilt PV }\end{array}$ & $\begin{array}{c}\text { Ground-Mounted } \\
\text { Axis-Tracking PV }\end{array}$ & $\begin{array}{c}\text { Building-Integrated } \\
\text { Roof-Mounted PV }\end{array}$ \\
\hline $\begin{array}{l}\text { Equipment Cost } \\
\text { Assumptions (\$/kW) }\end{array}$ & $\$ 4,500$ & $\$ 6,500$ & $\$ 3,750$ \\
\hline SIR & 0.30 & 0.29 & 0.37 \\
\hline Simple Payback (yrs) & 46 & 50 & 40 \\
\hline $\begin{array}{l}\text { Cost of Electricity at } \\
\text { 10\% IRR (\$/kWh) }\end{array}$ & 33.4 & 36.9 & 28.7 \\
\hline $\begin{array}{l}\text { Variable O\&M } \\
\text { (\$/kWh) }\end{array}$ & 0.0 & 0.0 & 0.0 \\
\hline Fixed O\&M (\$/net kW) & $\$ 12$ & $\$ 12$ & $\$ 12$ \\
\hline
\end{tabular}

\section{Solar: Next Steps}

Fort Polk has a moderate solar energy resource. Unfortunately, present project capital costs and current electric rates do not show independent solar energy projects to be cost-effective at this time. Future rate increases and an introduction of a renewable portfolio standard may eventually allow PV to be cost-effective. Fort Polk should continue to monitor the market conditions affecting solar energy. Advances in PV technology are expected to produce less expensive solar cells, although rising demand may negate some of the potential price drop. Probably the most important factor in making solar electric work at a Federal installation is identifying key partners - a private developer, a utility, or both - that can provide funding, capture tax incentives, purchase or market RECs, enter into PPAs, and provide other project support.

\section{Solar Sources of Information}

DOE-Department of Energy. 1997. "Renewable Energy Technology Characterizations December 1997 - Solar Parabolic Trough." Accessed November 2008 at http://www1.eere.energy.gov/ba/pba/pdfs/solar_trough.pdf.

DOE_Department of Energy. 1997. "Renewable Energy Technology Characterizations December 1997 - Solar Power Tower." Accessed November 2008 at http://www1.eere.energy.gov/ba/pba/pdfs/solar_tower.pdf.

DOE_Department of Energy. 1997. "Renewable Energy Technology Characterizations December 1997 - Solar Dish Engine.” Accessed November 2008 at http://www1.eere.energy.gov/ba/pba/pdfs/solar_dish.pdf.

Emerging Energy Research, LTD. 2007. "Global Concentrating Solar Power Markets and Strategies, 2007-2020.” Cambridge, Massachusetts. 
LBNL_Lawrence Berkeley National Laboratory. 2009. "Tracing the Sun: The Installed Cost of Photovoltaics in the U.S. from 1998-2007.” Berkeley, California.

Minister of Natural Resources Canada. 1997-2008. RETscreen International Software Package, Clean Energy Decision Support Centre. Accessed at http://www.retscreen.net.

Sargent \& Lundy Consulting Group. 2003. "Assessment of Parabolic Trough and Power Tower Solar Technology Cost and Performance Forecasts.” Chicago, Illinois.

Stoddard L, J Abiecunas, and R O'Connell. 2006. "Economic, Energy, and Environmental Benefits of Concentrating Solar Power in California." NREL/SR-550-39291, Black \& Veatch. National Renewable Energy Laboratory. Overland Park, Kansas. 


\section{APPENDIX F}

\section{Analysis of Wind Opportunities}




\section{Appendix F: Analysis of Wind Opportunities}

\section{Wind Technology}

There is a vast wind resource in the United States. The American Wind Energy Association states that domestic wind resources, which are economically feasible in at least 46 states, could theoretically supply all of the nation's electricity needs (AWEA 2007). At the current time, however, less than $2 \%$ of the nation's power is generated from wind, though electricity generation from wind power projects continues to increase. In 2008, wind power projects accounted for $42 \%$ of all the new generating capacity installed in the United States, up from $2 \%$ of installed capacity in 2004 (AWEA 2009).

Wind projects, often referred to as wind farms, can be categorized by scale. Large, utility-scale projects tend to be $50 \mathrm{MW}$ and above, with the world's largest single wind farm being in Texas at over $700 \mathrm{MW}$. Smaller-sized projects (fewer than $50 \mathrm{MW}$ ) are often referred to as community wind projects or distributed generation (DG) projects. Community wind projects involve local ownership structures, often with corporate partners taking advantage of the federal production tax credit. DG projects are designed to offset the owner's retail electricity purchases by producing power that is used onsite, with any surplus sold to a commercial utility.

Wind turbines come in many different sizes and configurations. Wind turbines in the United States generally employ the Danish configuration - a horizontal-axis, three-bladed rotor, an upwind orientation, and an active yaw system to keep the rotor oriented into the wind.

Utility-scale turbines for bulk power production tend to be $660 \mathrm{~kW}$ to $3 \mathrm{MW}$ in size. Hub heights can range from 50 meters (164 feet) to 100 meters (328 feet). Industrial turbines for consumer and remote grid production are found in the range of $50 \mathrm{~kW}$ to $250 \mathrm{~kW}$. Hub heights range between 25 meters $(80$ feet) and 40 meters (131 feet). Residential-scale wind turbines are used for remote power, battery charging, or net-metering generation. These turbines tend to be 400 watts to $50 \mathrm{~kW}$. For turbines greater than $1 \mathrm{~kW}$, the hub heights range from 12 meters (40 feet) to 36 meters (120 feet).

The land required for a single utility-scale wind turbine is typically 3 acres, including access roads, turbine base, and other equipment. A wind turbine located on a ridgeline in hilly terrain will require less area than one on flat land, as little as 2 acres per MW. The proper spacing of turbines is essential to reduce wake interference and optimize the wind resource. In open flat terrain, a utility-scale wind plant will require a buffer space of about 60 acres per MW of installed capacity.

Although more difficult to finance and lacking in economies of scale, smaller-sized wind generation projects offer some potential benefits over large-scale wind farms:

$\checkmark$ A smaller project is often easier to permit and may be less likely to interfere with other land uses (including military missions).

$\checkmark$ Onsite power generation that is integrated into the site electrical system provides energy security.

$\checkmark \quad$ It may be possible to avoid building a costly substation if a suitably sized power interconnection is located near a promising site for wind turbines. 


\section{Wind Analysis Approach}

\section{DoD Assessment Approach}

The DoD Renewables Study relied upon wind resource maps developed by the National Renewable Energy Laboratory (NREL), maps developed by independent companies, and PNNL's Wind Energy Resource Atlas of the United States to identify the installations with the best potential for commercialscale wind farms. The DoD analysis used the highest resolution map available for each state to quantify the wind resource on the military land in that state. Over 70 Army and Air Force installations were reviewed with respect to both wind resource and compatibility with the installation's mission. About 20 installations with potential for projects were selected for follow-on detailed assessments. Fort Polk was not included in this study.

\section{Updated Wind Analysis Approach}

For this updated analysis, PNNL used the following approach to analyze the economic potential for wind energy at Fort Polk. More detail on the financing scenarios, generic analytic approach, and economic and other parameters used in this analysis are documented in Appendix A of this report.

(1) Wind resource maps were analyzed.

(2) Existing onsite interconnection and transmission capacity and availability were evaluated.

(3) Local wind developer activity in the area was surveyed to assess potential interest in developing projects.

(4) Available turbine models were evaluated to establish cost and performance parameters.

(5) The total project cost was estimated, including project development, generation equipment, balance of plant construction, interconnection and transmission, operation and maintenance $(\mathrm{O} \& \mathrm{M})$, taxes, and tax credits and other policy incentives.

(6) Economic feasibility was determined using different financing scenarios: independent power producer (IPP) and Energy Conservation Investment Program (ECIP).

(7) Project feasibility was determined and next steps recommended.

\section{Wind Resource Characterization}

According to industry standards developed as part of the Wind Energy Resource Atlas of the United States, there are seven main classes of wind power, as shown in Table F-1. 
Table F-1: Classes of Wind Power Density at 50 Meters

\begin{tabular}{||c|c|c||}
\hline $\begin{array}{c}\text { Wind } \\
\text { Power } \\
\text { Class }\end{array}$ & $\begin{array}{c}\text { Wind Power } \\
\text { Density, W/m }\end{array}$ & Speed, m/s (mph) \\
\hline $\mathbf{1}$ & $<200$ & $<5.6(12.5)$ \\
\hline $\mathbf{2}$ & $200-300$ & $5.6(12.5)-6.4(14.3)$ \\
\hline $\mathbf{3}$ & $300-400$ & $6.4(14.3)-7.0(15.7)$ \\
\hline $\mathbf{4}$ & $400-500$ & $7.0(15.7)-7.5(16.8)$ \\
\hline $\mathbf{5}$ & $500-600$ & $7.5(16.8)-8.0(17.9)$ \\
\hline $\mathbf{6}$ & $600-800$ & $8.0(17.9)-8.8(19.7)$ \\
\hline $\mathbf{7}$ & $>800$ & $>8.8(19.7)$ \\
\hline
\end{tabular}

A strong Class 3 resource, or preferably a Class 4, is generally required to achieve an economic project on a large, commercial scale. According to the Louisiana State Wind Resource Map (NREL 2010), Fort Polk has an average wind resource of $4.5 \mathrm{~m} / \mathrm{s}$ at $80 \mathrm{~m}$, which translates to a Class 1 wind resource. A Class 1 wind resource is not sufficient to support a large-scale wind energy project.

The FirstLook mapping tool from 3TIER was also used to determine an average annual wind speed estimate for Fort Polk. At 80 meters above ground, a typical hub height for commercial-scale turbines, the highest average annual wind speed found on site is approximately $4.1 \mathrm{~m} / \mathrm{s}$ (3TIER 2010), as shown in Figure F-1.

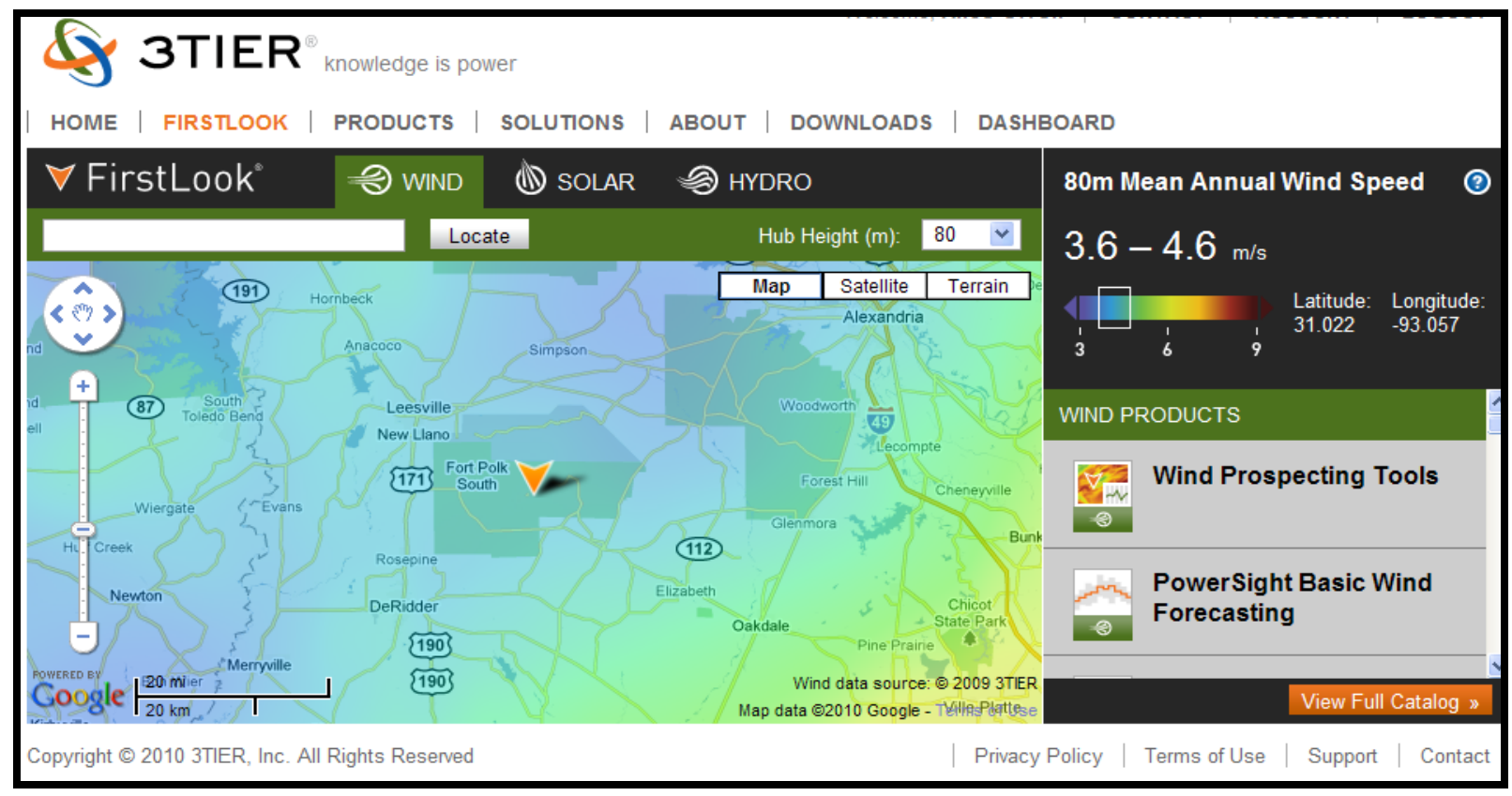

Figure F-1: Highest Wind Speed on Fort Polk

The National Aeronautics and Space Administration's (NASA) Langley Research Center Atmospheric Science Data Center was used as a reference comparison for Fort Polk's average wind speed. NASA Surface Meteorology and Solar Energy (SSE) provides data on a $1^{\circ}$ by $1^{\circ}$ grid system, based on wind 
speed data over a 10-year period from July 1983 to June 1993. According to this source, the annual average wind speed in the Fort Polk area is $3.6 \mathrm{~m} / \mathrm{s}$ at 50 meters (NASA 2008).

Table F-2 summarizes Fort Polk’s wind resource.

Table F- 2: Summary of Wind Resource Data

\begin{tabular}{|c|c|c|}
\hline Location & Source & Wind Speed \\
\hline \multirow{3}{*}{ Fort Polk, Louisiana } & Louisiana State Wind Resource Map & $4.5 \mathrm{~m} / \mathrm{s}$ at $80 \mathrm{~m}$ \\
\cline { 2 - 3 } & FirstLook tool from 3TIER & $\begin{array}{c}3.6-4.6 \mathrm{~m} / \mathrm{s} \text { at } 80 \mathrm{~m}, \\
3.3-4.2 \mathrm{~m} / \mathrm{s} \text { at } 50 \mathrm{~m}\end{array}$ \\
\cline { 2 - 3 } & NASA SSE data & $3.6 \mathrm{~m} / \mathrm{s}$ at $50 \mathrm{~m}$ \\
\hline
\end{tabular}

\section{Siting Considerations}

The primary siting consideration for wind projects is transmission availability and the capacity of those lines. Projects need to be located within approximately 1 mile of existing transmission lines, or new lines will need to be constructed at considerable cost.

This analysis does not include any transmission costs and assumes that existing transmission lines are available to transmit power without substantial additional investment. It is also assumed that an onsite wind project would not trigger new standby or other fees from the local utility. But because wind is intermittent, the utility may have interconnection requirements to ensure grid stability and to ensure that there is reliable power for the installation.

Another consideration is potential interference with airport operations. The Federal Aviation Administration (FAA) requires notice of proposed construction for a project that meets certain criteria so that it can determine if there would be adverse impacts to air navigation safety. One of the triggering criteria is whether the project would be located within 20,000 feet (3.8 miles) or less of an existing public or military airport. When selecting an area for a wind project, it would be best to avoid this potential interference issue by locating the project outside of the 20,000-foot range. This concern would need to be carefully considered for any wind project developed onsite.

An additional FAA criterion triggering the notice of proposed construction is any construction or alteration of more than 200 feet (61 meters) in height above ground level. This criterion applies regardless of the distance from the proposed project to an airport. A determination of "No Hazard to Air Navigation" must be obtained from the FAA before constructing a wind project.

\section{Wind: Economic and Other Analysis Parameters}

This assessment considered the current federal wind incentives: a $2.1 \phi / \mathrm{kWh}$ renewable energy production tax credit (PTC) and 5-year accelerated depreciation. State-specific incentives for Louisiana are discussed in Appendix A.

During the original DoD renewable energy assessment in 2005, the installed cost of capital was approximately $\$ 1,400 / \mathrm{kW}$; at the current time, prices range from $\$ 1,700$ to $\$ 2,600 / \mathrm{kW}$ because of high demand and increased costs for components. The capital cost was assumed to be $\$ 2,256 / \mathrm{kW}$ (including incentives) for this economic assessment. Further details on the analysis methodology and the economic 
and incentive parameters are documented in Appendix A, and the assumptions used are listed in Table F-3.

Table F-3: Performance, Cost, and Economic Characteristics

\begin{tabular}{|l|l|}
\hline Location & Fort Polk, Louisiana \\
\hline Conditions & $\begin{array}{l}\text { Standard: } 1.225 \mathrm{~kg} / \mathrm{m}^{3} \text { density, } \\
0^{\circ} \mathrm{F}, 0 \mathrm{ft} \text { elevation }\end{array}$ \\
\hline Assumed Average Wind Speed & $4.1 \mathrm{~m} / \mathrm{s}$ at $80 \mathrm{~m}$ \\
\hline Net Capacity Factor & $7.4 \%$ \\
\hline Turbine Type & $\begin{array}{l}1.5 \mathrm{MW}, 77 \mathrm{~m} \text { rotor, } 80 \mathrm{~m} \text { hub } \\
\text { height }\end{array}$ \\
\hline Project Size & 1 turbine, $1.5 \mathrm{MW}$ total \\
\hline $\begin{array}{l}\text { Estimated Net Annual Energy } \\
\text { Production }\end{array}$ & $970,583 \mathrm{kWh} / \mathrm{yr}$ \\
\hline Energy Charge & $6.87 \$ / \mathrm{kWh}$ \\
\hline Total Capital Cost & $\$ 2,256 / \mathrm{kW}$ \\
\hline Fixed O\&M Cost & $\$ 60 / \mathrm{kW}$ \\
\hline 5-year accelerated depreciation & Included \\
\hline Federal 2.1\$/kWh PTC & Included \\
\hline RECs & Not Included \\
\hline Transmission Costs & Not Included \\
\hline
\end{tabular}

\section{Findings: Wind}

The various energy cost scenarios were evaluated for ECIP eligibility and IPP project potential. To qualify for ECIP funding, a project must achieve a savings-to-investment ratio (SIR) of 1.0, and its payback is also examined. For the IPP evaluation, the commercial cost of energy was calculated to obtain an internal rate of return (IRR) of $10 \%$. This was used as the minimum IRR required to attract the interest of a wind power project developer. Table F-4 lists the results of these analyses.

Table F-4: Economic Assessment of Wind Power

\begin{tabular}{|c|c|c|c|c||}
\hline $\begin{array}{c}\text { Financing } \\
\text { Scenario }\end{array}$ & $\begin{array}{c}\text { Energy } \\
\text { Cost } \\
\mathbf{( \$ / k W h )}\end{array}$ & IRR & ECIP SIR & $\begin{array}{c}\text { Simple } \\
\text { Payback } \\
\text { (years) }\end{array}$ \\
\hline ECIP & 6.87 & $\mathrm{n} / \mathrm{a}$ & negative & 155 \\
\hline IPP & 56.98 & $10 \%$ & $\mathrm{n} / \mathrm{a}$ & $\mathrm{n} / \mathrm{a}$ \\
\hline
\end{tabular}

\section{Wind: Next Steps}

As a result of the poor wind resource and unfavorable economics, Fort Polk should not pursue a wind power project.

\section{Wind Sources of Information}

3TIER. 2010. FirstLook. Accessed March 2010 at http://www.3tier.com/firstlook/. 
AWEA - American Wind Energy Association. 2007. "Wind Power Today." Accessed at http://www.awea.org/pubs/factsheets/WindPowerToday_2007.pdf.

AWEA - American Wind Energy Association. 2009. "Wind Power Outlook." Accessed at http://www.awea.org/pubs/documents/Outlook_2009.pdf.

NREL - National Renewable Energy Laboratory. 2010. Louisiana Annual Average Wind Speed at 80 m. Accessed March 2010 at http://www.windpoweringamerica.gov/images/windmaps/la 80m.jpg.

FAA - Federal Aviation Administration. 2007. Advisory Circular (AC 70/7460-1K) Obstruction Marking and Lighting. Effective: February 2, 2007. Accessed at

http://www.airweb.faa.gov/Regulatory and Guidance Library/rgAdvisoryCircular.nsf/0/b993dcdfc $37 \mathrm{fc}$ dc486257251005c4e21/\$FILE/AC70_7460_1K.pdf.

Global Energy Concepts, LLC. 2004. U.S. Department of Defense Renewable Energy Assessment: Report of Wind Energy Potential On and Near Military Installations. Prepared for NREL. Subcontract No: LAM-3-32257-01.

NASA Langley Research Center. 2009. Surface meteorology and Solar Energy. Atmospheric Science Data Center. Accessed October 2009 at http://eosweb.larc.nasa.gov/sse/ (last updated August 28, 2009).

Pacific Northwest Laboratory. 1986. Wind Energy Resource Atlas of the United States. Solar Technical Information Program \& Solar Energy Research Institute. Golden, Colorado. Accessed at http://rredc.nrel.gov/wind/pubs/atlas/atlas index.html. 


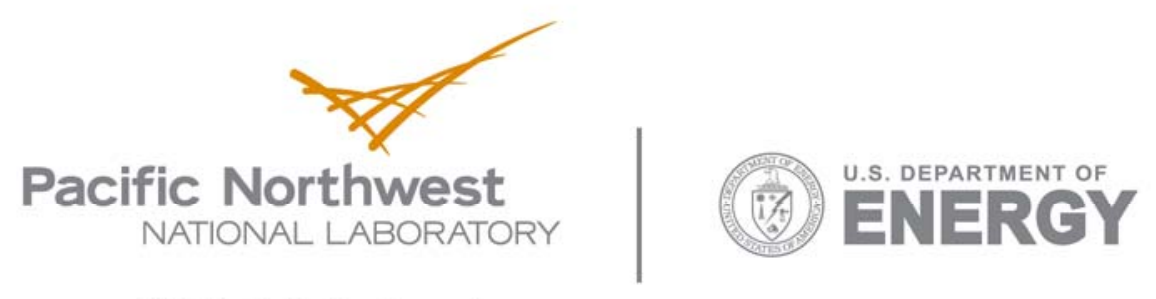

902 Battelle Boulevard

P.O. Box 999

Richland, WA 99352

1-888-375-PNNL (7665)

www.pnl.gov 